\title{
El campesinado andalusí del secano manchego (s. XI). Primera campaña de excavaciones en la alquería de La Graja (Higueruela, Albacete)
}

\author{
The andalusí peasants of dryland in La Mancha (S. XI). First excavation \\ campaign in the qarya de La Graja (Higueruela, Albacete)
}

Pedro Jiménez Castillo, José Luis Simón García², José María Moreno Narganes $^{3}$

Recibido: 19/05/21 Aprobado: 28/06/21 Publicado: $8 / 11 / 2021$

\begin{abstract}
RESUMEN
En este trabajo analizaremos el registro arqueológico que ha proporcionado la primera campaña de excavaciones en la alquería de La Graja (Higueruela, Albacete) durante el año 2020, a partir del cual pretendemos obtener datos que nos permitan aproximarnos al poblamiento andalusí en las comarcas sudorientales de La Mancha. La excavación arqueológica complementa la información aportada por las prospecciones realizadas en el territorio castral de Chinchilla en época andalusí y en el Corredor de Almansa, un área de secano donde se documenta durante el siglo XI una intensa ocupación articulada en un número considerable de alquerías (qurā) en llano. Dicha intervención nos ha permitido documentar una arquitectura doméstica modesta y funcional caracterizada por emplear los recursos del entorno (piedra, tierra y madera), sin elementos decorativos ni materiales elaborados como el ladrillo, y cuyos espacios carecen de la especialización funcional propia de las casas urbanas.
\end{abstract}

Palabras clave: Al-Andalus, época taifa, alquerías, ganadería, agricultura de secano.

\section{INTRODUCCIÓN}

Las prospecciones sistemáticas de campo que llevamos a cabo a lo largo de las dos últimas décadas en el sector sudoriental de La Mancha, actual provincia de Albacete, que en época andalusí constituía el iqlīm o territorio

\section{ABSTRACT}

In this paper we will analyse the archaeological register provided by the first excavation campaign in the village of La Graja (Higueruela, Albacete) during the year 2020, from which we intend to obtain data that will provide us with a first knowledge about the Andalusian settlement in the south-eastern regions of La Mancha. The archaeological excavation complements the information provided by the surveys carried out in the castral territory of Chinchilla in the Andalusian period and in the Corredor de Almansa, an area of dry land where an intense occupation is documented during the $11^{\text {th }}$ century articulated in a considerable number of villages (qurā) on the plain. This intervention has documented a modest and functional domestic architecture characterised by the use of the resources of the environment (stone, earth and wood), without decorative elements or elaborate materials such as brick, and whose spaces lack the functional specialisation typical of urban houses.

Keywords: Al-Andalus, Taifa period, villages, rural settlement, livestock, dry farming

dependiente de la madīna de Chinchilla, nos mostraron una intensa ocupación de alquerías (pl. qurā, sing. qarya) (Fig. 1) que no responden al arquetipo más habitual de estos asentamientos, pues se hallaban mayoritariamente en llano y en contextos claramente de secano. Su buen estado de conservación permitió en

1. Escuela de Estudios Árabes (CSIC); pedro@eea.csic.es https://orcid.org/0000-0002-6012-4414

2. Universidad de Alicante; jolusiga1960@gmail.com http://orcid.org/0000-0002-5118-8790

3. Universidad de Alicante; jmmoreno@ua.es https://orcid.org/0000-0003-1345-7037

Cómo citar: Jiménez Castillo, P., Simón García, J. L., Moreno Narganes, J. M. (2021): El campesinado andalusí del secano manchego (s. XI). Primera campaña de excavaciones en la alquería de La Graja (Higueruela, Albacete). Arqueología y Territorio Medieval, 28. e6360. https://doi.org/10.17561/aytm.v28.6360 


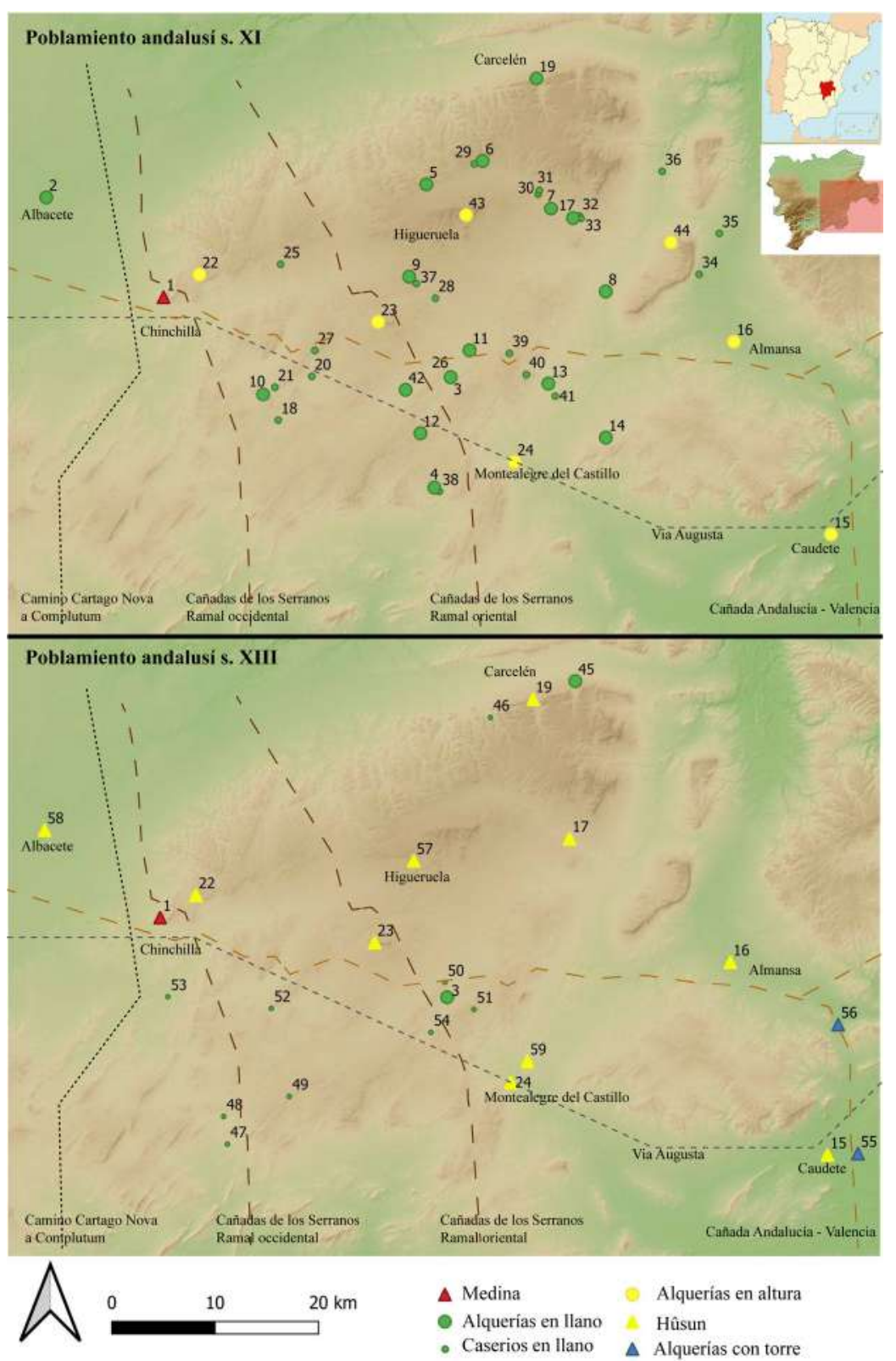

Fig. 1. Evolución del poblamiento en el territorio de Chinchilla (SS. XI /XIII).

1- Castillo y medina de Chinchilla. 2- San Antón (Albacete). 3- Los Villares del Bachiller. 4- Prados del Olmillo. 5- La Graja (Higueruela). 6- Malefatón. 7- Tobillos. 8- El Carrascal. 9- El Villar u Hoya Honda. 10-Peñicas o Malas Tardes. 11- La Toyosa. 12- La Carrasquilla. 13-Bancal de las Tinajas. 14- Pozo de la Higuera. 15-Castillo de Caudete. 16-Castillo de Almansa. 17-Castillo de San Gregorio. 18-Villora. 19-Los Torrejones. 20-Casa de las Palomas. 21-Los Villares de Horna. 22-Fortaleza. 23-Cerro de las Tinajas de Mompichel. 24- Torre de Pechín - Los Castellares. 25- Prado Viejo. 26- El Boquerón. 27- Rincón del Cerro de la Fuente del Cuervo. 28-Corrales de Casa Guarda. 29- Casa de la Zorra. 30- Casa del Sol. 31- Las Fuentes. 32-Loma de la Vega. 33-Bancal del Reviejo. 34- Pozo de Egea. 35- Hoya Marín. 36- Las Torcas. 37- Los Pocicos. 38-El Olmillo de Abajo. 39-Fuente Somera. 40-El Chisnar. 41- Casa de Dona Juliana. 42-Corral Rubio. 43- Los Castillicos o La Rambla. 44- El Castellar de Meca. 45-Cerro de Dolonche. 46-Cerro Fino. 47-Ladera Oriental del Almorchón. 48- Mezquitillas II. 49- Morra de Montesinos. 50- El Bachiller. 51- Fuentechilla. 52- Aldea de Horna. 53- San Cristóbal. 54- Morra de la Cueva de la Paja o Aguaza I y II. 55- Torre de Bogarra. 56- Torre de Burharón. 57- Castillo de Higueruela. 58Castillo de Albacete y Cerro de San Juan. 59- Castillo de Montealegre del Castillo. 
muchos casos levantar planimetrías generales en las que se pueden identificar los perímetros de manzanas y edificios, e incluso a veces la distribución interna de estos últimos, gracias a todo lo cual sabemos que carecían de elementos de defensa comunitarios y que debieron de estar habitadas por un campesinado humilde, a juzgar por la modestia de la arquitectura y de los ajuares domésticos recuperados en superficie. Después de varios estudios basados en dichas prospecciones, en el año 2020 llevamos a cabo la primera campaña de excavaciones en una de estas alquerías, la de La Graja (Higueruela), lo que nos ha aportado información relevante que confirma algunas de las hipótesis previas y permite plantear otras nuevas, de todo lo cual pretendemos dar noticia en el presente artículo ${ }^{4}$.

Durante las tres últimas décadas han proliferado los estudios relativos al poblamiento rural andalusí, así como a los espacios agrícolas y los sistemas hidráulicos asociados, que se han basado fundamentalmente en la arqueología espacial y en las herramientas propias de esta disciplina: prospección, toponimia, fotografía aérea, etc., mientras que apenas se han beneficiado de unas fuentes escritas exiguas, dispersas y limitadas. Por razones metodológicas y también por la elección de unos objetivos científicos preferentemente enfocados a los medios de producción, estos trabajos han prestado poca atención a los espacios de habitación, de manera que apenas se han llevado a cabo análisis urbanísticos y arquitectónicos de los asentamientos rurales basados en excavaciones arqueológicas. Por ello persisten muchos interrogantes acerca de aspectos internos de estas comunidades campesinas que en los textos son muy esquivos o directamente imperceptibles, pero sobre los que se puede obtener información valiosa mediante la arqueología; como el consumo, el comercio, el trabajo, la organización familiar o la estratificación interna. Además, resulta extremadamente delicado comparar los resultados de las pocas excavaciones que hasta el momento se han llevado a cabo en asentamientos rurales cuando estos son muy dispares en aspectos clave como el tiempo y el espacio; pues entre algunos yacimientos pueden mediar varios siglos y darse profundas diferencias derivadas de las características geográficas particulares del emplazamiento de cada uno.

El interés científico por el mundo rural andalusí arranca de la obra de Pierre Guichard (1976, 1990), quien planteó a partir de las fuentes escritas algunos de los problemas históricos fundamentales, como el supuesto carácter tribal de estas comunidades y su amplia extensión geográfica y perduración temporal; su resiliencia frente al estado islámico; el carácter mayoritariamente colectivo de la producción o la uniformidad de su organización interna, entre otros. Bajo la influencia de la obra del desaparecido hispanista francés, se desarrollaron los primeros estudios de arqueología extensiva que trataban de dar respuesta a estas cuestiones, casi todos de carácter extensivo, a cargo del propio Guichard y de sus colegas de la Casa de Velázquez (CRESSIER, 1984; BAZZANA, CRESSIER, GUICHARD, 1988; BAZZANA, 1992), así como de Miquel Barceló (1988) y su escuela, en este caso a partir de una orientación marxista cuyos fundamentos dejó pormenorizadamente expuestos 5 .

Precisamente, la determinación teórica por parte de Barceló y sus discípulos de la lógica que rige la formación de los sistemas de irrigación y las pautas que condicionan su desarrollo, es lo que ha permitido el estudio de los espacios hidráulicos que han llegado hasta la actualidad

\footnotetext{
4. Las excavaciones forman parte de un proyecto de investigación financiado por el Instituto de Estudios Albacetenses, con la colaboración del Ayuntamiento de Higueruela y el apoyo de la Fundación Iberdrola. Nuestra participación se enmarca en el proyecto ALMEDIMED “Almunias medievales en el Mediterráneo: Historia y conservación de los paisajes culturales periurbanos" (PID2019111508GB-100), del que es IP el Dr. Julio Navarro (EEA-CSIC). Cofinanciado con fondos FEDER, pertenece al Programa Estatal de Generación de Conocimiento y Fortalecimiento Científico y Tecnológico del Sistema de I+D+i, Subprograma Estatal de Generación del Conocimiento, del Ministerio de Ciencia e Innovación.

5. Para consultar las principales cuestiones que en la actualidad tiene planteada la investigación arqueológica sobre el campesinado andalusí, incluida una cuidada selección bibliográfica por temas, véase KIRCHNER, 2020.
} 
como fósiles arqueológicos de la sociedad que los diseñó y utilizó.

Por todo ello, la agricultura irrigada andalusí ha adquirido un carácter hegemónico en la historiografía que de manera errónea se ha trasladado a la historia, como hace por ejemplo Eiroa (2012: 56) al considerarla "the highest agricultural expression of Andalusian society", como si se tratara de la refinada culminación de un proceso de avance tecnológico y no de una estrategia productiva por la que optan campesinos y terratenientes en determinadas circunstancias y en unas áreas geográficas específicas. De esta manera, el regadío se ha establecido como el referente determinante a partir del cual entender las otras opciones productivas en el medio rural: los cultivos de secano, la ganadería y las diferentes maneras en que se beneficiaban las zonas incultas, actividades todas ellas que se han percibido como supeditadas o subalternas a la agricultura irrigada (TRILLO, 2004: 53-54; RETAMERO, 2011: 32).

Existe por contraste, un notable vacío historiográfico relativo al poblamiento y explotación de las tierras de secano, que se debe en parte a la dificultad que entraña el análisis de los espacios productivos medievales mediante las técnicas de la arqueología espacial en ausencia de elementos físicamente identificables, como los sistemas hidráulicos propios de la irrigación ${ }^{6}$. Pero también, y sobre todo, porque se ha considerado que el estudio del aprovechamiento económico del secano tendría un menor valor desde el punto de vista histórico para el análisis y caracterización de la sociedad andalusí, ya que esta se diferenciaría de la feudal y de la tardoantigua precisamente por la expansión de la agricultura de regadío?. Obviamente, el presente proyecto, que tiene como objeto no solo la alquería de La Graja sino un numeroso conjunto de asentamientos análogos cuya economía estaría basada esencialmente en el secano y la ganadería, pretende contribuir a mitigar esta deformación historiográfica.

Los estudios sobre la agricultura andalusí presentan otro sesgo añadido puesto que, por razones metodológicas y también por la elección de unos objetivos científicos preferentemente enfocados a los medios de producción, estos trabajos han prestado poca atención a los espacios de habitación, de manera que apenas se han llevado a cabo análisis urbanísticos y arquitectónicos de los asentamientos rurales a partir de excavaciones.

Dado que solo ocasionalmente se han efectuado análisis arqueológicos de las áreas habitadas de las alquerías, tal y como nosotros hemos emprendido en La Graja, merece la pena reseñar los ejemplos más destacados. Comenzando por época emiral, tenemos el caso de la alquería de Peñaflor, en la campiña de Jaén (SALVATIERRA, CASTILLO, 1995, 2000), cronología similar a la del asentamiento fortificado del hiṣn de Jolopos, mientras que la alquería que está en sus proximidades es del siglo XI (BERTRAND, SÁNCHEZ, 2002). Otros ejemplos los encontramos en el yacimiento de las Sillas de Marcén, en Huesca, que data de los siglos X-XI (SÉNAC et al., 2020), o el de Font Voltá (Ares del Maestrat, Castellón), del XI-XII (GONZÁLEZ, 1995). En el paraje de l'Almisserà se excavaron íntegramente tres alquerías muy próximas entre sí: Tossal (siglos XI-XII), Foietes d'Alt (siglos IX-XI) y l'Alfarella (siglos XII-XIII), así como una mezquita rural asociada a una torre y a un cementerio islámico o almacabra con 79 tumbas (GARCÍA, LLORENS, PÉREZ, 2004); además de las anteriores se han documentado otras alquerías en el sureste peninsular, como El Secanet (Orcheta, Alicante) (GARCÍA, PÉREZ, LLORENS, 2002) y La Rambleta (Crevillente, Alicante) (ESQUEMBRE et al., 2003: 62-64). En el suroeste, Alcaria Longa es un pequeño asentamiento de entre finales del siglo X y comienzos

\footnotetext{
6. Este desequilibrio entre los estudios sobre las áreas irrigadas y las de secano se manifiesta en el número de publicaciones dedicadas a unas y a otras, como se puede apreciar en el balance de H. Kirchner (2020: 467-471).

7. Por ejemplo, Jiménez Puertas y Carvajal López (2011: 57): "A lo largo del texto dedicaremos relativamente poco espacio al secano y mucho al regadío, lo que puede parecer inapropiado en un encuentro para hablar del primero”. La razón se puede resumir en que "podemos concebir la opción del regadío [andalusí] como opuesta a la opción de secano existente en la sociedad tardoantigua...".
} 
del XII próximo a Mértola (BOONE, 1992, 1993, 2009); también está situada en el Algarve oriental la alquería de Odeleite, en la que se excavó una decena de casas, que arranca a finales del s. X-comienzos del XI y se abandonó en época almohade (CARVALHO DOS SANTOS, 2006). Como ejemplos tardíos tenemos también el de Solibernat, en Lérida, que se fecha en la primera mitad del siglo XII (ROVIRA et al., 1997); de los siglos XII-XIII son las alquerías de la Villa Vieja de Calasparra (POZO, 2000) y Bofilla, en Valencia (LÓPEZ ELUM, 1994). Finalmente, el Castillejo de Los Guájares (Granada) pervivió desde época almohade hasta la nazarí (BERTRAND et al., 1990; GARCÍA PORRAS, 2001).

Por consiguiente, el interés histórico de la línea de investigación que venimos desarrollando en La Mancha sudoriental y en La Graja en concreto, se debe en gran medida a la escasez de estudios sobre la explotación y el poblamiento del campo andalusí, es decir, el espacio de secano en el que las huertas son inexistentes o irrelevantes en el conjunto de la economía campesina (SABATÉ, BRUFAL, 2011; BRUFAL, 2009). Lo mismo se puede afirmar sobre la ganadería en al-Andalus, de la que se cuenta con escasos datos y lo poco que sabemos corresponde mayoritariamente a época nazarí, es decir, a un momento tardío (CARA, 2009; MALPICA, 2012; GARCÍA-GARCÍA, MORENO-GARCÍA, 2014).

En este contexto de penuria historiográfica podemos destacar aquellos proyectos cuyo objeto de estudio presenta una relación más estrecha con el nuestro, de manera que son referencias preferentes a la hora de establecer comparaciones y analogías, como el que viene estudiando el poblamiento rural andalusí en las sierras de Gúdar-Javalambre (Teruel), en donde se ha detectado un gran número de alquerías emplazadas en entornos que carecen de condiciones aptas para el desarrollo de regadíos y cuya vocación agrícola se orientó claramente hacia la explotación de los cereales de secano (ORTEGA, VILLARGORDO, 2020:
180). Este proyecto incluye, como el nuestro, la excavación arqueológica de una alquería, la de El Quemao, coetánea de La Graja (s. XI) y similar a las que venimos estudiando en el Corredor de Almansa en muchos aspectos: emplazamiento, tamaño, arquitectura o recursos, aunque también existen diferencias significativas que comienzan a desvelar lo heterogéneo y complejo que era el poblamiento rural andalusí incluso cuando no existen distancias cronológicas ni medioambientales $\mathrm{y}$, consiguientemente, los retos que aún ha de afrontar la investigación histórica al respecto. También existen importantes analogías en cuanto a geografía histórica y cronología con la investigación sobre las alquerías del valle del Salado en Guadalajara, un proyecto para el que se han empleado las herramientas de análisis del territorio propias de la arqueología espacial, aunque no se han efectuado excavaciones (GARCÍA-CONTRERAS, 2017).

En resumen, los objetivos científicos generales que nos hemos planteado al afrontar la investigación de estas alquerías, y en concreto con la excavación arqueológica en La Graja, son los siguientes ${ }^{8}$.

1. Aspectos asociados a la historia de este poblamiento rural. Determinar el origen de los núcleos rurales y los procesos históricos que dieron lugar a su formación. Su relación con el medio físico en el que se insertan, el aprovechamiento del mismo, los espacios productivos y, en general, el modelo socioeconómico. Intentar conocer, en la medida de lo posible, la evolución y transformaciones que experimentaron estos grupos campesinos, así como los posibles cambios en su relación con otros ámbitos sociales. Aproximarnos, finalmente, a las causas de la decadencia y conclusión de este patrón de poblamiento.

2. Aspectos relacionados con las características intrínsecas de estos asentamientos. Las diferencias entre ellos en cuanto a tamaño y ubicación topográfica. La distribución de sus espacios de habitación, asociados a unos determinados sistemas de producción agropecuaria sobre los que aún

8. Véanse en este sentido las interesantes reflexiones de García-Contreras (2017: 120-122) sobre las principales líneas de trabajo en relación al estudio de los núcleos rurales medievales. 
sabemos muy poco. A partir de la arqueología y los datos que se puedan extraer de las fuentes escritas, tratar de obtener información sobre la organización interna de estas comunidades campesinas: su estratificación, producción doméstica, composición familiar, redes comerciales, consumo, alimentación y especialización en el trabajo.

\section{EL POBLAMIENTO ANDALUSÍ EN LAMANCHA SUDORIENTAL}

Hasta comienzos del presente siglo no se contaba con información acerca del poblamiento andalusí del iqlìm de Chinchilla ni, en general, de la provincia de Albacete (NAVARRO ROMERO, 1998). Los únicos datos conocidos procedían casi exclusivamente de las fuentes escritas o de la toponimia, y daban como resultado un panorama en el que los asentamientos se concentraban en torno a las vegas de los ríos Júcar, Mundo y Segura, quedando entre medias amplios espacios vacíos en los que solo figuraban algunas localidades jalonando ciertos caminos. Este panorama ha cambiado sustancialmente a partir del desarrollo de las prospecciones en todo el territorio provincial, y de manera sistemática en la comarca sudoriental, compuesta actualmente por varios términos municipales, que han permitido rellenar precisamente uno de esos espacios en blanco alejados de las vegas fluviales ${ }^{9}$.

Los trabajos de investigación acerca del periodo islámico en el Corredor de Almansa y más concretamente sobre el yacimiento de La Graja, fueron emprendidos en el año $2000^{10}$, publicándose una década después el primer estudio al respecto (SIMÓN, 2010), al que siguió un artículo en la revista Al-Basit (SIMÓN, 2014a). En las Actas de la I reunión científica de arqueología de Albacete se presentó la comunicación "El poblamiento islámico en Albacete: alquerías y castillos" (SIMÓN, 2017); y ese mismo año un artículo en la revista Al-Qantara titulado "El poblamiento andalusí en las tierras de secano: el área sudoriental de La Mancha (ss. XI-XIII)", en este caso a cargo de P. Jiménez y J. L. Simón (2017). Más recientemente, se ha publicado una comunicación presentada al congreso internacional Defensive Architecture of the Mediterranean sobre "El hișn de Almansa (Albacete): fortificaciones y poblamiento" (JIMÉNEZ, SIMÓN, 2020).

En 2020, hemos llevado a cabo la primera campaña de excavaciones arqueológicas en la alquería de La Graja (Higueruela, Albacete), lo que nos ha permitido obtener datos relevantes que complementan y precisan significativamente la información aportada por las prospecciones previas. El primer resultado de dichos trabajos ha sido una comunicación presentada al XIII Congreso AIECM3, acerca de "La cerámica de la alquería de La Graja en su contexto: aportación a la historia del poblamiento andalusí en La Mancha sudoriental". De forma paralela, en el presente estudio daremos cuenta de los resultados de esa excavación, concretamente de lo relativo a la arquitectura, estratigrafía y materiales, así como una primera aproximación a las implicaciones históricas que se derivan del análisis del registro arqueológico.

El área objeto de estudio es el territorio castral o iqlìm de la medina de Chinchilla en época andalusí, un espacio cuyos límites exactos no conocemos con precisión pero que corresponde, aproximadamente, al tercio oriental de la actual provincia de Albacete (Fig. 1). Es un ámbito delimitado en su flanco este por las últimas estribaciones surorientales del Sistema Ibérico y las nororientales del Prebético, entre las que se abre paso el Corredor de Almansa, camino tradicional por donde transcurrió la vía Heraclea o Augusta, siendo un espacio de tránsito entre el Levante y el sureste peninsular con la Meseta y la Alta Andalucía. Por el norte, queda delimitado por el cañón del Júcar y el valle de Cabriel, entre Alarcón e Iniesta

9. Además de la prospección del área de Chinchilla, hemos podido llevar a cabo estudios espaciales en otras comarcas de la provincia de Albacete (SIMÓN, 2013, 2014a, 2014b, 2017; SIMÓN, HERNÁNDEZ, 2013; JIMÉNEZ, SIMÓN, 2020).

10. Los trabajos de prospección fueron financiados casi en su totalidad a través de varias anualidades por el Instituto de Estudios Albacetenses "Don Juan Manuel”, al igual que las topografías de varias de las alquerías documentadas. 
(Cuenca) y la Muela de Cofrentes (Valencia); por el sur linda con el Campo de Hellín, donde se unen los ríos Mundo y Segura; y, por el este, con los llanos que llevan al Campo de Montiel a través de las Lagunas de Ruidera. El territorio tiene una altitud media por encima de los $750 \mathrm{~m}$, con zonas que superan los $1.000 \mathrm{~m}$, por lo que presenta un clima mediterráneo con cierto matiz continental, que da lugar a una cubierta vegetal natural en la que predominan el encinar y el monte bajo. La ausencia de cursos fluviales y el relieve endorreico hacen que buena parte de las aguas pluviales vaya a parar a una serie de lagunas, unas salobres y otras de agua dulce en función del sustrato geológico, que han condicionado el poblamiento de la zona en todos los periodos históricos, pues se han escogido sus aledaños, así como los de los escasos manantiales y fuentes, para establecer los asentamientos. No es de extrañar que en este medio natural la producción agropecuaria de la zona haya estado conformada secularmente por los cultivos de secano - cereales, leguminosas, olivo, almendro y vid-y la ganadería extensiva -ovejas, cabras, así como ganado vacuno y equino-, estos dos últimos asociados a las tareas de tiro y labranza.

El trazado de las vías de comunicación fue uno de los factores determinantes del modelo de ocupación del territorio a lo largo de la historia, tanto desde el punto de vista del posicionamiento de los núcleos de población, como de las infraestructuras que son necesarias para su protección -castillos y torres-, uso comercial - posadas, corrales y aljibes-, tránsito de personas -ya sean civiles o tropas militares-, etc. El uso de dichas vías, y consiguientemente su importancia, quedará a su vez determinado por la situación política y administrativa de la región, con periodos de aislamiento, como son la fase emiral y califal, frente a otros de un claro valor estratégico, en ocasiones singular, como parece que fue durante época taifa y almohade. La posición geográfica del territorio que nos ocupa en el solar peninsular le confiere un importante valor estratégico al encontrarse atravesado por rutas naturales de comunicación - tanto en dirección norte-sur como este-oeste, que unen la Meseta Sur con el Levante y el Sistema Ibérico con la Alta Andalucía y Murcia-, que condicionaron los dos ejes principales de comunicación en época romana: la vía que unía Cástulo (Linares) y Sagunto, y la que conectaba las ciudades de Complutum (Alcalá de Henares) y Carthago Nova (Cartagena). La primera era la Vía Augusta o Vía Hercúlea, que descendía de Játiva por el Valle de Montesa y seguramente por el alto Vinalopó, el paraje de los Alhorines, hoy en el término de Villena (Alicante), en donde se bifurcaba en dos ramales: uno que seguía por el Vinalopó hasta la costa del Mediterráneo y otro, llamado también el "Camino de Aníbal", que se dirigía hacia la Bética por Castulo y en cuyo itinerario se encontraban mansiones como Saltigi (Chinchilla), Libisosa (Lezuza) y Mentesa (RUBIERA, 1987: 357). Otra importante vía romana es la que aparece en los itinerarios como Laminio-Caesar Augusta (Lagunas de Ruidera-Zaragoza), que después de pasar por Caput Aquae Fluminis Anae (Ossa de Montiel) se unía al Camino de Aníbal para dirigirse a Chinchilla y de allí torcer hacia el Júcar, río que atravesaba por el vado Valdeganga, quizás a la altura del paraje de Puente Torres.

Uno de los principales papeles de las vías de comunicación naturales de estas tierras fue su uso para la trashumancia comarcal y regional, base esencial de la economía de la zona tal y como lo señalan los textos bajomedievales pero también, excepcionalmente, las fuentes árabes. Estas últimas demuestran que la ganadería fue una actividad clave en la producción y elaboración de la lana en las tierras albaceteñas, reflejada hasta en la toponimia —en la provincia de Albacete podemos citar la rutba o aduana relacionada con la lana de la cual surge La Roda o Balazote (Balāt ass-Sūf) que significa calzada de la lana-, así como la repetida mención a la elaboración de tapices de lana (wata' as-sūf) en Chinchilla (JIMÉNEZ, SIMÓN, 2017: 245-248). Esta actividad se verá revitalizada tras la conquista y el alejamiento de la frontera, aprovechando rutas preexistentes islámicas para configurar un sistema de cañadas, veredas, cordadas y coladas, que permitían el 
tránsito de ganados de forma franca desde los pastos de verano a los de invierno.

De las cañadas que cruzaban la comarca, una de las principales era la Vereda Real de Los Serranos, que con dirección norte-sur unía el Sistema Ibérico con el Campo de Cartagena, pasando por Higueruela, la parte oriental del actual término de Chinchilla, Bonete, Corral Rubio y Montealegre del Castillo, es decir, a través del territorio que venimos estudiando unía el Valle del Júcar con el Altiplano murciano. En sentido oeste-este corría la Vereda Real de Andalucía a Valencia que, atravesando la parte meridional del término de Chinchilla, llegaba a Bonete, pasaba a Almansa donde se bifurcaba hacia Valencia, bien por Enguera o por el Puerto de Almansa hacia Fuente la Higuera, o bien hacia Alicante por Caudete y Villena en dirección hacia Salinas y Pinoso.

Los yacimientos catalogados hasta la fecha los podemos agrupar en husūun (asentamientos de tamaño mediano, normalmente protegidos por una fortaleza sobre una elevación); alquerías, en altura o en llano (qurā); y cuevas refugio. La única ciudad (madina) era precisamente Chinchilla (madīnat Šantiŷŷāla o Ŷinŷāla), la cabeza administrativa de este extenso territorio (CHAVARRÍA, 2011: 145-168; JIMÉNEZ, SIMÓN, 2017: 223 y 224), que se hallaba en el límite noroccidental de la cora de Tudmīr según al-'Udrī (1965: 42 y 63). Se ubica sobre un espolón rocoso en el extremo suroccidental del conjunto montañoso de Montearagón, en el centro de la actual provincia de Albacete, entre el valle del Júcar y las tierras del Corredor de Almansa que permiten el paso desde el Vinalopó y La Costera o las tierras altas de Murcia hacia el centro de la Meseta (PONCE, 1989). Según al-Idrīsī (1968: 175, 195 (texto árabe) y 210, 237 (traducción francesa)), Chinchilla era una ciudad mediana, defendida por una fuerte y extensa fortaleza, que estaba rodeada por jardines o almunias y arboledas. Allí nacieron varios personajes entre la segunda mitad del siglo X y la primera del siglo XI que alcanzarán la suficiente relevancia como para figurar en repertorios de la época como los de Ibn Baškuwāl e Ibn al-Faradī (CHAVARRÍA, 2011: 156). De su trama urbana medieval solo podemos identificar en la actualidad la presencia de la alcazaba, en la parte más elevada del cerro; un albacar o espacio abierto en el lado que da al caserío y la medina que se extendía hacia la parte baja del cerro, rodeada de una muralla que partía de la alcazaba (SIMÓN, 2011). En su interior, los únicos restos de época andalusí que se conocen, hasta la fecha, corresponden a las salas caliente y templada de un baño público (GARCÍA-SAÚCO, SANTAMARÍA, 1986).

De la madina de Chinchilla dependían varios husūun situados en los límites del iqlìm, como los de Alpera, Higueruela, Almansa y Carcelén, o las fortalezas del Júcar que se constituyeron en un at-Taǵr o frontera en el avance del reino castellano entre finales del siglo XII e inicios del siglo XIII, que ya analizamos en un estudio general sobre las fortalezas de Albacete (SIMÓN, 2011). Su eclosión en el siglo XI debió de estar relacionada con el incremento demográfico de la zona debido a una colonización del campo que se extendía entre esos puntos fortificados (JIMÉNEZ, SIMÓN, 2017), así como a las necesidades defensivas asociadas a la inestabilidad política del último tercio de siglo, según trataremos de analizar en este trabajo. Estos poblados fortificados de altura continuarán desarrollándose durante los siglos XII y XIII hasta la conquista castellana; después de la cual no todos pervivieron y algunos de ellos, como Higueruela y Carcelén, quedaron despoblados hasta bien entrado el siglo XIV.

En este territorio abundan las cuevas refugio, que estarían ligadas a las actividades ganaderas y silvícolas ${ }^{11}$. Su uso pudo ser estacional y en algunas ocasiones permanente, tal y como lo muestran las construcciones que se levantaron al exterior, ampliando y mejorando las condiciones de vida de sus moradores y relegando el abrigo a una utilización exclusivamente ganadera, como corral. Ejemplo de ello

11. Al igual que sucede con las cuevas ocupadas del valle del Salado "cuya ubicación revela un aprovechamiento agropecuario de los pasos entre los montes y de las zonas más altas de los páramos” (GARCÍA-CONTRERAS, 2017: 125). 
sería la Cueva Negra del Mugrón, entre Almansa y Ayora, al exterior de la cual se construyó una edificación con una crujía compartimentada en tres estancias, para el refugio y residencia de sus moradores, y un patio o corral anexo en el cual se levantaron pequeñas estancias para los aperos o para las necesidades específicas del ganado, como las parideras. Por su tamaño y ubicación parece lógico suponer que estarían relacionadas con las alquerías próximas del llano, si bien es posible que tuvieran una cierta autonomía funcional. Son especialmente abundantes en la cara meridional de las sierras de Chinchilla, Higueruela y Carcelén. En algunas ocasiones se documentan en la cara norte de los relieves, a cotas de altura considerable, circunstancia que debe ponerse en relación con el aprovechamiento de los pastos de verano (SIMÓN, HERNÁNDEZ, 2013) y los sistemas de transterminancia de corta distancia.

\subsection{Las alquerías en llano}

Dentro de las formas de poblamiento, el conjunto más numeroso y significativo de asentamientos andalusíes de la zona es el de las alquerías en llano, que se distribuyen especialmente en el espacio intermedio entre los husūn (Fig. 1). Solo están ausentes en el entorno más próximo de la madina de Chinchilla, que genera a su alrededor un hinterland deshabitado de unos 10-15 km de radio, es decir, unas dos o tres horas de camino. Aunque algunas de ellas contaron, seguramente en un momento tardío, con una torre defensiva (Burjaharón o Torre Grande en Almansa, la Torre de Pechín en Montealegre, el Torrejón de Carcelén, o la alquería de Bogarra en Caudete), la mayoría carecía de elementos defensivos. De hecho, el número de las que conocemos es cada vez mayor, pese al sesgo de la información proporcionada por las prospecciones debido a que estas se conservan peor que las emplazadas en altura por causa de las intensas tareas agrícolas de las últimas décadas ${ }^{12}$. De tamaño variable, algunas de ellas parecen haber contado con escasamente una decena de casas, como por ejemplo La Toyosa; mientras que otras debieron de alcanzar las 40 o 50, como sucedía en Los Villares del Bachiller (Chinchilla), aunque en la mayoría de los casos el número de viviendas oscilaría entre ambas cifras.

Si observamos su distribución en el mapa podemos apreciar que preferentemente aparecen agrupadas en torno a las cañadas 0 las vegas de la zona ${ }^{13}$, en conjuntos de 5 a 8 asentamientos que incluyen alquerías y cortijos compuestos por solo una o dos viviendas, que quizás pudieron compartir algún tipo de establecimiento comunitario, como un oratorio o un refugio en algún punto bien protegido para las ocasiones en que hubiera peligro. Así podrían interpretarse las agrupaciones de alquerías en torno a algunos hușūn, como los de Higueruela y Alpera. Muchas se sitúan en tierras que aún hoy en día, pese a la mecanización del campo, son espacios baldíos, bien por situarse sobre lomas donde el afloramiento del sustrato rocoso y la escasez de suelo las han hecho inservibles para el cultivo, bien por tratarse de zonas de monte bajo, tradicionalmente dedicado al pastoreo, pudiendo encontrarse en los límites de grandes propiedades que han usado sus restos como majanos donde acumular las piedras de los bancales de cultivo. Se emplazan en terrenos de laderas con suave pendiente, especialmente en lugares protegidos de los vientos dominantes del noroeste y norte, en donde tengan asegurado el abastecimiento de agua mediante pozos y manantiales. La mayoría de las alquerías evitan ocupar las tierras de labor más aprovechables y las zonas de charcas y lagunas. Son excepcionales las que están situadas junto a pequeñas vegas, como la de Tobillos en Alpera (SIMÓN, 2011: 167-266), que pudieron explotar espacios

\footnotetext{
12. La mecanización del campo en la segunda mitad del siglo XX y las necesidades para la explotación industrial y extensiva de determinados cultivos, han supuesto una modificación y transformación del territorio que ha alterado por completo el paisaje en determinados ámbitos, en especial en los llanos (SIMÓN, SIMÓN, 2018: 105)

13. El trazado de las cañadas tradicionales se remonta con seguridad a la Baja Edad Media o comienzos de la Edad Moderna, aunque todo parece indicar que tienen un origen muy anterior, que posiblemente fueron usadas desde la Antigüedad y con toda probabilidad en época islámica.
} 
agrícolas irrigados de escasa extensión y sin posibilidades de ampliación.

Desde el punto de vista urbanístico, los asentamientos muestran un estado temprano de la evolución del caserío, caracterizado por una cierta dispersión de los edificios, sobre todo en la periferia del núcleo central, y la existencia de espacios de paso amplios e irregulares que aún no presentan las alineaciones de fachada propias de una calle formada. Teniendo en cuenta los aspectos antropológicos, tanto las cuestiones hídricas en relación a afluentes, acuíferos, ramblas y pluviometría como la falta de una infraestructura relacionada (acequias, azudes, etc.), el emplazamiento de las alquerías junto a vías pecuarias tradicionales, las características de los patios corrales asociados a las viviendas y la presencia de lo que parecen rediles comunitarios en algunos de los asentamientos, creemos que, al igual que en épocas más recientes, las comunidades medievales de esta comarca debieron de basar su sustento en la agricultura de secano y en la ganadería, especialmente ovina y caprina. Entre las alquerías en llano más destacadas se encuentran La Toyosa y El Boquerón (Chinchilla); la Carrasquilla, el Vallejo de la Casa de la Vega y el Cerrico de los Conejos (Corral Rubio); la Casa del Sol I y II, la Casa de la Zorra y Malefatón (Alpera); Hoya Matea (Almansa); Dolonche (Carcelén); el Villar de Hoya Honda, los Pocicos y La Graja (Higueruela), esta última es la que ha sido objeto de la primera campaña de excavaciones arqueológicas en 2020.

\subsection{Los asentamientos en altura}

Una variante de estas alquerías son las que se sitúan en altura; se trata de asentamientos de pequeño tamaño pues no llegan a las 10 casas y una extensión que ronda los 1.000 a $2.000 \mathrm{~m}^{2}$. Están ubicados en las laderas de pequeños cerros que apenas cuentan con defensas naturales o artificiales aparte de la escasa pendiente de la elevación y, ocasionalmente, con una cumbre, habitualmente reducida y sin señales de ocupación, que pudo haber servido de refugio, aunque no existen evidencias que lo confirmen. Ni siquiera el dominio estratégico que podría derivarse de su ubicación en alto justifica su emplazamiento pues en algunos casos quedan sus campos visuales ocultos por elevaciones próximas, o abiertos a espacios sin mayor interés.

Un ejemplo claro de este tipo sería Los Castillicos ${ }^{14}$ de Higueruela (JIMÉNEZ, SIMÓN, 2017: 227-229), un asentamiento en ladera defendido por dos barranqueras que lo flanquean, con dos alineaciones de casas con corral, adosadas las unas a las otras y dispuestas de forma escalonada en la ladera oriental, protegidas de los vientos dominantes por el farallón rocoso de la cumbre. En este caso, el conjunto parece que quedaba delimitado por un muro que efectuaría las funciones de cerca, dispuesto sobre el afloramiento rocoso que remata la parte alta de las laderas.

En este último grupo habría que incluir igualmente un enclave de extensión sensiblemente mayor como el Castellar de Meca en su fase islámica, despoblado que alcanzaba la considerable extensión de 13 ha, en donde se incluyen tanto las viviendas como los corrales y las amplias zonas vacías entre las casas. Efectivamente, la densidad de población era muy baja, por lo que seguramente se puede considerar como una gran alquería, aunque ciertamente el hallazgo de algunos pequeños hornos para la fabricación de cerámica acredita la categoría de este asentamiento. Las viviendas del Castellar, en cualquier caso, son similares a las del resto de las alquerías que venimos comentando: las de menor tamaño compuestas por una sola nave o crujía rectangular con el vano abierto hacia el sur o sureste, aparentemente sin compartimentaciones interiores; y otras de mayor tamaño configuradas por una planta rectangular que comprende una crujía de dos o tres estancias con vanos abiertos a un gran corral o patio.

Al estudiar la comarca de Gúdar-Javalambre también se identificó -junto a los

14. El yacimiento es conocido en la zona como La Rambla o Mingo García, en el macizo de Molatón. 
establecimientos con caseríos abiertos sin especial interés por la defensa que podríamos identificar con nuestras alquerías en llano-, otro grupo, "cuya localización solo puede explicarse por una decidida voluntad de maximizar la defensa de sus habitantes, encaramados sobre elevaciones alejadas de los campos de cultivo, en especial reversos de cuestas poco prominentes" (ORTEGA, VILLARGORDO, 2020: 181); características similares a las de las alquerías en altura que hemos descrito en el Corredor de Almansa.

Finalmente, en la comarca de la montaña turolense también se ha documentado una serie de instalaciones en altura, a veces pequeñas mesas rocosas que, a las ventajas defensivas de su enriscada topografía, añaden algunas obras bastante sumarias como algún paño amurallado, un tipo de asentamiento del que contamos también al menos con un ejemplo en el territorio que nosotros estudiamos: Mompichel o Cerro de las Tinajas. Se trata de un cerro aislado y amesetado en el que se ha sucedido la ocupación desde el Calcolítico y en época andalusí desde los siglos X-XI hasta la conquista castellana; en su cumbre solo se constata la presencia de dos aljibes excavados en la roca, uno de ellos con restos de la bóveda de ladrillo que lo cubría, y un muro perimetral escasamente conservado. La meseta de la cima es exigua, apenas alcanza los 1.500 $\mathrm{m}^{2}$ de superficie, y al pie de la elevación no se han detectado restos de ocupación, por lo que creemos que solo se puede interpretar como un refugio temporal habilitado por los campesinos de las alquerías del entorno.

\section{LA ALQUERÍA DE LA GRAJA: ASPECTOS GENERALES}

El yacimiento de La Graja se podría identificar como una de las alquerías en llano a que antes hacíamos referencia. Se sitúa al norte del término de Higueruela (Albacete) en el valle de la Cañada de Pajares - cabecera de la vega de Alpera que se desarrolla más abajo-, discurre en sentido oeste-este, tiene una altitud media de $1.000 \mathrm{~m}$ sobre el nivel del mar y está delimitado al sur por la sierra del Molatón (1.245 m) y al norte por la Cuerda de la Doblona (1.056 m) y el Malefatón $(1.105 \mathrm{~m})$. Encauza las aguas de los macizos serranos del sector septentrional de la sierra de Chinchilla-Higueruela y permite el paso de cañadas, cordeles y veredas de ganado, como la Cañada Real de Los Serranos, que van del Valle del Júcar al Corredor de Almansa y al Altiplano de Yecla y Jumilla, uniendo las serranías conquenses con el litoral murciano. El yacimiento quedaría, según la cartografía de 1887 de IGN, entre el Camino de Higueruela a Alatoz y el de Higueruela a las Casas de Valiente (Villavaliente), ambos grafiados como caminos carreteros.

El clima del área en la que se encuentra La Graja es acusadamente continental, con un índice de pluviometría de unos 400-500 ml anuales, superior al del resto del entorno. La zona dispone de un buen número de fuentes y manantiales alimentados por los aportes pluviométricos y nivales, especialmente frecuentes y cuantiosos en invierno. Entre la vegetación tradicional de encinas, coscoja, sabinar y matorral, se han ido abriendo espacios de cultivo de cereales que, en las últimas décadas, se ven sustituidos por viñedos. Pero el recurso económico más importante de estas tierras ha sido la ganadería, especialmente las ovejas de la variedad manchega, que han sabido adaptarse al terreno para proporcionar carne, leche y lana, fuente de riqueza secular y un seguro contra las malas cosechas, como muestra el elevado número de corrales en las vertientes meridionales. De manera muy resumida, estas son las características físicas del territorio en la actualidad y de la economía tradicional, ahora bien, ¿en qué medida son extrapolables a época andalusí? En ausencia por el momento de estudios paleoclimáticos del área en cuestión basados, por ejemplo, en análisis palinológicos, son muy pocos los testimonios con que contamos para conocer cómo era el medio natural de la Cañada de Pajares de Higueruela en el pasado. El más antiguo es un relato general del campo chinchillano recogido en las Relaciones de Felipe II, del tercer cuarto del siglo XVI, en el que se describe un paisaje natural que sustancialmente habría cambiado poco desde época islámica. Según esta descripción, el término de Chinchilla: 
"es tierra montuosa por la parte del oriente [en donde se encuentra la alquería de La Graja] y mediodia, que por la parte del poniente y setentrion es tierra muy llana; no ay otra cosa sino atochares y espartales con algunos pocos de rromeros y aliagas y coscoxas pocas. Como es tierra antigua tiene ya muy lexos la leña; abunda de pinos y enzinas, rromerales y rretamales en gran cantidad; ay mucha coscoxa, en la qual se suele criar mucha grana algunos años" (CARRILERO et al., 2014: 83).

Entre los pocos recursos que proporciona la zona boscosa se señala la caza (CARRILERO et al., 2014: 84). En términos muy parecidos es descrita el área montuosa de Higueruela, y en concreto de la Cañada de Pajares, a mediados del siglo XIX en el Diccionario de Madoz; un espacio donde se da "atocha, abundantes leñas de romero y enebro, con algunas matas de pinar que apenas puede aprovecharse algún palo para construcción, y en el puente llamado Cañada Pajares, se ve algún carrascal, restos del mucho y frondoso que antes había" (MADOZ, 1847, t. II: 82). Desde el punto de vista de las posibilidades agrícolas las Relaciones de Felipe Il indican que el término era "tierra donde se suele coger pan", en particular, de Higueruela se destaca que "abia veynte y çinco labradores, no rricos, por estar en la sierra". El texto enfatiza que la riqueza del término es la agricultura de secano y la ganadería de oveja, cabra y animales de labranza y tiro, burros, mulas y, en mucha menor medida, bóvidos. Se hace escasa referencia a otros dos de los productos básicos de la triada mediterránea: el viñedo se da en algunas de las aldeas del alfoz de Chinchilla situadas a cotas más bajas; no hay noticia alguna del cultivo de olivo o de la presencia de almazaras pues, de hecho, se dice explícitamente que el aceite se trae de los pueblos del sur de la provincia o de Andalucía.

En las Relaciones se describen los altos y sierras del término de Chinchilla que se extienden por el sury por oriente, un área que incluye el territorio de Higueruela y, en concreto, el que circunda La Graja por todos lados excepto por el meridional, donde se extiende la cabecera de la vega de Alpera, al sur de la cual de nuevo se expande el monte. Parece lógico pensar que este escenario, que apenas había variado entre los siglos XVI y XIX, podría ser similar en el siglo $X I$, dado que no se produjo entre tanto un cambio climático que justificara una transformación del paisaje natural; no obstante, existen indicios que demuestran que ni siquiera este era estático. Así, el Diccionario afirma que en el siglo XIX el monte bajo había sustituido en gran medida al bosque de carrascas "mucho y frondoso que antes había"; la madera de este tipo de encina, que en estado salvaje crece en forma de chaparros, no es muy apropiada para usarla en labores de carpintería porque es muy dura e imputrescible aunque también difícil de trabajar, pero sí es muy apropiada como leña y para hacer carbón vegetal, actividad muy extendida en esta zona puesto que los relatores destacan que en el siglo XVI los habitantes de Chinchilla que no son agricultores o ganaderos son soldados, cazadores o carboneros.

Dado que leña y carbón de encina constituían hasta el primer tercio del siglo XX los principales combustibles domésticos en buena parte de la península ibérica, se puede inferir que la tendencia a la deforestación ha sido seculary que en el periodo taifa el medio natural presentaba unas características parecidas a las que describen los textos posteriores, aunque la presencia del bosque mediterráneo perennifolio sería aún más dominante, en detrimento de un monte bajo que es el resultado de procesos antrópicos de sobreexplotación prolongados en el tiempo. De ello se deduce que los recursos silvícolas y cinegéticos podrían ser sensiblemente más ricos en el siglo XI de lo que fueron quinientos años después, en 1576, cuando los describen los relatores. Se puede afirmar igualmente que esas características físicas del territorio que perduraron a lo largo de siglos también condicionaron fuertemente la actividad agropecuaria, a pesar de que tanto la agricultura como la ganadería tienen mucho que ver con circunstancias históricas y con aspectos sociales y culturales. Las limitaciones que impone el medio natural a la agricultura de la zona se han puesto de manifiesto a lo largo de amplios periodos de tiempo, de manera 
que la elaboración de la Carta Arqueológica de Higueruela y los términos colindantes ${ }^{15}$, mostró la casi inexistencia de asentamientos de época ibérica y romana.

Finalmente, debemos destacar que los análisis antracológicos practicados a las muestras tomadas durante esta primera campaña de excavaciones en la casa 16 de La Graja ${ }^{16}$, arrojan, como resultados preliminares, la presencia mayoritaria en todas las unidades estratigráficas de madera de pino y de leguminosa, incluso en el hogar, a las que acompañan taxones de Juniperus sp. (enebro/sabina), Monocotiledoneae (plantas monocotiledóneas), Quercus ilex/ coccifera (encina/coscoja) y Rosaceae (madera de rosácea); todo lo cual demuestra que en términos generales el ambiente climático del s. XI no difería esencialmente del que describen las Relaciones.

Al igual que sucedía en toda la extensión del término de Chinchilla en tiempos de Felipe II, la agricultura practicada por la comunidad de La Graja en el siglo XI estaría limitada a los cultivos de secano practicados en el fondo de la vega que se extiende a los pies de la alquería y sería casi exclusivamente cerealista, quizás complementada con leguminosas, cuyo cultivo se realizaba en campos abiertos entre el bosque de encinas, coscojas y pinares, del que aún hoy quedan abundantes islas entre las áreas cultivadas. Este espacio de cultivo se debió de ir ampliando con el paso del tiempo, como lo demuestra la cartografía histórica. El cultivo de cereales, a pesar de todas las limitaciones expuestas, debió de ser una actividad fundamental para estas comunidades pues el consumo de estos productos era parte fundamental de la dieta de las sociedades preindustriales, y su facilidad para almacenarlos y conservarlos hacía de ellos un seguro para la subsistencia campesina; prueba de ello es la existencia, por el momento, de un silo de dimensiones considerables conservado en el área sudoccidental del yacimiento, un sector afectado por las nuevas roturaciones de la segunda mitad del s. XX que han borrado los restos arquitectónicos, así como las noticias transmitidas por agricultores de la zona sobre la existencia de otros depósitos subterráneos de este tipo que servían para guardar grano. A ellos hay que sumar el silo que fue descubierto en el patio de la casa 16 durante la segunda campaña de excavaciones (2021).

No obstante, creemos que una de las particularidades que distinguían a estos asentamientos de otros andalusíes de la misma época es la importancia que debió de tener la ganadería en el conjunto de su economía a juzgar por una serie de indicios que así parece acreditarlo, como la ubicación de los asentamientos a lo largo de las cañadas y vías ganaderas o la existencia en las alquerías de amplios corrales, tanto comunitarios como privados. Incluso, la propia planta de las casas, que guarda muchas similitudes con la de los cortijos tradicionales de la zona, presenta evidencias que demuestran la actividad esencialmente ganadera de sus moradores, principalmente el patio-corral, un espacio sensiblemente diferente de los patios centrales de las viviendas andalusíes propias de los núcleos urbanos o de las alquerías agrícolas, como veremos más adelante.

El yacimiento de La Graja fue descrito por primera vez a finales del siglo XIX por el arqueólogo francés Pierre Waltz en un artículo publicado en el Bulletin Hispanique de la Universidad de Burdeos (WALTZ, 1900), después de una visita al yacimiento que tuvo lugar en septiembre de 1899. El buen estado de conservación del yacimiento le permitió apreciar varias líneas de estancias y una zona de tránsito entre ellas que denominó "avenida". Incluso aportó las plantas de tres viviendas realizadas a partir de los restos visibles en superficie, aunque se trata de interpretaciones confusas y poco acertadas. Le desconcertó la ausencia de cerámica, de hecho, es muy escasa en superficie, lo que le impidió encuadrar cronológica y culturalmente el yacimiento, que supuso protohistórico o incluso anterior.

15. De cuyo equipo de redacción formamos parte (José Luis Simón García).

16. Llevados a cabo por Mónica Ruiz Alonso, del Departamento de Botánica de la Universidad de Granada. 
El núcleo principal del sitio parece que se conserva tal y como Waltz lo pudo ver en 1889, con ligeras afecciones en zonas puntuales. Tiene una superficie de 6,8 ha aproximadamente, extendiéndose $512 \mathrm{~m}$ en el eje esteoeste que coincide con las curvas de nivel, y 273 $m$ de norte a sur, es decir, en perpendicular al desnivel del cerro. Se han individualizado hasta la fecha 46 estructuras construidas en el yacimiento, de las que una treintena, aproximadamente, corresponde a viviendas compuestas, básicamente, por crujías oblongas dispuestas en torno a un corral-patio. Se distinguen también 8 edificios de reducido tamaño y planta simple de forma rectangular, que se emplazan en zonas periféricas o de forma aislada en espacios centrales, sin otro tipo de construcciones asociadas; cabe la posibilidad de que se trate de viviendas en su estadio más simple, carentes de patio, corral y de otras crujías; o que algunas de ellas estuvieran destinadas a otros usos aún por determinar. La mayoría de las viviendas está orientada a mediodía, con un cierto giro hacia el sureste, lo que hay que poner en relación con la búsqueda de protección frente a los vientos del noroeste dominantes en la zona.

Desde el punto de vista urbanístico, el plano del asentamiento en el momento de su abandono, hacia el último tercio del siglo $\mathrm{XI}$, demuestra la inexistencia de planificación previa en la distribución de unos edificios que solo parece condicionada por la orientación preferente de las viviendas, la pendiente de la ladera y el respeto a las servidumbres de paso (Fig. 2). Asimismo, denota un estado temprano
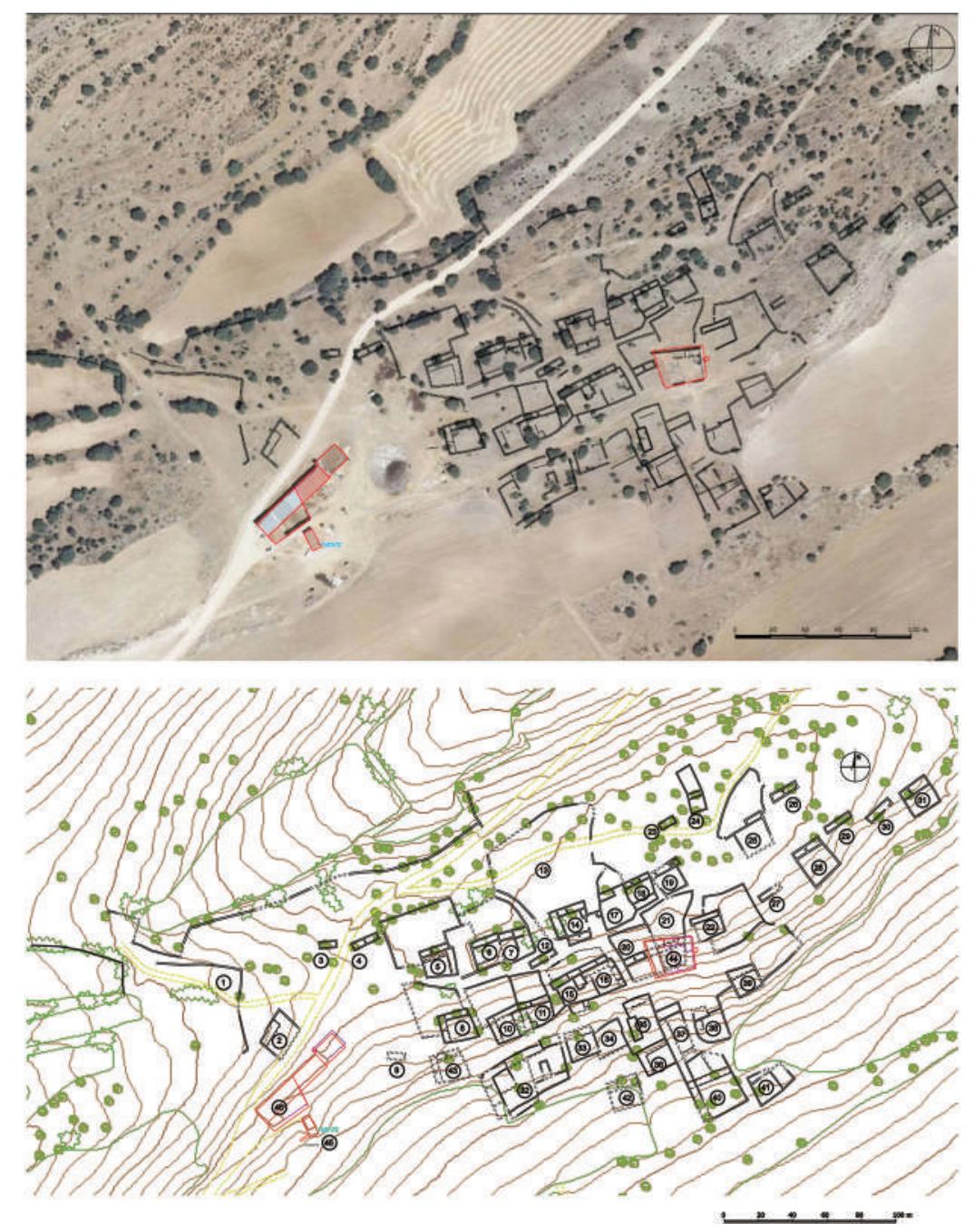

Fig. 2. Ortofotografía y plano de la alquería de La Graja. 
de la evolución del caserío, caracterizado por la dispersión de los edificios, sobre todo en la periferia del núcleo central, así como por la existencia de unas pocas calles junto con espacios de circulación amplios e irregulares que aún no presentan las alineaciones de fachada propias de una vía pública formada. Los grupos de casas, normalmente no más de 2, configuran proto-manzanas rectangulares que conforman bandas edificadas entre las que se sitúan las calles principales en paralelo a las curvas de nivel, y las calles secundarias en perpendicular a la pendiente. Al norte y oeste del yacimiento se aprecian largos tramos de muro de ancho similar a los de las fachadas exteriores de las viviendas, que parecen estar individualizando grandes espacios cercados que creemos podrían ser rediles; no se trata de murallas, de hecho, el asentamiento carece de defensas colectivas y ni siquiera las viviendas están dispuestas a casa-muro. Esta ausencia de murallas, torres o fortalezas es una característica general de las alquerías de la comarca que hemos localizado durante las prospecciones.

En el centro de la alquería existe un espacio vacío a modo de plaza en el que convergen varias calles, en medio del cual se alza un edificio rectangular que ha podido ser identificado como una mezquita en el transcurso de la segunda campaña de excavaciones en La Graja, llevada a cabo en 2021. Es un oratorio canónico dentro de los tipos de mezquitas rurales andalusíes que conocemos: está compuesto por una sala de oración de planta rectangular, de $10 \times 3 \mathrm{~m}$, cuyo muro de la quibla se orienta canónicamente al sureste, la dirección de La Meca hacia la que se deben postrar los creyentes durante la oración. Cuenta con un mihrab (mihrāb) que en este caso es un nicho rectangular que tiene unas dimensiones interiores de aproximadamente $80 \mathrm{~cm}$ de fondo por $95 \mathrm{~cm}$ de ancho. En este mismo muro, justo al oeste del mihrab, se abre la puerta de entrada desde el exterior. El edificio está fabricado en su totalidad con mampostería trabada con mortero de tierra, a la que se pretendió dar relevancia mediante el empleo de grandes bloques verticales de piedra u ortostatos que se sitúan en las esquinas, en las jambas y también en medio de los muros, entre paños de mampostería, conformando así un aparejo que recuerda al opus africanum clásico.

\section{LA CASA 16}

Los trabajos arqueológicos desarrollados en esta primera campaña permitieron delimitar y excavar una parte sustancial de la casa $16^{17}$, aunque no se ha exhumado totalmente. Se planteó una zona de intervención de $22 \mathrm{~m}$ (N-S) x 20 m (E-O) (Fig. 3) en donde se comenzó retirando la vegetación superficial y las piedras sueltas de mediano y pequeño tamaño, lo que nos permitió definir con más precisión las estructuras que ya se identificaban en superficie.

Estaba delimitada al sur y al norte por las dos calles principales que en dirección esteoeste articulaban el caserío de la alquería; al este, la vivienda daba a una calle de dirección norte-sur que unía las dos vías anteriores; por el oeste, lindaba con la casa 15. Los frentes norte y este de la casa, que estaban ocupados por sendas crujías, pudieron ser delimitados perfectamente y excavados casi en su totalidad; también ha podido identificarse el trazado del muro que cerraba el patio por el sur, aunque no ha sido delimitado en toda su extensión dado que el patio solo ha sido excavado parcialmente y de manera superficial; finalmente, el muro que cerraría el patio por el oeste, separando esta vivienda de la número 15, no ha podido ser definido. La limpieza se extendió a los derrumbes de la casa en las calles situadas al este y norte de la misma, con el fin de delimitarla mejor.

Hasta donde conocemos, la vivienda tenía, al menos, una extensión de unos $21 \mathrm{~m}$ (N-S) x 19 m (E-O), formando un total de $399 \mathrm{~m}^{2}$

17. La numeración de las construcciones es la atribuida en el estudio que se efectuó sobre estas alquerías anteriormente (SIMÓN, 2014a). 


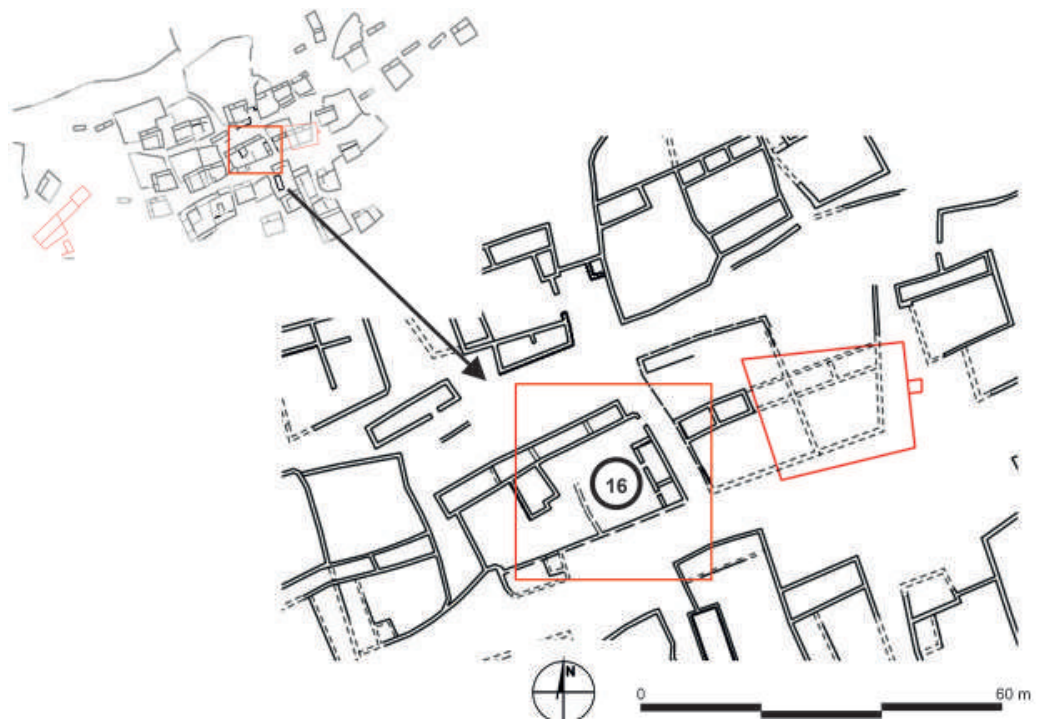

Fig. 3. Plano de la alquería de La Graja con indicación del emplazamiento de la casa 16.

aproximadamente, a falta de confirmar que efectivamente no se extendía al sur del muro que cerraba el patio por este lado, ni al oeste del que suponemos que la separaba de la casa 15.

\subsection{Estratigrafía}

La excavación arqueológica de las 4 estancias que se abren al patio de la casa 16 ha revelado una composición estratigráfica análoga, relativamente sencilla, que describiremos a continuación.

1) El nivel más superficial está compuesto por tierra suelta con abundantes raíces de la hierba que crece de manera generalizada y material orgánico procedente de los excrementos del ganado que pace por la zona. Cuenta también con una proporción considerable de piedras de diferentes tamaños procedentes de la ruina del edificio. Este nivel ofreció material cerámico escaso, rodado y fragmentado, evidenciando su exposición prolongada a la intemperie.

2) El siguiente estrato es un potente nivel de escombros compuesto principalmente por piedras análogas a las del superficial, en este caso revueltas con una tierra blanquecina originada a partir del barro con que se tomaba la mampostería y los alzados superiores de los muros, en los que creemos que la tierra era más abundante que en los zócalos (Fig. 8). Este estrato no suele presentar un espesor homogéneo, sino que parece haber sido mayor junto a las paredes, decreciendo hacia el centro de las dependencias. Aporta escasa cerámica y esta, por lo general, consiste en fragmentos pequeños, desgastados e inconexos, recubiertos de la misma capa blanquecina que conforma la tierra del nivel, por lo que creemos que estamos mayoritariamente ante materiales que estaban incluidos en la fábrica de los muros, seguramente como relleno de las tapias de tierra que conformaban la parte superior de los alzados.

3) Bajo este estrato suele aparecer una capa más fina de tierra, más suelta, con pocas piedras y estas por lo general pequeñas, que se asienta directamente sobre los suelos y que debe de haberse formado durante los años en que las viviendas permanecieron abandonadas pero sus muros aún no habían colapsado. En el caso de la estancia nororiental, que hemos identificado claramente con la cocina, este nivel está mezclado con cenizas y carbones abundantes. Es aquí donde han aparecido los escasos restos de recipientes cerámicos más o menos completos que deben atribuirse al momento de abandono de la vivienda y que reposaban sobre los pavimentos. 
4) Finalmente encontramos los suelos: en las habitaciones del frente oriental están conformados en parte por la roca tallada y alisada junto con zonas en donde se aplicó tierra apisonada con el fin de conseguir un horizonte homogéneo, mientras que en la estancia de la cocina está compuesto básicamente por una capa poco consistente de tierra y cal. Solo conocemos una parte mínima del suelo del patio, por lo que la información al respecto es incompleta; lo que hasta ahora se ha podido apreciar es de nuevo la roca base alisada combinada con tierra apisonada.

Los restos materiales encontrados (cerámica, metales y huesos) han sido muy escasos en general y en todos los niveles; no obstante, eran relativamente más abundantes en el estrato situado directamente sobre los suelos. Estos factores nos hablan del proceso de abandono paulatino, donde las estancias quedarían abiertas hasta su colapso y dejando únicamente el material de desecho, como apunta la cerámica fragmentada y dispersa o los metales ya inútiles (herradura y hoja de cuchillo muy deteriorados).

\subsection{El patio-corral}

La casa, al menos en su último momento previo al abandono, se organizaba en torno a un gran patio (estancia 1), con unas dimensiones de $15 \mathrm{~m} \times 12 \mathrm{~m}$, que conformaba así un área abierta de unos $180 \mathrm{~m}^{2}$, aproximadamente, delimitada al norte por las estancias 3 y 4; al este por el zaguán y las estancias 2 y 5 ; al sur por un muro que la separaba de la calle meridional; y al oeste por la casa 15 (Fig. 4).

No hemos excavado el depósito estratigráfico que colmata el patio; tan solo hemos despejado la mayoría de las piedras caídas del nivel superficial y excavado también parcialmente este estrato inicial en estrechos sectores situados frente a las crujías norte y este. No obstante, los afloramientos rocosos que se aprecian en la parte septentrional del patio parecen indicar que la superficie de este espacio probablemente no presentaba una cota uniforme,
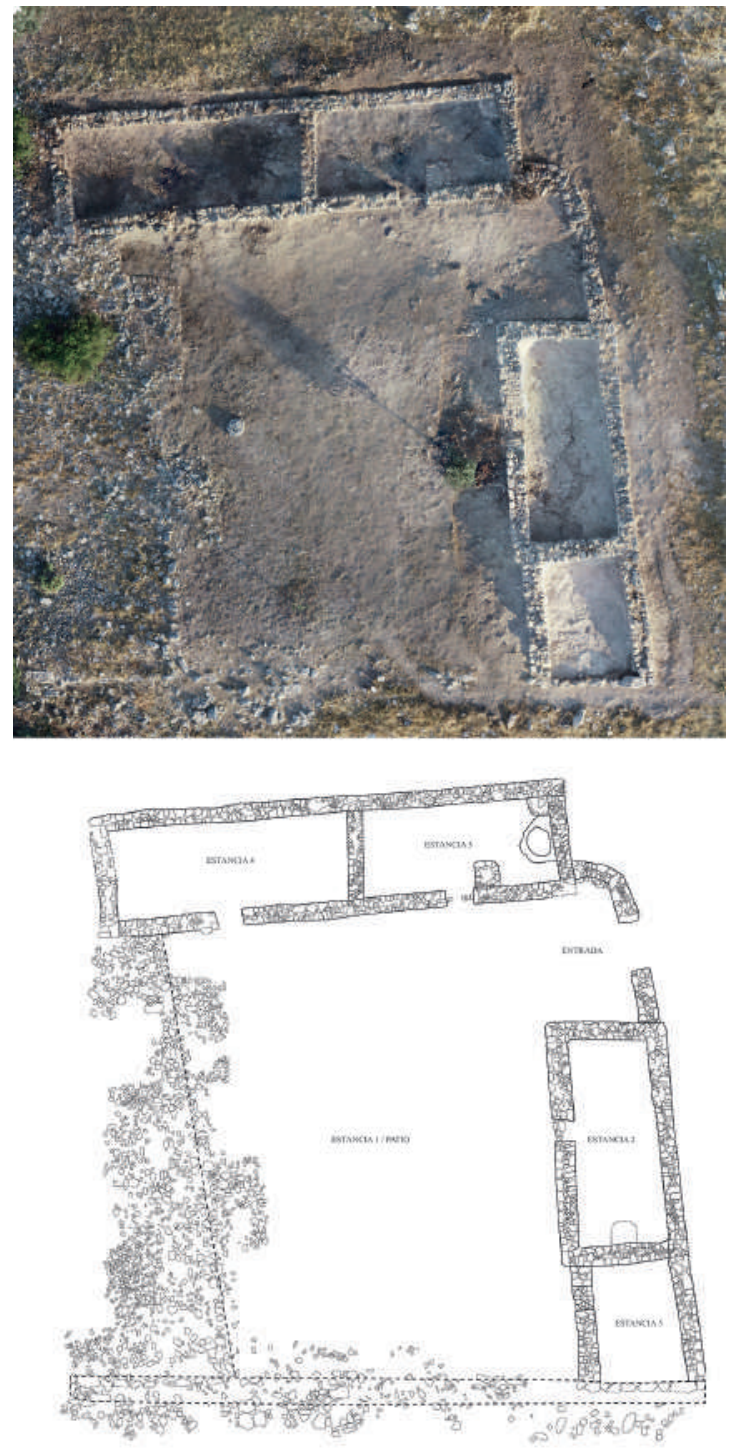

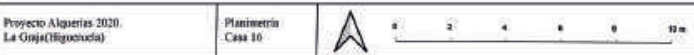

Fig. 4. Planimetría y fotografía aérea de la casa 16.

sino que tendría una cierta pendiente hacia el sur de acuerdo con la inclinación natural de la ladera, aunque esta cuestión solo podrá ser confirmada cuando se excave en extensión. De hecho, la pendiente ayudaba a la gestión y recolección del abono en un contexto de estabulación controlada del ganado como el que nos ocupa. Precisamente, la excavación de esas escuetas zonas en las que alcanzamos los niveles de suelo del patio nos permitió comprobar que sobre ellos se da un horizonte de desechos o residuos asociado a la fase de abandono de la casa en el que aparece la cantidad mayor de cerámica, dispersa y sin unión, en un contexto general de escasez de material arqueológico. 
En el cuadrante noroccidental del patio, aproximadamente frente a la puerta de entrada a la estancia 4, encontramos durante la campaña de 2021 un silo de sección piriforme, excavado en la roca base, que sin duda estaba destinado al almacenamiento de grano y que en la actualidad está en proceso de estudio.

Delimitados los muros de fachada de las estancias hacia el patio, pudimos comprobar que las crujías septentrional y oriental no se extendían por el ángulo NE de la casa, de manera que allí se generó un espacio de $4 \times 4$ $\mathrm{m}$ aproximadamente al que se abre la puerta de acceso a la vivienda desde la calle, por lo que estaríamos ante una suerte de zaguán descubierto o apéndice del patio que servía de transición entre el exterior y el interior.

El vano de entrada al complejo doméstico tiene 1,6 m de luz, anchura considerable que contrasta con la de los vanos de acceso a las estancias, lo que podría indicar que estaba destinado al paso no solo de personas y caballerías, sino también de pequeños rebaños de ovejas y cabras (Figs. 5 y 6). Lo delimitaban jambas conformadas por sendos ortostatos de dimensiones mayores a las habituales y dispuestos en horizontal, como suele ser habitual en los vanos de este tipo de arquitectura. Tal vez contaba con una puerta de doble hoja, aunque no hemos podido documentar quicialeras que aclaren esta cuestión.

El vano divide el muro en el que se abre en dos tramos: el septentrional, que presenta un trazado ligeramente curvo poco habitual en esta arquitectura caracterizada por la disposición ortogonal de las estructuras, entesta contra la esquina SE de la estancia 3; mientras que el tramo sur lo hace contra la esquina NE de la estancia 2. Ambos tramos de muro fueron construidos después que los de las crujías norte y este contra los que acometen, lo que parece demostrar que en una fase previa el patio no estaba cerrado por este ángulo. La disposición del ingreso al interior de la casa desde el exterior también refuerza esta hipótesis puesto que este era esquinado, pero no acodado, lo cual es también característico del tipo doméstico

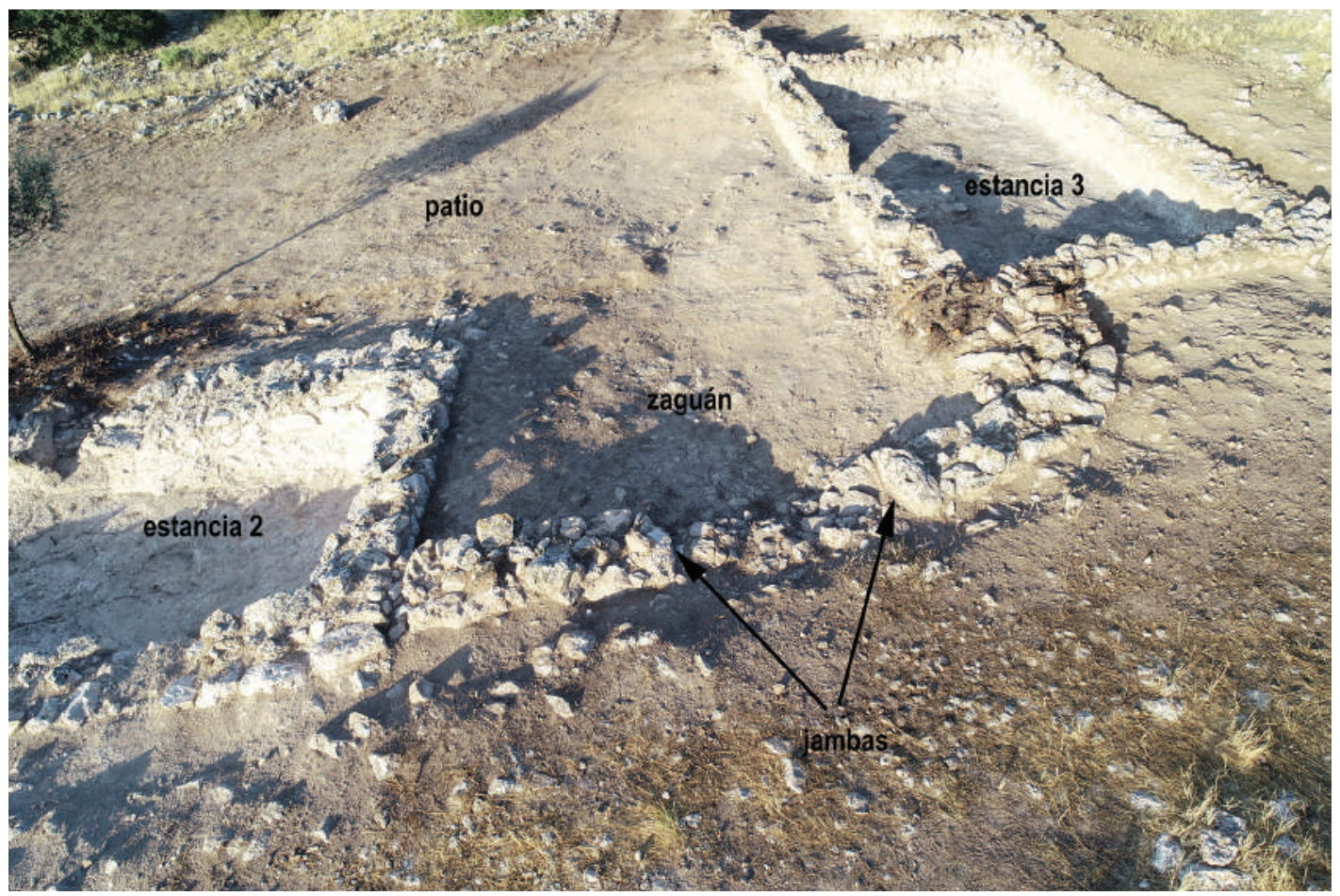

Fig. 5. Puerta de entrada a la casa desde el exterior y área del zaguán. 

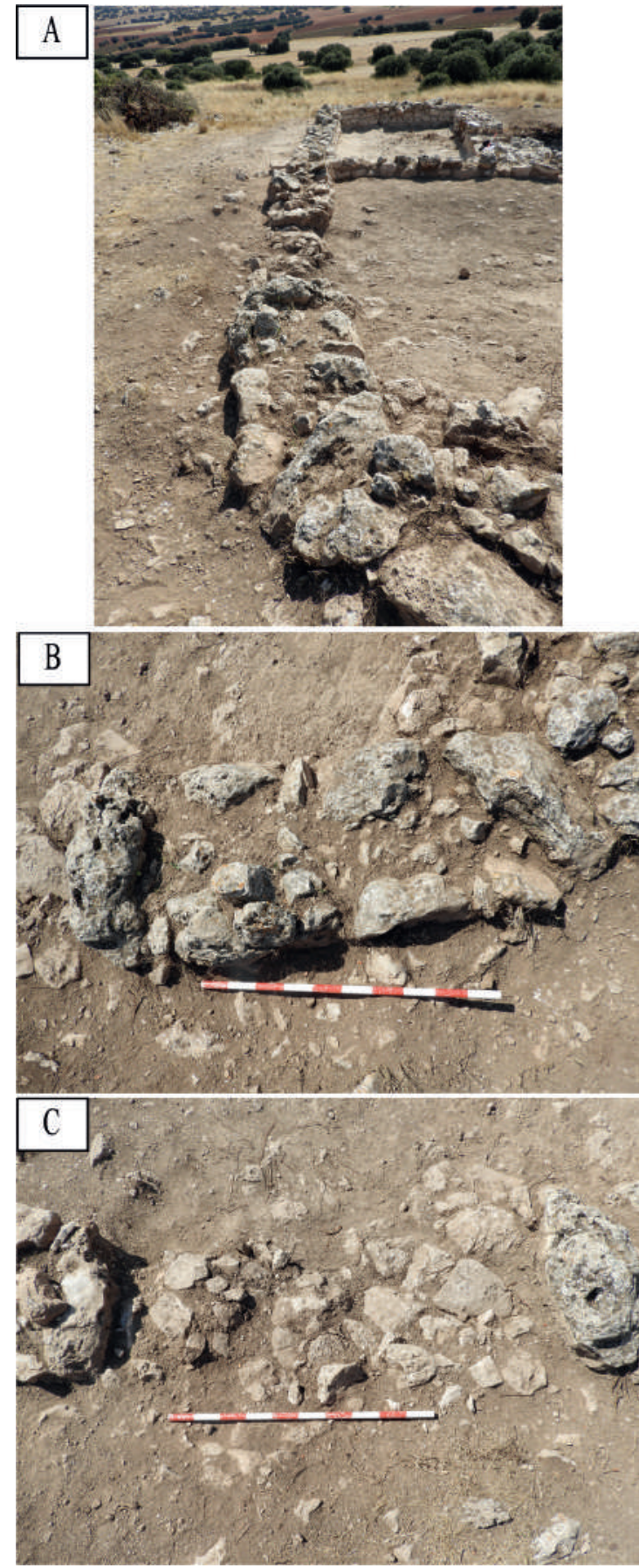

Fig. 6. A- Frente este de la casa. B- Detalle muro entrada. C-Entrada a la casa.

compuesto por módulos agregados delimitando un "protopatio», a diferencia de lo que sucede en el modelo de casa de patio central que se caracteriza por la presencia de zaguanes en recodo (GUTIÉRREZ, 2012: 147 y 148).

El patio ocupaba una parte proporcionalmente muy elevada de la superficie total de la vivienda, mucho mayor que la habitual en las casas andalusíes que conocemos de medios urbanos como medinas y husūn. Conviene recordar que este tipo de patio es el que hallamos en la mayor parte de las casas restantes de La Graja, según revelan los restos que se distinguen en superficie, así como en las viviendas de las otras alquerías análogas que hemos documentado mediante prospecciones en la comarca del Corredor de Almansa; creemos que la razón de que presenten estas características es que esos espacios desempeñaban una función esencial como corrales, según deducimos a partir de algunos indicios. Ya hicimos mención a la luz del vano de acceso al patio desde la calle, que resulta completamente excesiva si solo sirviera para facilitar el paso de personas y caballerías. Además, existen paralelos etnográficos: los cortijos tradicionales que salpican la zona presentan patios similares a los que nos ocupan en cuanto a organización y proporción, debido a que se suelen emplear como refugio temporal para los animales. Pero quizás la prueba más decisiva al respecto se puede derivar de la cotejación con los escasos ejemplos que conocemos de casas rurales andalusíes de la misma época, pero situadas en contextos físicos y productivos diferentes, como las de la alquería de Foietes (s. XI) en Finestrat, que pertenecían a campesinos cuyos recursos principales procedían de la agricultura de regadío. Las plantas de estas viviendas se organizaban en torno a espacios abiertos proporcionalmente menores que los de La Graja, que debieron de servir para las funciones propias del patio central y no como corrales, aunque se trata de una arquitectura que no deja de ser rural dado que no se distinguen tampoco salones o letrinas (GARCíA, LLORENS, PÉREZ, 2004: 90). Las mismas características que las casas de Foietes presentan las de Alcaria Longa, en Mértola, situada al pie de una fértil vega: "here, the valley widens into a small alluvial plain and the soil is deeper, moister, and less rocky. Today this area has orchards and gardens, and there are two water mills (now out of use) on the nearby creek bank" (BOONE, 1992: 53); mientras que se asemejan a las viviendas de los núcleos albaceteños que 
venimos estudiando las del hișn y la alquería de Jolopos, en las montañas granadinas, un territorio en el que "'agriculture irriquée, de toute évidence ne constituait pas ici la base de l'économie" que era "à dominante sylvo-pastorale” (BERTRAND, SÁNCHEZ, 2002: 155).

Las casas de los agricultores de Foietes contaban con establos, que suelen identificarse con facilidad por la presencia de pesebre y por su emplazamiento próximo a la puerta de entrada a la casa (JIMÉNEZ, 2013: 900-905); estas dependencias, sin embargo, están ausentes en La Graja, lo que sería otra prueba indirecta de que el patio servía para estabular animales, de manera que no era necesario habilitar un espacio particular para las caballerías. En resumen, creemos que también en la arquitectura rural andalusí del territorio de Chinchilla que venimos estudiando, el espacio central no solo servía para airear e iluminar las dependencias que a él se abrían o para realizar determinadas tareas domésticas, sino que también debió de emplearse para guardar ganado, por lo que sería apropiado denominarlo patio-corral. Más allá de los indicios comentados, seguramente conseguiremos pruebas decisivas al respecto cuando se acometa la excavación del patio y podamos efectuar análisis de la micromorfología del suelo y examinar el tipo de sedimentos que lo colmatan: si estos son más o menos orgánicos o incluso si contienen fitolitos, evidencias que podrían confirmar la hipótesis expuesta.

\subsection{La crujía norte}

La crujía septentrional está dividida en dos dependencias rectangulares: la número 3 al este y la 4 al oeste; la primera de ellas fue excavada hasta el nivel del pavimento, mientras que la segunda fue solo parcialmente exhumada.

La estancia 3 es una pieza oblonga de 6,9 m (este-oeste) $\times 3 \mathrm{~m}$ (norte-sur); por consiguiente, tiene una extensión de unos $21 \mathrm{~m}^{2}$.
Está cerrada por todos sus lados salvo por el sur, en donde se abre un vano de acceso de $1 \mathrm{~m}$ de luz que lo comunica con el patio. Una vez retirado el nivel superficial, procedimos a excavar en el interior de esta habitación un potente estrato de cascotes y piedras mezcladas con tierra marrón oscura, resultado de la ruina de los muros de mampostería, que proporcionó escaso material arqueológico. Cubría a otros dos niveles: el primero, más potente en los márgenes que en centro de la habitación, se componía de tierra marrón clara con restos procedentes de la descomposición de los morteros y revestimientos de los muros. Tras la excavación de las capas de escombro apareció en prácticamente toda la estancia un estrato bastante horizontal de tierra marrón oscura, suelta, con abundantes nódulos disgregados de mortero de cal que cubría directamente el suelo. Sobre este encontramos diferentes piezas cerámicas, entre las que destacan un fragmento de base de ataifor vidriada y una olla tipo "valenciano", así como una hoja de cuchillo de hierro. Aparecieron abundantes carbones dispersos por todo el horizonte, de los que se tomaron diferentes muestras para flotación y su caracterización cronológica y antracológica ${ }^{18}$. La habitación está solada con un mortero de cal pobre que se ha utilizado también para enlucir las paredes, al menos los zócalos, que se relacionan con el pavimento mediante una escocia robusta hecha con mortero de tierra y cal.

Al excavar estos niveles de desecho y combustión, apareció un hogar de planta circular (1 m de diámetro) adosado a la parte central del muro de cierre oriental y a un poyete que describiremos a continuación (Fig. 7A). Estaba conformado por una media caña hecha con algunas piedras y arcilla anaranjada y compacta por efecto del calor, que tenía un grosor medio de $5 \mathrm{~cm}$ de ancho $\times 5 \mathrm{~cm}$ de alto. Al interior de la misma se dispuso una torta de mortero muy bien alisado con huellas de fuego intenso. La presencia de este hogar explica, lógicamente, el nivel antes descrito

18. El estudio preliminar realizado por Mónica Ruíz Alonso (UGR) apunta a una alta presencia de pinus y leguminosae entre el material de construcción y uso para la combustión del hogar. 

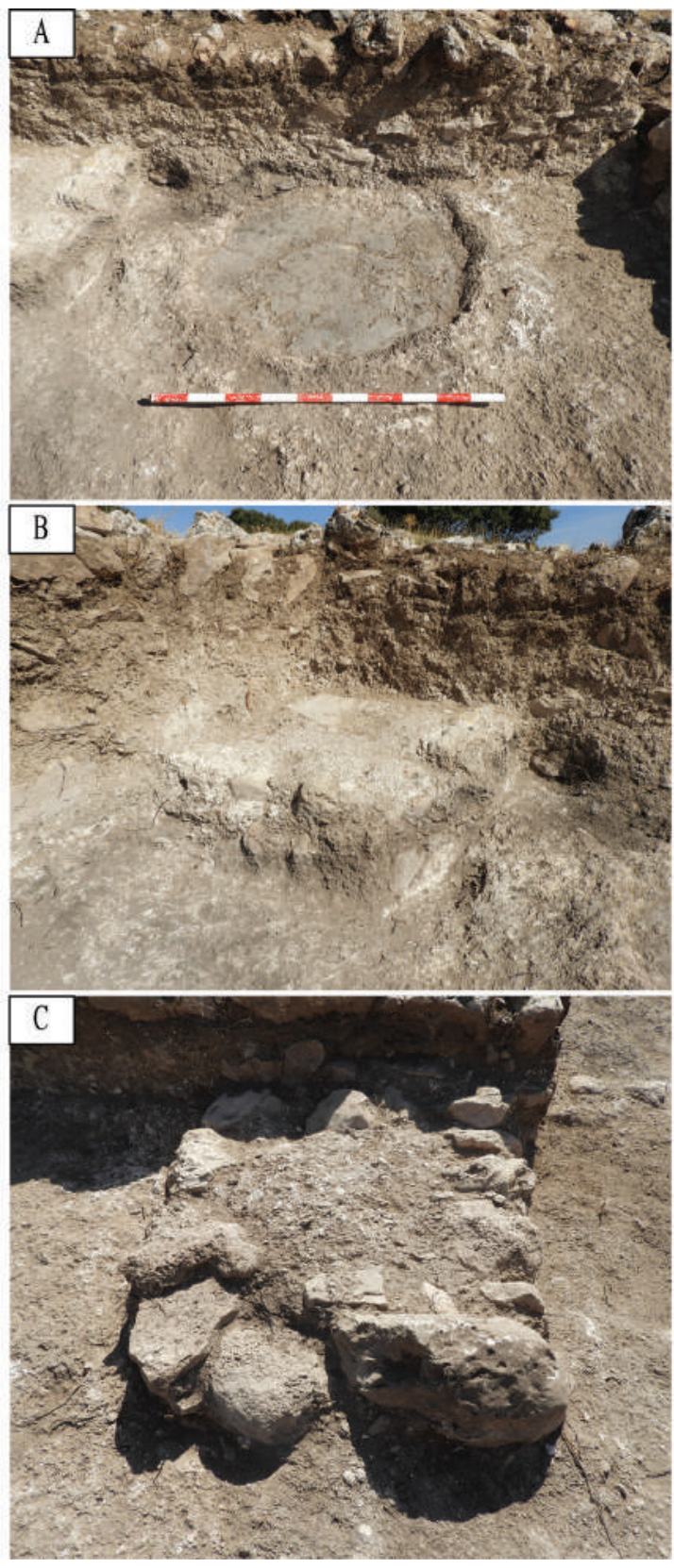

Fig. 7. A- Hogar. B-Poyo nororiental. C-Estructura junto a la puerta.

con abundantes cenizas y carbones, que estaría conformado en gran medida por residuos de la combustión en el mismo.

Ocupando el ángulo NE de la pieza, adosado al hogar, se encuentra un poyo bajo con planta de sector de círculo, construido con mampostería y argamasa; se proyecta unos 40 $\mathrm{cm}$ y tiene una altura conservada de entre $20 \mathrm{y}$ 30 cm (Fig. 7B). Debió de estar en relación con las diferentes funciones, especialmente asociadas a la preparación y cocción de alimentos, que se desarrollarían en el hogar anexo. Este tipo de elementos era muy común en las cocinas andalusíes, como se puede comprobar, por ejemplo, en los yacimientos de Siyāsa (Cieza) (NAVARRO, JIMÉNEZ, 2007: 232-236), el Tolmo de Minateda y Villa Vieja (Calasparra), en donde todas las cocinas disponen de hogar y poyo, así como frecuentemente también de alacena.

De construcción similary de planta rectangular, apareció otra estructura situada justo al este de la puerta de entrada, adosada al muro, formada por 1-2 hiladas de mampostería de mediano tamaño y un relleno de mortero blanco compacto (Fig. 7C). Tiene unas medidas de $0,8 \mathrm{~m} \times 0,4 \mathrm{~m}$, y una altura de entre 20 y $30 \mathrm{~cm}$. Su función resulta indeterminada; creemos que pudo servir igualmente como poyo o como plataforma sobre la que disponer grandes recipientes de almacenamiento como las jarras y las orzas, o bien como lugar de trabajo.

En resumen, la estancia 3 es, de todas las documentadas hasta ahora, la que presenta una definición más clara de la función a la que estaba destinada, pues existen pruebas indiscutibles de que estamos ante la cocina: así lo acredita la capa de cenizas que cubría el suelo, la presencia de un hogar y un poyo en el extremo oriental de la pieza y el hallazgo de fragmentos de ollas, alguna completa, sobre el pavimento. Además, se distingue como lugar destacado para la preparación de alimentos, si tenemos en cuenta que todas las estructuras (2 poyetes y el hogar) se concentran en el lado este, quedando el oeste completamente diáfano para funciones de trabajo. Queda por definir la función del espacio sin estructuras en la parte oeste de esta estancia, quizás ligado también a la preparación de alimentos u otras actividades que no hemos podido determinar.

Al oeste de la anterior, se encuentra la estancia 4, de planta también oblonga $(7 \times 3 \mathrm{~m})$ y a la que se accede desde el patio mediante una puerta que tiene $90 \mathrm{~cm}$ de luz. La estratigrafía del interior de esta habitación, hasta donde documentamos, es similar a la de la $n^{0} 3$ : bajo el nivel superficial aparecía otro de escombro 
compuesto por piedras grandes y medianas asociadas a una tierra marrón oscura, producto de la ruina de los muros perimetrales; este cubría a una capa de tierra marrón clara, suelta, con restos blanquecinos de mortero de tierra con cal procedentes de los revestimientos desprendidos de los muros perimetrales; en la parte central se extendía una capa de tierra marrón oscura con algo de mampostería. En el extremo oriental de la misma se conservan dos tabiques bajos (unos $40 \mathrm{~cm}$ ) construidos con mampostería tomada con el característico barro hecho con las margas grisáceas del lugar, que proporcionan una cierta plasticidad a la masa. Se trata de un soporte sobre el que se disponía la tarima de madera del lecho, que de esta manera quedaba separado del suelo mediante una cámara aislante; un elemento cuya existencia está bien documentada en numerosos ejemplos de viviendas andalusíes (Jiménez, 2013, 946-951). A la luz de lo expuesto, parece fuera de duda que estamos ante un salón, dependencia multidisciplinar que acogía en sus extremos a las alhanías o alcobas en donde se dormía, que además está situado canónicamente en la crujía norte.

\subsection{La crujía este}

Está dividida en dos habitaciones desiguales que se abren al patio mediante sendos vanos: la $n^{0} 2$ al norte y la $n^{0} 5$ al sur. Dado que esta crujía se extiende en perpendicular a la dirección de la pendiente, para poder conseguir un nivel de suelo horizontal en el interior de las habitaciones parece haber sido necesario rebajar la superficie rocosa natural en el extremo norte de la crujía, tal y como revela el análisis del alzado de sus muros longitudinales (Fig. 8).

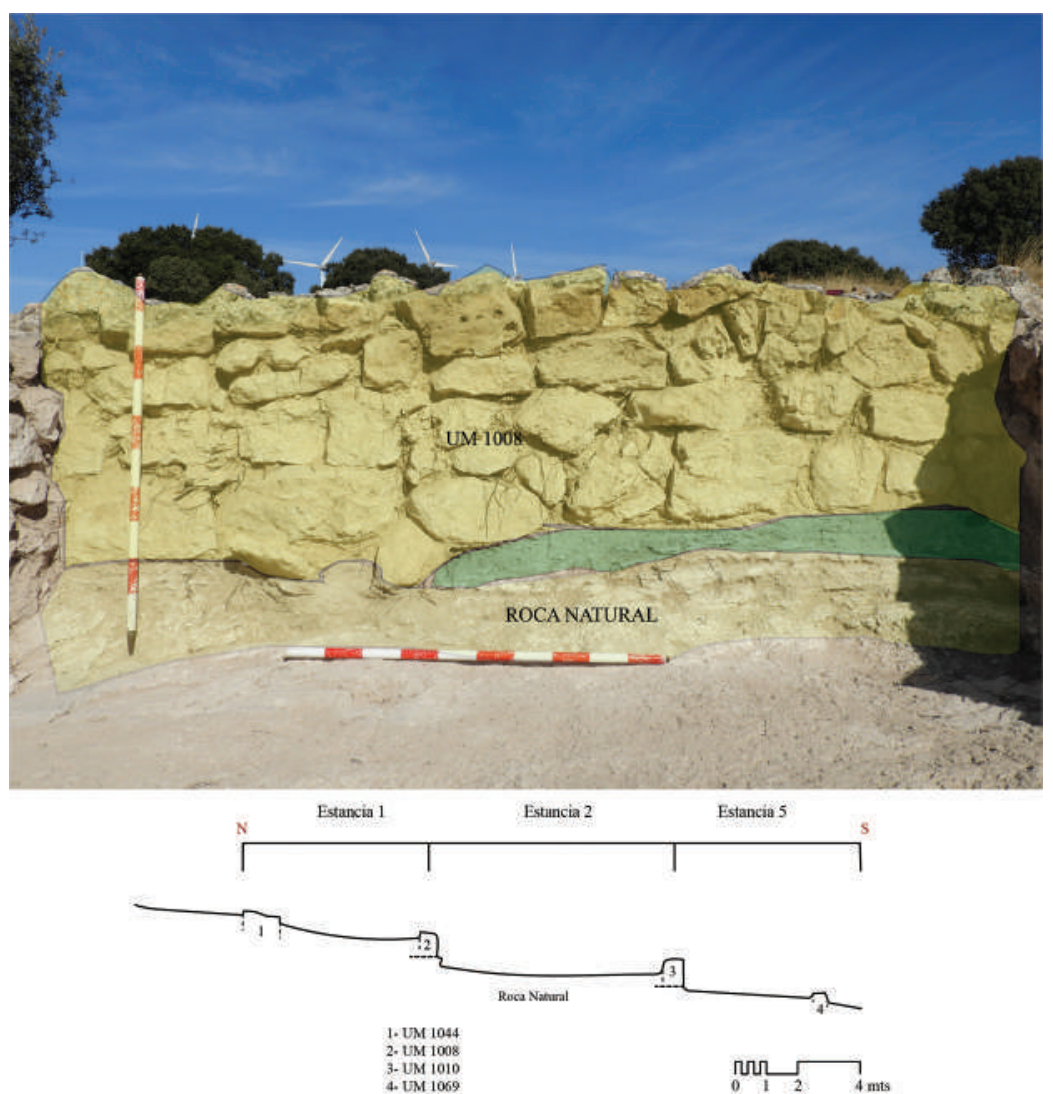

Fig. 8. Estancia 2. Detalle constructivo del muro occidental (a la izquierda se distingue la jamba norte del vano que comunica la estancia con el patio). 
La estancia 2 es la más septentrional y mayor de las dos que ocupan la crujía oriental. Se trata de una pieza oblonga de $7 \times 3 \mathrm{~m}$ (21 $\mathrm{m}^{2}$ de superficie), comunicada con el patio a través de una puerta de $80 \mathrm{~cm}$ de luz. Tras retirar el nivel superficial, apareció por todo el espacio un potente estrato de escombro de más de $1 \mathrm{~m}$ de potencia, formado por piedras de mediano y pequeño tamaño, resultado del colapso de los muros perimetrales. Contenía algunos fragmentos de tejas y muy poco material cerámico. Por debajo de este estrato se halló otro nivel, más potente, junto a los muros perimetrales, en el centro del espacio, formado por mampuestos junto con tierra compacta de tono claro con numerosas inclusiones blancas, que creemos se debe relacionar con los paquetes sedimentarios de margas disueltas (calcitas y arcillas) propias de esta zona, que se usaron para mezclarlas en los muros como aglutinante.

El suelo de la habitación 2 parece haber estado a una cota algo más baja que la del patio, diferencia que se salvaba mediante un escalón inscrito en el propio vano. El suelo estaba conformado por la propia base de piedra retallada y se completaba con aportes de tierra pisada, sobre todo en el extremo sur de la pieza; también se detectaron diferentes reparaciones parciales consistentes en capas de tierra que se mojaban y apisonaban alcanzando así la consistencia necesaria.

Sobre el suelo de esta habitación, en el centro de su extremo sur, se detectó una mancha de tierra quemada de unos $40 \mathrm{~cm}$ de diámetro que creemos podría indicar que en algún momento allí se estableció un hogar o quizás un horno portátil o atanor (ár. tannūr) ${ }^{19}$, aunque sería esporádicamente o, al menos, no estaría en uso en la última fase porque en esta estancia no existía la extensa capa de ceniza que hallamos en la habitación n 3 . Al igual que sobre el suelo de esta última, hallamos una olla completa en el nivel de abandono y una jofaina casi entera de base plana con cubierta vítrea interior melada, así como parte del fondo de un ataifor decorado en "verde y morado"; en ambos casos piezas asociadas al servicio y presentación de alimentos.

La estancia 5 está situada en el extremo sur de la crujía oriental; es la menor de las documentadas pues mide $4 \times 3 \mathrm{~m}$ (Fig. 9). Como en los casos precedentes, la estratigrafía arrancaba con el nivel superficial que cubría un potente estrato de escombro, sin apenas material arqueológico, bajo el que se documentó una capa de tierra marrón claro, de textura arenosa, blanda y suelta, con piedras de pequeño tamaño e inclinación norte-sur, a la que se asociaba algo de cerámica. Este nivel cubría directamente el suelo de la estancia, que al igual que sucedía en la estancia 2, estaba conformado por el sustrato geológico, es decir, la propia roca natural recortada y regularizada con aportes de tierra apisonada en donde era preciso. También se detectó una estructura de hogar muy desgastada que se adosaba al muro sur; era de tipo torta, similar al hallado en la estancia 2, con un ligero reborde muy fragmentado. No apareció ningún desecho asociado por lo que creemos que su funcionamiento fue esporádico. No hay evidencias que permitan conocer a qué función (o funciones) estaba destinada esta pieza, aunque es necesario resaltar que en su interior y directamente sobre el suelo, se halló una aguja de bronce que estaría asociada a trabajos textiles, actividad que también está probada por el hallazgo de un dedal, hecho en aleación de cobre, sobre el suelo del patio.

La estancia 5 se comunicaba con el patio mediante una puerta de $55 \mathrm{~cm}$ de luz que excepcionalmente no estaba en el centro del muro, sino que se hallaba sensiblemente desplazada hacia el norte (Fig. 10). La puerta fue bloqueada con piedras medianas en el momento en que se abandonó la vivienda; un cegamiento que lógicamente se efectuó desde el patio, razón por la cual en ese frente exterior

19. Del término árabe deriva el español "atanor" que significa "tubo cerámico" aunque también "horno de alquimista"; seguramente la palabra árabe designaba por igual al tubo para cañería y al horno, dado que ambos eran cilindros o abiertos por ambos extremos. Por consiguiente, creemos que no es incorrecto emplear la palabra española "atanor" para nombrar también este tipo de hornos portátiles de forma troncocónica y abiertos por arriba y por abajo. 


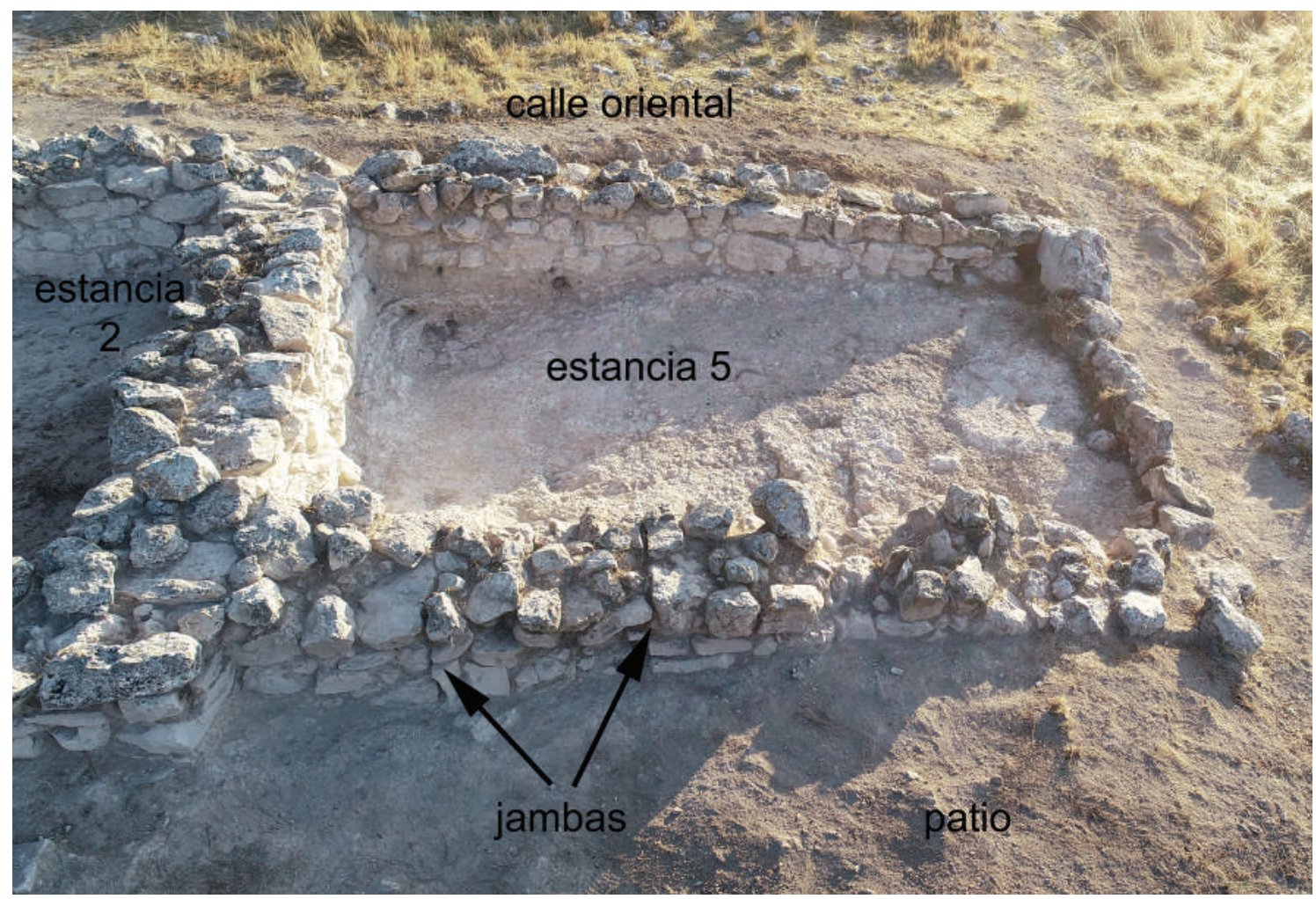

Fig. 9. Estancia 5, vista desde el patio. En la parte superior de la imagen estaría la calle oriental.

de la obra aparece la mampostería careada pero no así en el interior. Este tipo de cerramientos ha podido ser documentado en las casas de otros yacimientos andalusíes de cronología diversa, como por ejemplo el Molón de Camporrobles (Valencia) o Siyāsa (NAVARRO, JIMÉNEZ, 2007, Figs. 54 y 55), asociándose normalmente a acciones encaminadas a evitar la ruina de las casas en el momento de ser abandonadas, lo que de paso prueba que sus dueños tenían alguna esperanza de volver a hacer uso de ellas.

\subsection{Los límites sur y oeste}

El frente sur de la vivienda está delimitado por un muro que, sin solución de continuidad, cierra por ese lado la habitación 5 y el patio. En esta campaña pudimos documentar el tramo más oriental del mismo, el que delimita la mencionada estancia, pero no pudimos excavar el sector del patio, por lo que acerca de este no tenemos más información que la de los restos que se aprecian a nivel superficial. El muro en cuestión presenta la misma fábrica que el resto de los de esta vivienda, es decir, dos paramentos compuestos por mampostería mayor entre los que se dispone un relleno de ripio. No parece que la estructura sea más potente que la que delimita otras habitaciones, a pesar de que en este caso funcionaría también como muro de contención al delimitar la parata o plataforma sobre la que se extiende la vivienda por la parte inferior de la ladera.

Debido a esta circunstancia, en el tramo excavado se ha podido comprobar que el muro cedió y se desplazó ligeramente hacia el sur, incluso desprendiéndose la mayor parte del paramento exterior y conservándose solo el que da al interior de la estancia. Dado que, según hemos dicho, no se ha podido excavar en toda su extensión este cierre de la casa, ni mucho menos intervenir más allá de este límite, no podemos asegurar que al sur del mismo no pudiera haber algún tipo de dependencia o crujía vinculada a la vivienda. Ciertamente, los restos que se aprecian en superficie no parecen apuntar en este sentido puesto que lo que existe al otro lado del muro es un desnivel que vendría a corresponder con la cota más baja de la calle que corre por el sur; no obstante, el ancho de la calle medido 

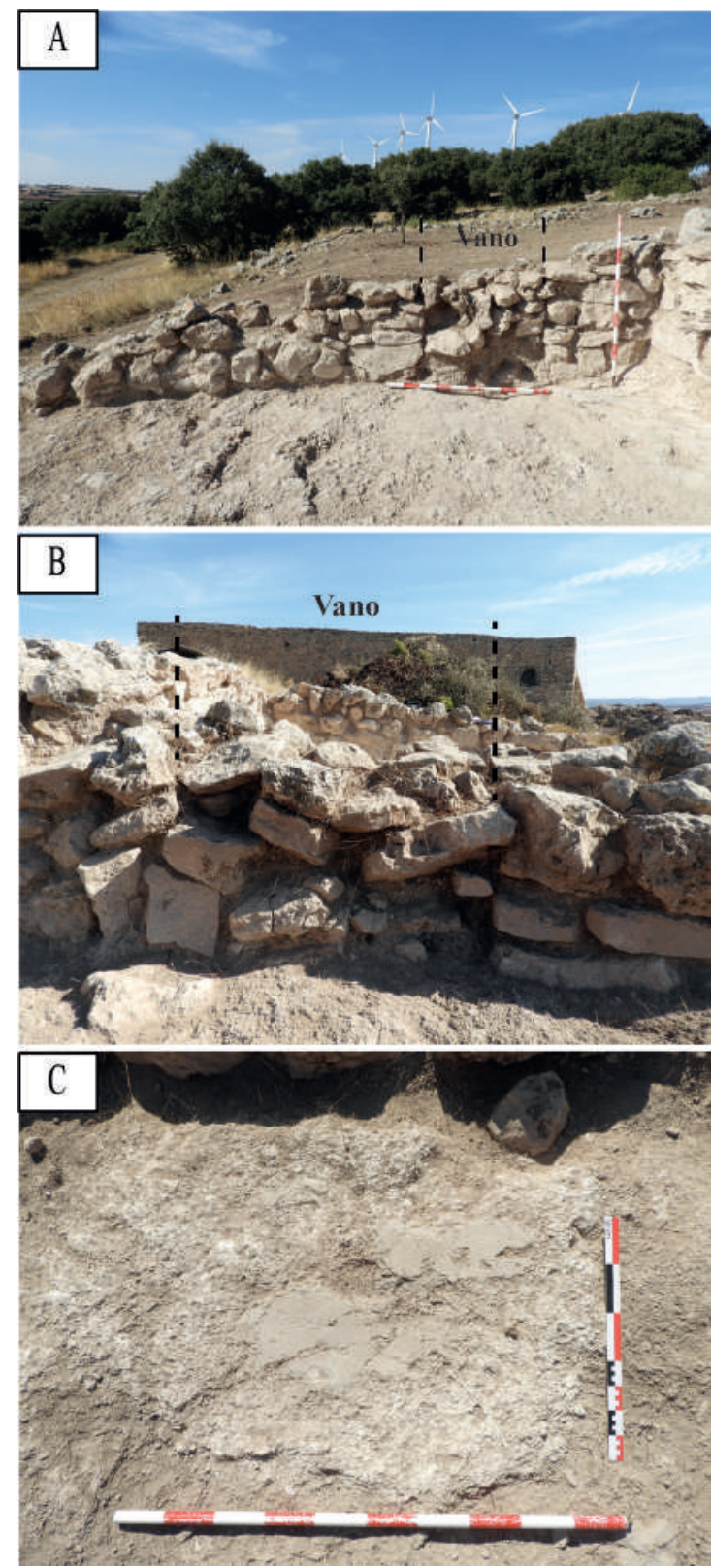

Fig. 10. A-Muro oeste de la estancia 5. B- Detalle de tapiado del vano. C-Hogar.

entre el límite de la casa que nos ocupa y el muro de fachada de la vivienda situada al otro lado es de 6-7 $\mathrm{m}$, anchura suficiente para que sea posible la existencia de una crujía en este frente de la casa 16, que necesariamente tendría que estar a una cota inferior a la del patio. En cualquier caso, estas cuestiones solo podrán ser resueltas en el transcurso de la próxima intervención arqueológica.
El muro que limita el patio por el oeste ha podido ser documentado en toda su extensión durante la campaña de 2021, gracias a lo cual sabemos que llegaba por el sur hasta el límite antes comentado pero por el norte no cerraba contra la crujía, sino que doblaba en ángulo de 90 grados hacia el oeste, conformando así un espacio que parece haber servido como corredor de comunicación con el núcleo doméstico que hemos denominado casa $n^{0} 15$. Aunque dicho paso parece haber sido clausurado por una obra de mampostería, todo parece indicar que ambos patios formaron parte en su momento de una sola propiedad. Dado que aún no hemos excavado el edificio 15, habrá que esperar a próximas campañas para establecer la relación entre ambos núcleos y su evolución constructiva.

\subsection{Materiales y técnicas constructivas}

El ancho de los muros de la casa 16 es bastante uniforme, y oscila entre 50 y $60 \mathrm{~cm}$. Sus zócalos, de hasta $1 \mathrm{~m}$ de altura aproximadamente, que es lo que se ha conservado una vez excavados, están básicamente levantados con mampostería dispuesta mediante dos caras o paramentos, entre las que se aloja un relleno de ripio y cascajo. Las piedras, de mayor tamaño en las hiladas inferiores, estaban tomadas con un mortero conformado básicamente por barro y una pequeña cantidad de cal: según el informe arqueométrico por macroscopía de las argamasas:

"estamos ante fábricas poco elaboradas, con una ejecución tosca o tal vez, apresurada, y con unos resultados, sobre todo por el uso del aglutinante, que hablan de emplastos recubriendo paredes de uso agropecuario, o rejuntando mamposterías toscas provisionales. Estas técnicas se han documentado en todo tipo de asentamientos, no solo de cronología antigua sino reciente, y más en espacios de uso agrario"20.

La parte superior de los muros no se ha conservado, si bien parece que estaba compuesta igualmente por tierra y piedras, aunque

20. Pablo Guerra García, Arqueometría por Macroscopía de Argamasas Históricas. Informe final, 2021. 

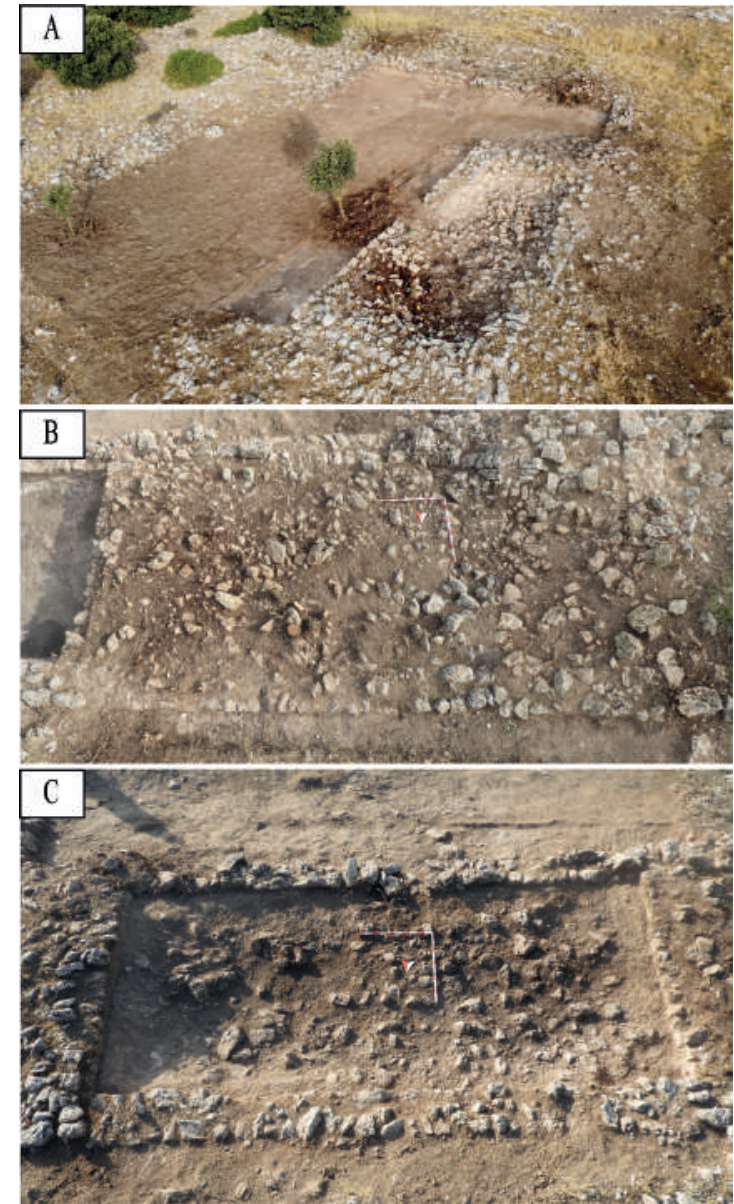

Fig. 11. Derrumbes de las estancias excavadas. AEstancia 2. B-Estancia 4. C-Estancia 3.

la proporción de la primera sería mucho mayor que la de los zócalos. Así se desprende de la composición de los niveles de derrumbe del interior de las habitaciones (Fig. 11), que presentan mucha más tierra en las capas próximas al pavimento (que corresponderían a las partes más altas de las paredes) y más piedra en las superficiales (que provendrían de los zócalos). Puede que estos alzados fueran encofrados, como es habitual en este tipo de arquitectura, aunque no tenemos datos que nos permitan asegurarlo. Tanto las esquinas internas y externas de la casa como las jambas de las puertas estaban reforzadas mediante bloques de mayor tamaño, ortostatos dispuestos en vertical en el caso de las que flanqueaban los vanos.
Dado que la vivienda se levantó en una ladera poco pronunciada, las habitaciones dispuestas en perpendicular a la pendiente, es decir, las de la crujía oriental, se nivelaron mediante la excavación parcial de la roca base, especialmente en el extremo norte. De esta manera, la parte inferior de los muros en esos sectores está conformada por la roca retallada sobre la que se dispuso una capa de tierra muy compacta que sirvió de base a la primera hilada de piedras. En estos casos, los suelos estaban conformados por la base rocosa o por capas de tierra apisonada, aunque en la estancia 3 se comprobó también la existencia de un pavimento de mortero de cal.

A juzgar por los paralelos etnológicos y arqueológicos que conocemos, las techumbres debieron de ser a un agua y estarían constituidas por faldones de rollizos sobre los que se dispondrían ramas ${ }^{21}$ y tierra en algunos casos y, en otros, tejas. La presencia de estas últimas es incuestionable, porque se han recuperado fragmentos de teja sobre los suelos de casi todas las dependencias; es verdad que son escasos y que no se han hallado piezas completas, pero esto creemos se debe a que fueron desmontadas para su reaprovechamiento en el momento de abandonarse la casa. Por consiguiente, actualmente defendemos la hipótesis, que deberá confirmarse o corregirse en futuras campañas, de que al menos las estancias principales pudieran tener teja y el resto tierra apisonada, solución que tiene paralelos etnográficos en la comarca.

Al igual que las tejas fueron reaprovechadas tras el abandono de la vivienda, también lo fueron los rollizos de madera que sostenían las techumbres, según demuestra el hecho de que las paredes colapsaron hacia el interior de las estancias puesto que, cuando se conservan esas vigas durante el proceso de ruina, atirantan la parte superior de los muros haciendo que estos se derrumben hacia el exterior. Estas reutilizaciones de materiales constructivos nos informan también sobre la naturaleza del proceso de abandono de esta

21. El estudio antracológico apunta a un uso constructivo de madera y leña de pino y leguminosas. 
casa y del yacimiento en general, pues se trata de elementos que no eran muy valiosos, o al menos no tanto como para que mereciera la pena el coste que suponía transportarlos a larga distancia. Esto significa que la despoblación de la alquería debió de llevar aparejado el crecimiento de algún asentamiento próximo y, presumiblemente, el traslado al mismo de una parte indeterminada de los habitantes de aquella.

La excavación de la casa 16 ha permitido documentar detalladamente las características de los aparejos empleados, que son idénticos, hasta donde podemos apreciar, a los del resto de los edificios de La Graja, así como de las demás alquerías de la región a juzgar por los restos constructivos en superficie. También son muy similares a los de las viviendas de las alquerías de Mora la Vieja y El Quemao (Teruel): en estas últimas encontramos de nuevo mampostería en doble paramento con relleno de piedras menores, mortero de barro y alzados de tierra, con piedras esquineras de mayor tamaño y jambas compuestas por piedras verticales. La mayoría de los suelos son de tierra apisonada y las techumbres de teja (ORTEGA, VILLARGORDO, 2020: 183-186). De todo ello cabe deducir que el aparejo y la técnica descritos serían comunes en todos los ejemplos de arquitectura rural andalusí, al menos en este momento. A diferencia de lo que sucede en La Graja, en El Quemao se han documentado zócalos pintados a la almagra sobre capa de yeso y suelos con idéntico acabado, lo que interpretamos como elementos arquitectónicos que denotan un cierto lujo y distinción que están ausentes en la casa n 16.

\subsection{Evolución de la casa}

Aparte de las consideraciones expuestas acerca de la relación del núcleo doméstico que nos ocupa con el n 15, la excavación arqueológica ha aportado indicios que permiten pensar que la casa 16 no fue levantada de nueva planta con la organización que hemos descrito, sino que es el resultado de una evolución constructiva: en un primer momento se edificaron las crujías, las dos a la vez o quizás primero la septentrional y luego la oriental, mientras que el patio se generó en una fase ulterior cuando se levantó el muro en el que se inscribe la puerta de entrada.

Esta hipótesis está avalada por la existencia en la alquería de La Graja de edificios domésticos conformados por una sola crujía, sin patio, del tipo que se viene denominando "monocelular", que podrían ser análogos a la primera fase de la casa 16. Todos ellos son de planta rectangular, con el eje mayor en dirección este-oeste y la puerta abierta hacia el sur, tal y como corresponde a las crujías septentrionales de las casas, por esa razón suponemos que, si efectivamente la casa 16 evolucionó como proponemos, la primera nave que se construyó sería la norte. La planta monocelular está bien documentada en yacimientos andalusíes por lo general algo más antiguos que La Graja, como El Molón (Camporrobles, Valencia), de los Ss. IX-X; o el Tolmo de Minateda (siglos VIII-IX) (GUTIÉRREZ, 2015: 22).

Tanto si en primer lugar se construyó la crujía norte y posteriormente la este, como si se edificaron las dos al mismo tiempo, lo que parece indudable es que en una fase previa a la última, la casa contó con dos naves que delimitaban un "protopatio" que acabó de cerrarse al construirse el muro del ángulo NE, de acuerdo con un proceso de formación de viviendas de patio central por agregación de crujías y muros perimetrales que ya ha sido documentado y estudiado en otros asentamientos análogos al que nos ocupa (GUTIÉRREZ, 2012: 147; 2015: 24-25). Esta evolución del modelo doméstico que en algunos yacimientos culmina en la casa de patio central, el tipo residencial islámico por excelencia en la Edad Media, no aconteció al mismo ritmo ni de manera sincrónica en todo al-Andalus sino que tiene que ver con la consolidación urbana de cada uno de los asentamientos en particular, como lo demuestra la existencia de estos modelos domésticos "arcaicos" en un yacimiento de cronología relativamente avanzada como La Graja. Además, 
en la fase final de esta alquería del siglo XI conviven casas mononucleares con otras dotadas de "protopatio", como la que nos ocupa, que parecen haberse configurado a partir de los modelos más sencillos debido al crecimiento natural de las propias familias y seguramente también al desarrollo de la alquería que generaba unas necesidades cada vez mayores en cuanto a intimidad, por lo que no creemos que el paso de plantas domésticas monocelulares a pluricelulares y patios centrales se pueda asociar a un proceso de islamización de sus moradores, al menos en el caso de La Graja. Este desarrollo paulatino de la vivienda que hemos descrito se diferencia de lo que se ha observado en El Quemao, en donde se construye primero el perímetro exterior de la casa y luego los muros de partición, lo que ha sido identificado por sus excavadores como evidencia de una planificación inicial de todo el espacio doméstico (ORTEGA, VILLAVERDE, 2020: 186).

El éxito del modelo residencial de patio central, el más característico de al-Andalus, tiene que ver esencialmente con razones asociadas a su aptitud para desarrollar estrategias destinadas a preservar la intimidad de sus moradores en un contexto social endogámico, de acuerdo con unas necesidades que son acuciantes en el medio urbano pero no en el rural, donde el vecindario es mucho más escaso y familiar, por tanto no se puede identificar de manera automática el tipo de casa monocelular con la familia nuclear y el de patio central con la familia extensa ${ }^{22}$. Para ello es necesario examinar otros indicios relativos al número y especialización de los espacios que componen la vivienda. En el caso de la vivienda 16, la organización y tamaño final de la vivienda, que incluía al menos 4 dependencias de grandes dimensiones, permite suponer que pudo acoger a más de una célula familiar, lo que no significa necesariamente que se deba asociar cada una de las estancias con una familia pues existen indicios suficientes para establecer una cierta distinción funcional en los espacios. Esto resulta especialmente evidente en relación con la estancia 3, que claramente podemos identificar como la cocina a partir de una serie de elementos y características que no se encuentran en ninguna otra de las estancias, así como con la 4, que es un salón con alhanía. No obstante, también hay huellas de hogares menores en los lados cortos de las dependencias 2 y 5, lo que podría sugerir la presencia de más de una célula conyugal que formarían parte de un grupo familiar extenso y que, unidas por esos lazos de parentesco, habrían cohabitado en la misma unidad doméstica.

\section{EL REGISTRO CERÁMICO}

Tal y como anunciaban las prospecciones, la cerámica recuperada durante la excavación arqueológica de La Graja es escasa, tanto en el estrato superficial como en el siguiente, conformado por el escombro de los muros. En este segundo, no obstante, se halló algo de material que era más abundante en los niveles de tierra procedente de la propia fábrica de los muros, que tal vez fuera encofrada como sucede en otros yacimientos próximos en tiempo y/o en el espacio en los que el aparejo constructivo parece similar, como la alquería de El Quemao o la rábita de Guardamar (Alicante). Estas cerámicas son fragmentos muy desgastados, que conservan una pátina blanquecina derivada de la naturaleza de as margas con que fueron amasadas; se trata por lo general de piezas de paredes bizcochadas y finas, ollas o jarritas sin cubierta vítrea ni decoración, que no pegan entre sí debido a que fueron acarreadas y las hallamos en deposición secundaria.

Aun siendo muy exiguos, los restos de objetos en general, y de cerámica en concreto, son sensiblemente más abundantes en el nivel de abandono que aparecía en contacto con los pavimentos (Fig. 12). En este caso, se han podido recuperar fragmentos

22. Discrepamos, por tanto, de Ortega y Villargordo (2020: 187) cuando afirman que "El resultado de esta forma de organizar el espacio doméstico fue la configuración de las típicas casas de patio interior, destinadas a servir de residencia a grupos familiares amplios, integrados por varias células conyugales sometidas a la autoridad de un patriarca". 

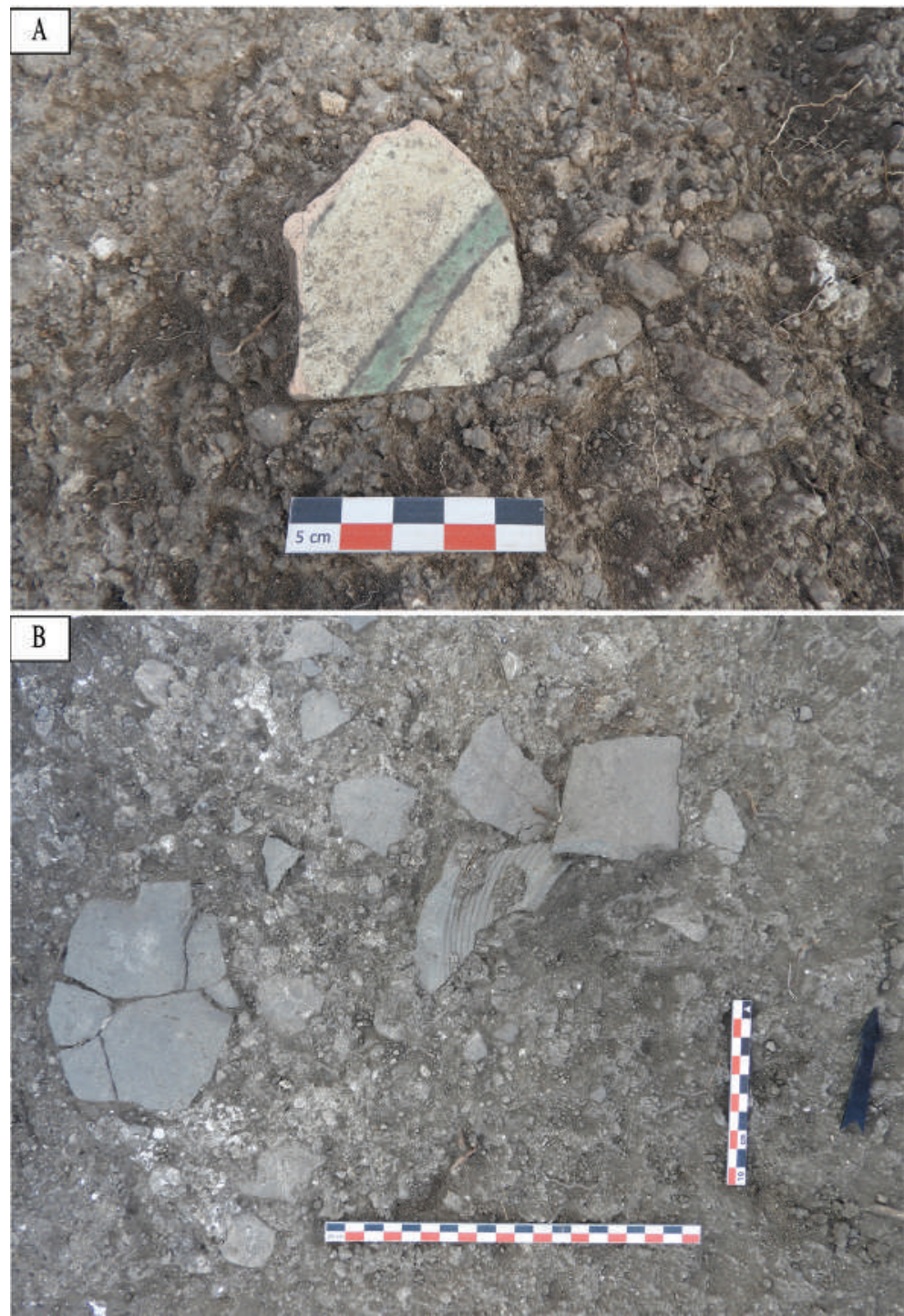

Fig. 12. Material cerámico sobre el suelo de la estancia 3. A-Ataifor verde-manganeso. B-Olla.

correspondientes a recipientes de diferentes tipos, incluidas algunas piezas completas, aunque lógicamente fragmentadas (Fig. 13).

En resumen, la estratigrafía y el análisis de los materiales revela que nos encontramos ante un conjunto de cerámicas que procede básicamente de dos momentos diferentes: la construcción de la vivienda, para la que se aprovecharon restos anteriores que fueron reutilizados en las fábricas de tierra de los muros; y el momento de abandono de la casa, al menos dos o tres generaciones después. No obstante, dado el carácter poco significativo del primer conjunto, las características del ajuar que ahora describiremos corresponden básicamente a las cerámicas del segundo grupo, por lo que la información cronológica que se desprende tendrá que ver con la fase en que la casa fue abandonada.

Además de la parvedad del conjunto de materiales hasta ahora recuperado, también llama la atención la humildad del ajuar de estas familias campesinas, en el que son muy escasas las piezas de lujo en cuanto a su función, decoración o acabado. Así lo podremos comprobar en esta aproximación a las producciones halladas, para la que nos apoyaremos en la clasificación funcional que tradicionalmente se viene empleando para la cerámica andalusí, que nos permitirá analizar los tipos que se dan y también nos permitirá detectar los que están ausentes. 

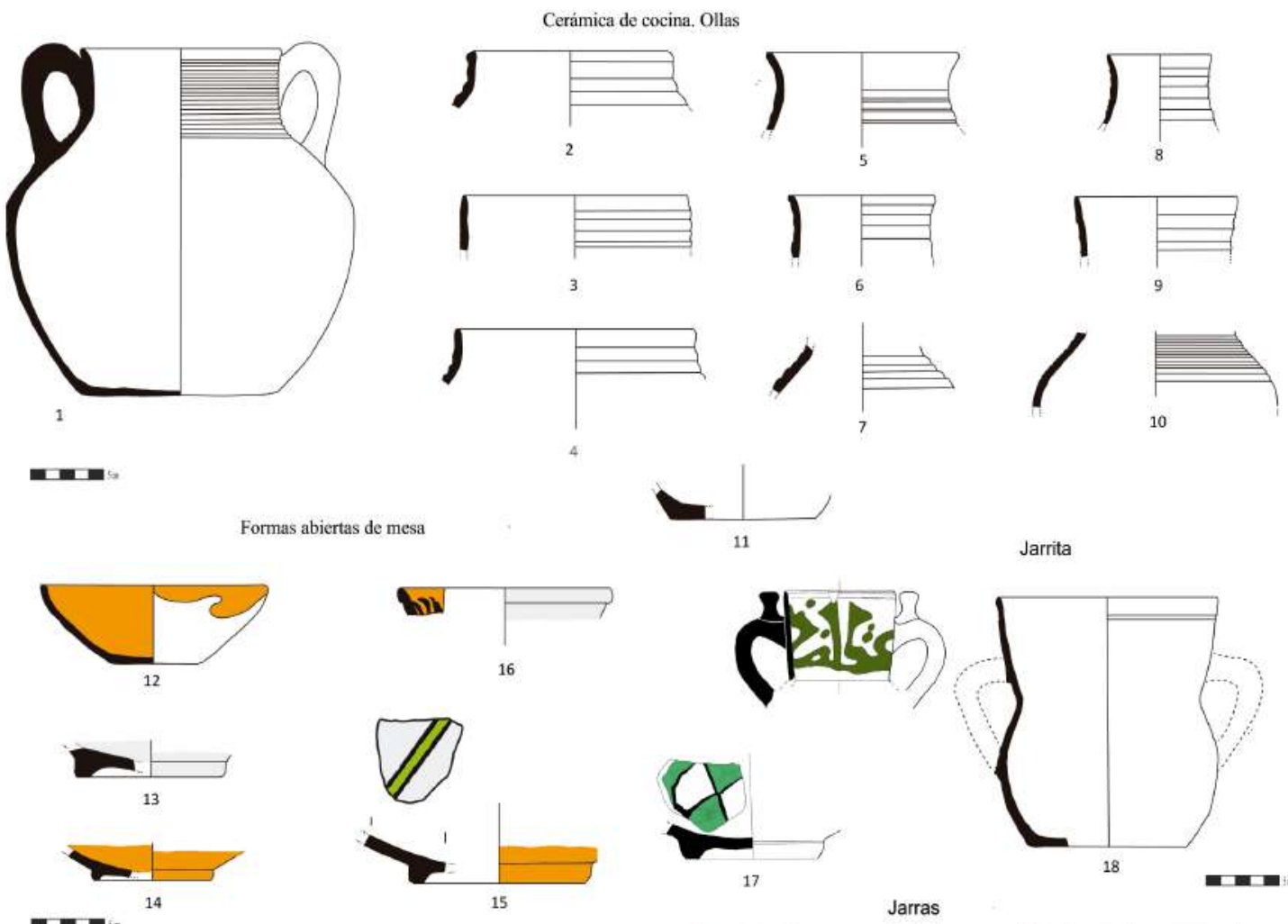

Redomas
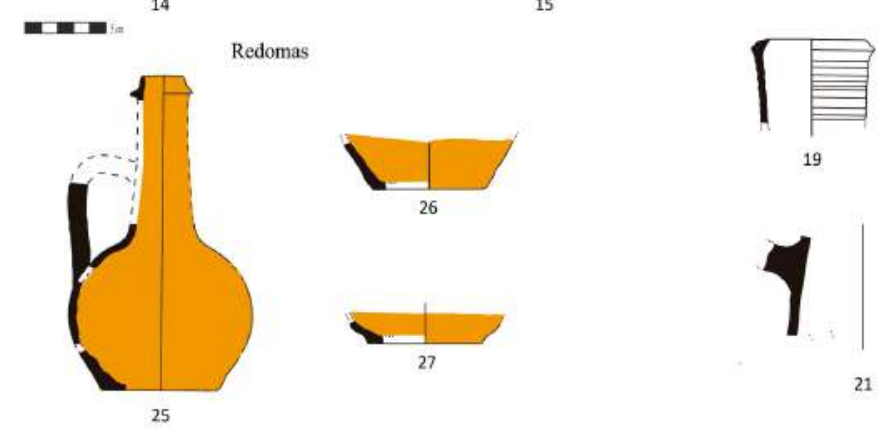

Jarras
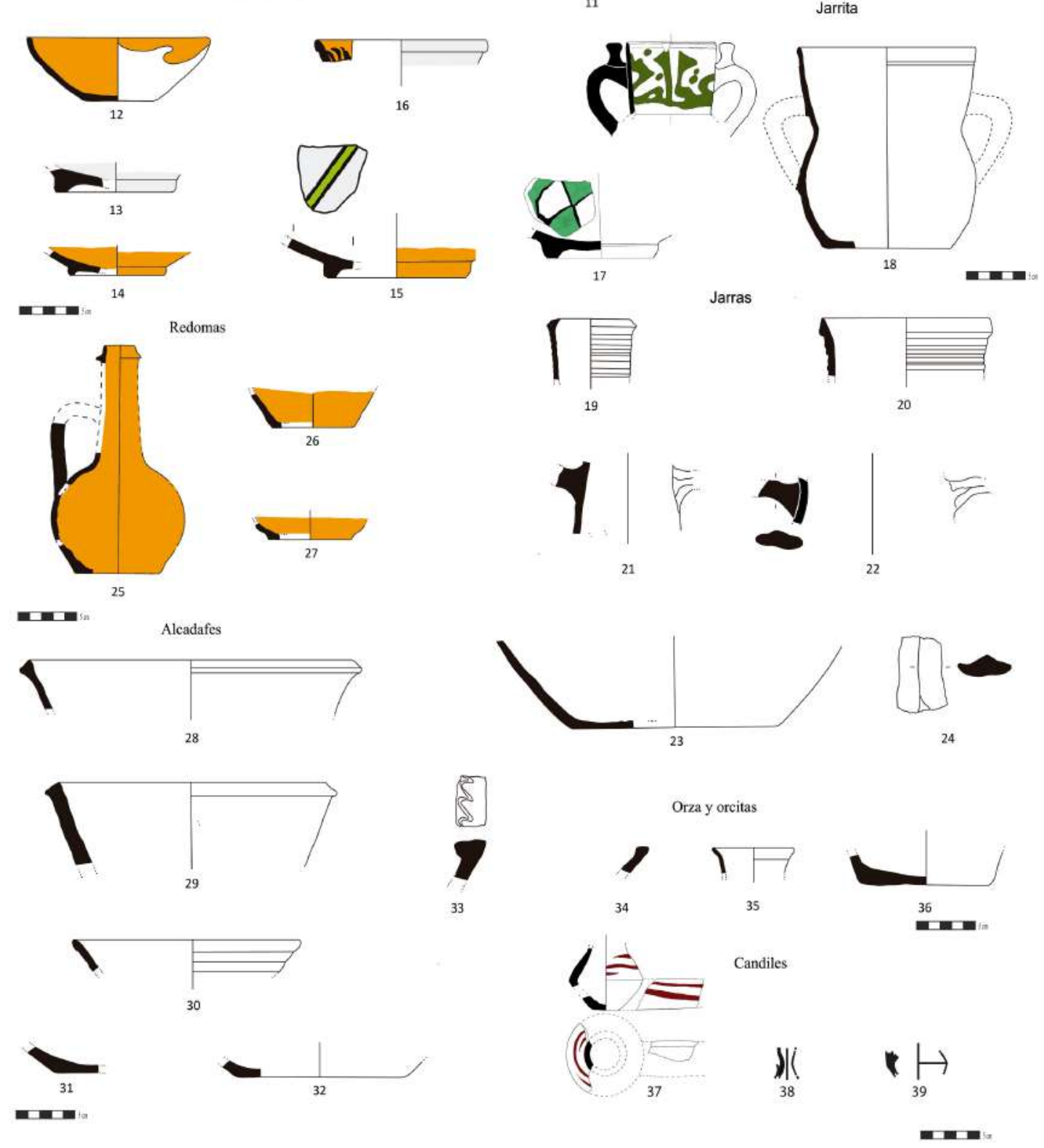

Fig. 13. Cuadro general del conjunto cerámico de la Graja. 


\subsection{Cerámica de cocina}

Entre el conjunto de materiales recuperado, el grupo más numeroso con diferencia es el de cocina (Fig. 13, $n^{0_{s}} 1-11$ ). Predominan sobre todo las ollas de tipo "valenciano", mientras que son excepcionales los restos de cazuela, así como los de marmita de base plana y paredes rectas características del área tudmirí.

Las ollas de La Graja se pueden clasificar en dos subtipos que, en realidad, constituyen variantes del mismo: en ambos casos estamos ante piezas de cuerpo globular y cuello cilíndrico, acanalado, desde el que arrancan dos asas que acaban en el hombro. Las prospecciones llevadas a cabo en el antiguo territorio castral (iqlim) de Chinchilla han permitido registrar sobradamente este tipo de ollas, de manera que constituye un auténtico fósil director para identificar unos yacimientos que generalmente apenas proporcionan materiales en superficie. El primer subtipo (Fig. 13, n $n^{\text {os }_{1}} 1-5$ ) presenta un perfil más achatado: el cuerpo de tendencia esférica y el cuello proporcionalmente más corto; parecen predominar las superficies espatuladas y las facturas a torneta. Se puede identificar con el tipo que Azuar denomina G.I (1989: 278-280), que es característico del siglo $\mathrm{XI}$. El segundo subtipo es más estilizado (Fig. $\left.13, n^{\text {os }} 6-10\right)$, de perfil acampanado, generado por la transición suave entre el cuerpo y un cuello proporcionalmente más estrecho y alto; también presenta las características acanaladuras, en este caso concentradas en la parte inferior del cuello, así como dos asas. Se halló una de estas piezas en el Bancal de las Tinajas (Bonete). Ambos subtipos convivieron en esta comarca en el mismo momento, aunque puede que el segundo sea una evolución del primero puesto que estas piezas suelen estar fabricadas a torno, lo que constituye un rasgo de modernidad, según se ha podido determinar en yacimientos estratificados.

Las ollas "valencianas" o "levantinas" fueron descritas por A. Bazzana en 1987. El primero que se aproximó al análisis de estas piezas con criterios estratigráficos de cara a determinar su evolución cronológica fue R. Azuar (1989: 278-279). Este tipo presenta una evolución formal y tecnológica, a lo largo de los siglos en que se mantiene en uso, que va desde las primeras producciones a mano de época emiral al empleo de tornos cada vez más rápidos; la incorporación de asas hacia la segunda mitad del s. X o la introducción del vidriado en el siglo XII, todo lo cual permite obtener algunas precisiones cronológicas a partir de esta serie. Serían de origen preislámico o andalusí muy temprano, de hecho, no existe constancia de este tipo de producciones en contextos árabes orientales o bereberes de los siglos VIII-IX (AMORÓS, 2020: 16-22). Parecen llegar al Valle de Alpera y Corredor de Almansa desde el área valenciana a finales del S. IX (GUTIÉRREZ, 2018: 50-55), perviven hasta el siglo XII y comienzan a desaparecer hacia época almohade de manera que, en algunos contextos concretos del primer tercio del siglo XIII, como es el arrabal del Fortí de Denia, ya no están representadas (GISBERT, BURGUERA, BOLUFER, 1995: 167).

Las excavaciones en el castillo de Oropesa han permitido afinar los criterios de datación de estas piezas; según el análisis elaborado por Negre, Lozano y Selma (2018: 242 y 243) a partir de criterios estratigráficos, algunas de las ollas de La Graja presentarían rasgos de modernidad como la factura a torno, las acanaladuras bien marcadas, la carena pronunciada entre el cuello y el hombro, y las asas verticales, junto con otros de relativa antigüedad como es la ausencia de cubierta vítrea. Por todo ello, cabría identificarlas con el tipo 4 de la serie elaborada por estos investigadores, que se fecha en el siglo XI. Efectivamente, encontramos ollas similares en contextos de dicha cronología registrados en importantes asentamientos del interior de la provincia de Alicante, como el Tossal del Moro (Benilloba), el Castillo de Cocentaina y el Sompo en el mismo municipio (RUBIO, 1989: 394, fig. 7), el Castellar de Alcoy (PÉREZ, 2014: 89-90), así como en Valencia (BAZZANA, 1987: fig. 5, n 10). También son análogas a las ollas que forman parte del conjunto hallado en Benetússer y que, a diferencia de la 
opinión de Escribà (ESCRIBÀ, BARCELÓ, 1990: 33), nosotros creemos que serían del siglo XI avanzado, a juzgar por los perfiles y pies de las formas abiertas de mesa, entre otros indicios como la morfología de los candiles o la presencia de "cuerda seca" parcial.

\subsection{Almacenamiento y transporte}

A continuación del grupo de cocina, el más representado es el destinado a la contención y servicio de líquidos, especialmente las grandes jarras para el acarreo (Fig. 13, n ${ }^{\text {os }}$ 19-24). No se ha conservado ningún ejemplar completo, aunque los fragmentos permiten identificar que se trataba de ejemplares a torno, de cuello esbelto y cuerpo globular, con asas gruesas que arrancaban cerca del borde y terminaban el hombro del vaso. Es frecuente que estos recipientes, con independencia de su cronología, presenten motivos pintados, normalmente gruesas líneas verticales; sin embargo, entre los fragmentos recuperados en la casa 16 no se ha encontrado por el momento ninguno así decorado. Dos de los fragmentos documentados permiten identificar sendas variantes que conocemos también por otros yacimientos coevos: en ambos casos se trata de cuellos acanalados; uno de ellos presenta borde recto (ESCRIBÀ, BARCELÓ, 1990: $n^{\circ} 41$ ), mientras que el segundo subtipo muestra borde exvasado (ESCRIBÀ, BARCELÓ, 1990: $n^{\circ}$ 40). Las acanaladuras del cuello emparentan a los ejemplares de La Graja con el tipo 3 de Oropesa (NEGRE, LOZANO, SELMA, 2018: 245 y 246) aunque este último ya cuenta con el característico borde escalonado que denota ser más tardío (quizás de mediados del s. XII en adelante) que los que venimos estudiando (PÉREZ, JIMÉNEZ, 2018: 173).

Se han encontrado unos pocos fragmentos de tinaja, uno de ellos con banda de refuerzo horizontal. Cabe esperar que aparezcan más restos de este tipo de recipiente que cumplía la crucial función de contenedor para almacenar el agua en la vivienda. Es posible, incluso, que se hallen más restos concentrados en alguno de los espacios de la casa que aún no han sido excavados, pues aquí debieron de ser imprescindibles ante la ausencia de pozos o aljibes domésticos. De hecho, la escasez de restos de tinajas en el ajuar que hasta ahora han proporcionado las excavaciones de La Graja parece excepcional, puesto que las prospecciones de los otros asentamientos andalusíes de la comarca han revelado la presencia de tinajas en casi todos ellos.

Las orzas (Fig. 13, ns 33 y 34) son recipientes de tamaño menor que las tinajas, carentes de cuello y destinadas normalmente al almacenamiento y conservación de alimentos; bajo esta denominación nosotros incluimos tanto a los recipientes vidriados al interior como a los que carecen de vedrío, que son precisamente los que están bien representados en el ajuar de La Graja. Se trata de recipientes de tamaño medio y cuerpo globular o piriforme, sin cuello, asas ni cubierta vítrea. Se ha podido documentar el borde de un ejemplar, con un labio muy desarrollado que se proyecta al exterior. Conserva decoración incisa cerca del borde, consistente en una sencilla banda ondulada.

\subsection{Servicio de mesa}

Destaca la presencia de fragmentos de ataifores con decoración en "verde y manganeso" y marrón sobre melado (Fig. 13, nos 12-17). Se trata de piezas de perfil curvo y unos pies anulares indudablemente más estrechos y altos que los de los ejemplares califales tardíos (JIMÉNEZ, PÉREZ, 2018: 97), pero no tanto como los de época almorávide (PÉREZ, JIMÉNEZ, 2018: 181-183); se pueden identificar con el tipo III (a) de Azuar (1989: 241 y 242), que fechó genéricamente en el siglo XI. Uno de ellos (Fig. 13, $n^{\circ}$ 16) presenta borde recto y labio redondeado y exvasado que se individualiza al exterior mediante una marcada inflexión; este rasgo formal puede ser un indicio interesante desde el punto de vista cronológico puesto que en un contexto bien estratificado como es el de la calle Pascual (Murcia) se pudo comprobar que está ausente en los ataifores de época taifa final $y$, sin embargo, se generaliza en el período almorávide inicial, hacia 1190-1110 (PÉREZ, JIMÉNEZ, 2018: láms. II.5 y 
II.6). Otro de los ejemplares corresponde a un fondo con pie relativamente alto y estrecho. Los temas decorativos son difíciles de identificar debido al estado de conservación de los restos, aunque parecen distinguirse motivos geométricos y epigráficos. Algunos fragmentos informes de ataifores y jofainas presentan decoración vidriada de ovas marrones sobre fondo melado; entre ellos, cabe destacar el hallazgo en la estancia 2 de una jofaina casi completa con cubierta vítrea melada al interior y solo goterones al exterior, que muestra el rasgo arcaizante de una base plana (Fig. 13, $\left.n^{\circ} 12\right)$. Se trata de una de las pocas series que nos permiten una aproximación cronológica, con las reservas que imponen siempre estos ensayos basados en la comparación tipológica con los materiales de otros yacimientos; en este sentido, y teniendo en cuenta todo lo expuesto, nos inclinamos por adelantar una fecha probable del último cuarto del s. XI.

Según decíamos, en La Graja se halló una jofaina (Fig. 13, n 12), es decir, una forma abierta destinada al servicio de mesa de menor tamaño que el ataifor, de perfil cóncavo, muy levemente carenado cerca del borde, cubierta vítrea melada al interior con goterones de la misma en la pared externa, y un rasgo formal que denota una antigüedad relativa como es la base plana. Se trata de una pieza bastante original para la que no encontramos paralelos claros, ni para la disposición del vedrío (normalmente estas piezas están o bien solo bizcochadas o vidriadas por ambas caras de manera uniforme), ni para la morfología; sabemos que la ausencia de pie era el rasgo dominante de los ataifores califales y que la presencia del mismo se va generalizando a lo largo del s. XI (JIMÉNEZ, PÉREZ, 2018: 97-98), pero en este caso solo podemos extrapolar alguna analogía al respecto con muchas precauciones dado que la pieza que nos ocupa no es un ataifor sino una jofaina.

Muchos de los fragmentos cerámicos, carentes de cubierta vítrea y de paredes finas, recuperados en la excavación de La Graja podrían pertenecer a recipientes para el servicio y consumo del agua, como las jarritas (Fig. 13, $n^{\circ} 18$ ); de ellas hemos podido reconstruir hasta tres ejemplares. Se trata de vasos de forma acampanada, con boca ancha y un cuello desarrollado que apenas presenta un ligero estrechamiento en el punto en donde se une al cuerpo globular; presenta una estrecha acanaladura diferenciando el borde y dos asas que arrancan de la parte inferior del cuello para finalizar en mitad de la panza. No hemos encontrado paralelos exactos de estas piezas, aunque, de manera general, podemos afirmar que la transición suave del cuello al cuerpo es un rasgo de relativa antigüedad, como se puede comprobar, por ejemplo, en la tabla cronotipológica de Azuar (1989: fig. 142), en la que se aprecia que la jarrita que formalmente más se aproxima a la nuestra es la del tipo Bbb1, fechada en el s. XI. También se han hallado varios fragmentos de jarrita con restos de pintura a la almagra; es difícil distinguir los motivos dado el mal estado de conservación de la decoración, aunque en uno de los casos, hallado sobre el suelo de la cocina de la crujía norte (estancia 3), se identifica un filete horizontal a pincel. Hay que destacar también el hallazgo, en la campaña de 2021, de una jarrita incompleta decorada con un motivo epigráfico en "cuerda seca" parcial; lo conservado es parte del cuello relativamente esbelto, así como las asas altas y rematadas por ápices.

El hecho de que no se hayan identificado jarros o jarritos hasta el momento en La Graja, parece probar que estamos alejados de los ajuares califales, en los que todavía estos recipientes para el consumo del agua eran muy frecuentes y las jarritas comenzaban a suplantarlos (JIMÉNEZ, PÉREZ, 2018: 93 y 94). Lógicamente, una observación de este tipo está sujeta a todas las cautelas, dada la información limitada de que aún disponemos en las excavaciones de La Graja, y deberá contrastarse con la que proporcionen futuras excavaciones.

Se identificaron también algunos restos de redomas (Fig. 13, nos 25-27), una de ellas casi completa, con cubierta vítrea monocroma en melado. La reconstrucción gráfica de la misma que hemos realizado es exacta excepto por lo que respecta a la altura del cuello, que hemos 
reintegrado hipotéticamente teniendo en cuenta los restos conservados y la forma de otras piezas similares en cuanto al cuerpo y al borde. En la clasificación de Rosselló esta pieza se encuadraría en el tipo I (ROSSELLÓ-BORDOY, 1975: 218), mientras que en el ensayo de sistematización cronotipológica de las redomas que elaboró Azuar (1986) se identificaría con la forma 5 , que data del siglo XI. Redomas similares están documentadas desde época califal avanzada (JIMÉNEZ, PÉREZ, 2018: fig. 16.5) hasta el siglo XII (JIMÉNEZ, NAVARRO, 1997: 44).

\subsection{Uso múltiple}

También están bien representados en La Graja los recipientes de uso múltiple o alcadafes (Fig. 13, nos 28-32); en este caso no se trata de los característicos lebrillos propios de los siglos XII y XIII sino de piezas de dimensiones más reducidas. Se distinguen dos subtipos, que comparten una serie de características comunes como son la forma troncocónica invertida, la base plana y el interior alisado; el primero, de mayor tamaño, presenta labio engrosado al exterior de sección triangular, mientras que el segundo cuenta con un borde recto y pared acanalada. En el actual estado de la investigación no se pueden llegar a precisiones cronológicas acerca de estas piezas aparte de que no tienen nada que ver con los grandes lebrillos de época almohade y que, teniendo en cuenta el resto del conjunto documentado en esta excavación, deben datarse en el siglo XI.

\subsection{Candiles}

Aunque en reducido número (Fig. 13, nos 37-39), también se documentan algunos fragmentos de candiles de piquera con un cuerpo de tipo piriforme característico del siglo XI, que se encuentra a caballo entre las cazoletas lenticulares del siglo X y las que apenas resaltan del ancho de la piquera que se generalizan en los candiles del siglo XII. Los candiles de La Graja se identifican con el tipo IV de Azuar (1989: 267 y 268), que está representado en el Castellar de Meca (BRONCANO, ALFARO, 1997: 28 y 29) y en Mompichel (RAMÍREZ, IDÁÑEZ, 1988: 77). López adscribe a la segunda mitad del siglo X el conjunto de El Castellar de Meca, Ramírez e Idáñez lo datan entre los siglos XI y XII, mientras que Azuar lo adscribe al siglo XI.

\subsection{Cronología y consideraciones generales}

El ajuar cerámico recuperado en La Graja es modesto, cuantitativa y cualitativamente: predomina la cerámica común, sobre todo ollas, y la de almacenamiento, mientras que son escasas las piezas lujosas comunes en conjuntos de la misma época, como por ejemplo las producciones de mesa vidriadas. En cualquier caso, resulta significativo de cara a situar la horquilla cronológica durante la cual pervivió el asentamiento, así como algunas otras informaciones muy valiosas, algunas de las cuales trataremos de comentar ahora.

En los apartados anteriores hemos examinado el repertorio cerámico documentado en las excavaciones de La Graja a partir de la clasificación por grupos funcionales; ahora llamaremos la atención sobre las ausencias de algunos tipos propios del repertorio de producciones cerámicas andalusíes del momento, lo que constituye otra forma de evidenciar la modestia de estos ajuares. Hay que precisar, no obstante, que la inexistencia de determinadas formas entre los materiales hallados en La Graja puede deberse, en cierto casos, a las propias limitaciones cuantitativas del registro en cuestión y a la escasa extensión de la intervención hasta la fecha, por lo que cabe esperar que aparezcan en el futuro; mientras que en otros casos, la causa de la ausencias de ciertas series es que estas aparecieron en fechas posteriores al momento de abandono de La Graja.

Entre los tipos propios de los ajuares coetáneos al de La Graja y que, consiguientemente, seguramente se hallarán en las próximas campañas, están las tapaderas planas. Sin embargo, las tapaderas cóncavas con pedúnculo se generalizaron en fechas más tardías, por lo que no es previsible que se encuentren; estas últimas sí que están documentadas 
en algunos otros yacimientos de la comarca, como el castillo de San Gregorio de Alpera, el castillo de Montealegre, Fuentechilla y Aguaza.

También cabe esperar que se encuentren los hornos portátiles o atanores que forman parte del ajuar cerámico andalusí desde época emiral y que hasta ahora no han aparecido en La Graja, aunque sí en otros yacimientos que presentan materiales análogos, como el caso de Hoya Honda. Se trata de piezas de forma troncocónica invertida, abiertas por arriba y por abajo, con bordes con labio ancho, engrosado, decorados en ocasiones con cordones digitados en la cara exterior y bandas incisas a peine en la cara interna que servían para facilitar el agarre de las tortas de pan ácimo que se adosaban a la pared interior del atanor para cocerlas. Están representados en el castillo de San Gregorio, Mompichel, Torre de Pechín, Los Villares del Bachiller y Aguaza.

Ni en La Graja ni en el resto de yacimientos se han registrado restos de arcaduces o cangilones de noria, un tipo bastante frecuente en el repertorio andalusí desde época emiral, lo que se debe con toda lógica a que estamos en un contexto claramente de secano en la mayoría de los yacimientos que venimos estudiando. Cabe la posibilidad de que en un futuro aparezcan restos de estas piezas en alguna de las alquerías que aprovechaban las escasas y reducidas vegas de la comarca, como la de Alpera, o incluso que se pueda registrar la existencia de alguna noria de "sangre" para la extracción de agua de algún pozo vinculado a estos asentamientos. Pero, en general, siempre debemos esperar que su presencia sea excepcional o, al menos, mucho más exigua que en los sitios vinculados a las huertas que proliferaron en el levante de al-Andalus.

Teniendo en cuenta que el ajuar cerámico andalusí presenta una fuerte diferenciación por regiones, los repertorios tipológicos que muestran más rasgos en común con el registro de La Graja, y en general con los yacimientos del Corredor de Almansa, son los de Denia (AZUAR, 1989; GISBERT, BURGUERA, BOLUFER, 1995) y Murcia (NAVARRO, 1986), mientras que los conjuntos ergológicos de la Meseta, especialmente del castillo de Alarcos (ZOZAYA, 1995), Calatrava la Vieja (HERVÁS, RETUERCE, 2005) y de Vascos (IZQUIERDO, 1999), parecen estar mucho más alejados de las características generales del registro documentado.

Por otro lado, es preciso tener en cuenta que seguramente también se producían localmente algunos tipos de los que componen el ajuar cerámico, al menos los más comunes que son también los más abundantes. Está bien documentada la larga tradición alfarera de Chinchilla, que aprovecha los yacimientos de arcillas de la zona, en donde consta que se fabrican lozas desde el siglo XV, entre ellas crisoles para la orfebrería (PRETEL, 1992). Las excavaciones de los caminos del Castellar de Meca (BRONCANO, ALFARO, 1997: 28 y 29) dieron como resultado la localización de unos hornos de doble cámara para la producción cerámica, que se fecharían hacia el siglo XI. Aunque no consta en la memoria que se hayan detectado evidencias que permitan determinar qué tipo de piezas se fabricaban, parece lógico suponer que se trataba de cerámica común (ollas, orza, jarras...) destinada al mercado comarcal. Hay que tener en cuenta que, a diferencia de la mayoría de las alquerías del Corredor de Almansa, que suman entre 10 y 30 casas por lo general, el despoblado andalusí del Castellar de Meca tenía la considerable extensión de 30 ha; ciertamente se trataba de un urbanismo muy disperso, pero, aun así, parece evidente que este era uno de los núcleos de población más importantes del área, si no el mayor (BRONCANO, ALFARO, 1997: 91).

Los ataifores decorados en "verde y morado" son los que nos permiten una aproximación cronológica más precisa puesto que, si el conjunto en general remite a contextos del siglo XI como el nivel de abandono de Madinnat al-Zahrā', el nivel reciente del ribāt de Guardamar (MENÉNDEZ, 2004), el Castellar de Alcoy (PÉREZ BOTí, 2014: 59-60, fig. 6) o los alfares de Elche (AZUAR, MENÉNDEZ, 1999) y de Murcia (MUÑOZ, CASTAÑO, 1993), la presencia de pies anulares relativamente altos y estrechos y 
los característicos bordes redondeados de las piezas decoradas en "verde y morado" son rasgos de relativa modernidad. Paralelos de estas piezas los encontramos en el nivel VIla de la calle Pascual (Murcia), datado en época almorávide inicial (1091-1110), en donde aparecieron las producciones de "verde y morado" más tardías de la Murcia andalusí; presentan perfil con carena suave y media, que remata en un característico borde de sección semiovalada. Aunque el tipo es frecuente en yacimientos de la Marca Central y Superior, con dataciones que pueden oscilar entre finales del siglo XI y primer cuarto del XII, creemos que cabe relacionarlo más estrechamente con el área levantina; en concreto con Valencia, en donde han aparecido piezas de este tipo que estratigráficamente parecen asociadas al importante impulso urbanístico que experimentará esa ciudad a partir de 1061 (PÉREZ, JIMÉNEZ, 2018: 177). A todo ello hay que sumar la ausencia de producciones típicamente califales como, por ejemplo, los jarros pintados, los candiles de cazoleta discoidal o los ataifores de base plana, si bien, de manera excepcional, apareció un pequeño conjunto de tres piezas en la mezquita que creemos debe fecharse en época califal. Por todo ello, en la actualidad nos inclinamos por suponer que este asentamiento surgió en la segunda mitad del siglo $X$ y fue abandonado hacia fines del siglo XI, un periodo de vida relativamente corto, unas cuatro o cinco generaciones, lo que convendría con las escasas fases constructivas que se aprecian en la estratigrafía relacionada con la arquitectura.

Como decíamos, el conjunto de cerámicas hallado en La Graja, al igual que los de las otras alquerías de la comarca, aunque estos últimos hayan sido recuperados en prospecciones, demuestran una serie de características llamativas que los distinguen de los que conocemos en otros contextos de la misma época, y no solo procedentes de ciudades sino también de husūn e incluso de alquerías. Se trata de un repertorio muy modesto en cuanto al número de ejemplares con que parecen haber contado las familias, también debido a la poca variedad del mismo, y por la escasez de piezas lujosas o al menos vidriadas o pintadas; humilde técnicamente por el alto porcentaje de recipientes hechos a mano o a torneta, e incluso por el aprovechamiento de piezas defectuosas como algunas de las ollas.

Estas características podrían poner en cuestión la hipótesis de que los habitantes de estas alquerías sean campesinos procedentes de otros puntos del Šarq al-Andalus que decidieron, o se vieron empujados a colonizar estas tierras, en principio poco apetecibles, empujados por las circunstancias socioeconómicas del momento, pues cabría suponer que habrían llevado consigo los ajuares cerámicos más refinados y variados que estaban generalizados en al-Andalus en esas fechas. Sin embargo, existen datos para pensar que estamos ante un fenómeno propio de los contextos de colonización campesina cuando esta se encuentra aún en sus fases más tempranas, como han demostrado los estudios sobre la cerámica andalusí de los primeros asentamientos islámicos en las Baleares. Estos trabajos prueban que las primeras producciones locales se realizaron a mano o a torneta, "con un repertorio bastante reducido y mayoritariamente compuesto de formas con funciones básicas, como la cocción, o con usos polivalentes, como las jarritas - en principio para el servicio de mesa - con signos de utilización para la cocción" (KIRCHNER, 2020: 488), es decir, las producciones cerámicas de los campesinos šarquíes que colonizaron las islas a partir del $\mathrm{s}$. X eran, durante los primeros tiempos, mucho más modestas que las que en ese momento eran de uso común en el continente del que procedían: "La explicación no puede ser otra que el hecho de que en el siglo X, cuando se produce la migración, los grupos que se asientan en las islas no encuentran una infraestructura artesanal y comercial organizada. Y ellos no la organizan de forma inmediata. Lo que sí tuvo que organizarse de forma inmediata era la selección de lugares donde crear espacios de cultivo y pasto para garantizar la sobrevivencia de los pioneros. Solo cuando esta infraestructura estuvo consolidada, los grupos asentados pudieron empezar 
a destinar gente a otros menesteres distintos a los de la producción de alimentos: la fabricación especializada de objetos y herramientas. En el siglo XI, o quizás ya desde finales del X, las producciones locales de cerámica se realizan a torno, con vidriados, decoraciones complejas y repertorios diversificados. Son producciones realizadas por talleres de especialistas y comercializadas en los mercados rurales y urbanos" (KIRCHNER, 2020: 488).

A diferencia de lo que sucedió en las Baleares, el poblamiento de La Mancha oriental que venimos estudiando colapsó a partir de fines del siglo XI, cuando se abandonó la mayoría de los núcleos de población que había hasta entonces y cuya existencia no se había extendido más allá de pocas generaciones, por lo que no pudieron evolucionar hasta alcanzar el nivel de desarrollo que Kirchner describe para los asentamientos isleños. Es posible que los núcleos de población que pervivieron a la crisis y que concentraron en gran medida a los labradores de las alquerías abandonadas (Almansa, Chinchilla, seguramente Higueruela, Carcelén...) sí que registraran ese crecimiento y especialización manufacturera, aunque actualmente la arqueología y los documentos apenas aportan datos al respecto con la excepción de algunas informaciones relativas a Chinchilla.

\section{METALES Y HUESOS}

El conjunto de metales obtenidos de la intervención es muy reducido, pero también interesante porque permite documentar algunos aspectos singulares de las actividades domésticas de estas familias campesinas. Todas las herramientas han sido localizadas sobre los pavimentos, como resultado del abandono debido en casi todos los casos a su desgaste o rotura. El conjunto lo podemos dividir en dos grupos según se trate de objetos fundidos en bronce o fabricados en hierro.

Solo se encontró un instrumento de aleación de cobre; apareció en la estancia más pequeña, la número 5 , concretamente junto al muro que la delimita por el sur. Se trata de una aguja completa bi-apuntada de sección circular, con claros indicios de desgaste en los extremos ocasionado por su uso frecuente (Fig. 14, $\mathrm{n}^{\circ}$ 1). A falta de los pertinentes análisis metalográficos que determinen la calidad de la aleación o la presencia de zinc que lo aproxime a los latones, es posible que el objeto se emplease en tareas relacionadas con el trabajo textil.

Uno de los instrumentos de hierro que se ha recuperado es un cuchillo de escasa longitud que conserva su vástago rectangular y una pequeña hoja de punta redondeada; por sus dimensiones debe de relacionarse con las

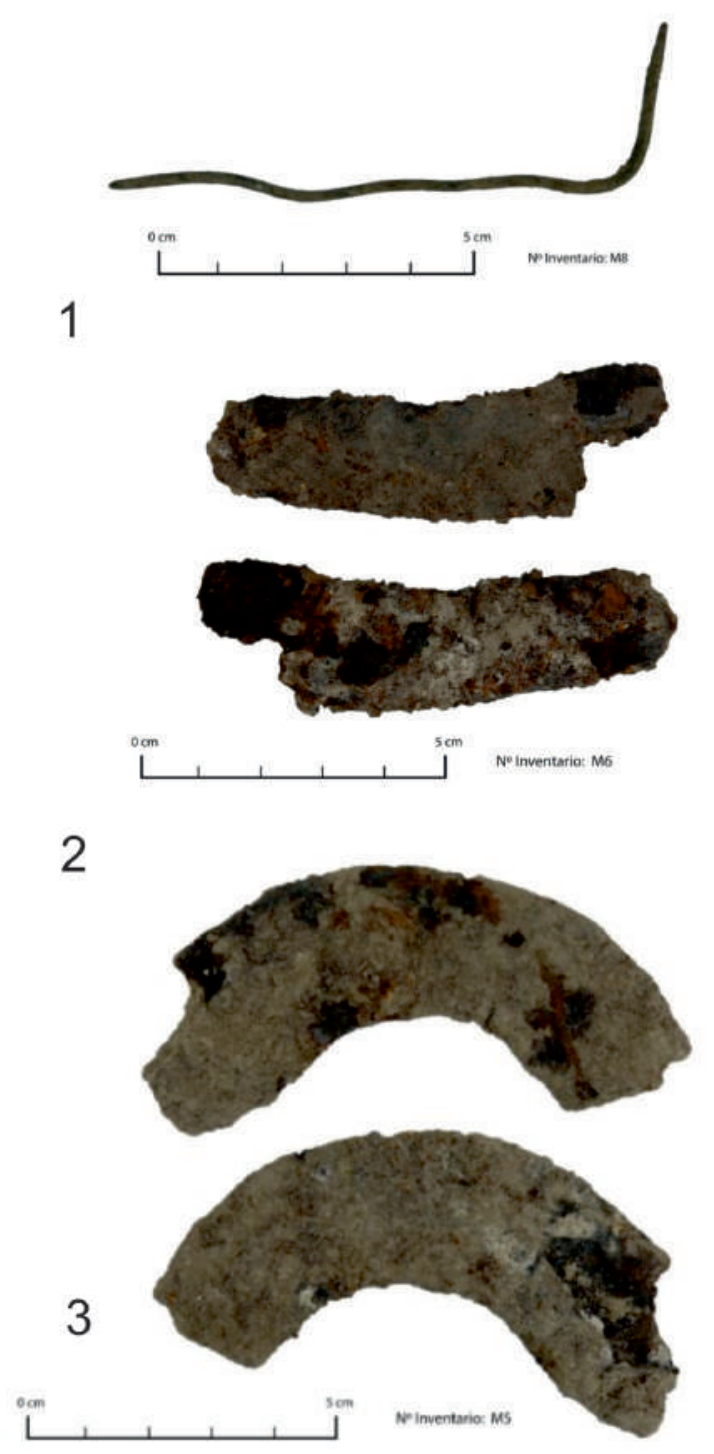

Fig. 14. Objetos metálicos hallados en la casa 16. 
tareas domésticas y, de hecho, apareció junto al hogar de la estancia 3 (Fig. 14, n²).

En la estancia 2, junto al hogar, se encontró parte de una herradura de arco reducido (Fig. $\left.14, n^{\circ} 3\right)$, por lo que podría ser de un équido de pequeño tamaño, como un burro o un asno; su presencia demuestra la existencia de caballerías que pudieron emplearse para el transporte y para diferentes labores agrícolas, como el arado o la trilla. También debe de asociarse con el atalaje de las caballerías un pasador de hierro en forma de ocho, característico de las funciones de sujeción y ajuste de correajes, que se localizó en los niveles de derrumbe de la estancia 2.

Finalmente, en la estancia 3 se hallaron un clavo y una alcayata, objetos de función evidente, aunque no sabemos a qué uso en concreto podemos asociarlos.

Todo el conjunto responde a los parámetros habituales de los objetos metálicos propios de comunidades campesinas, con las tipologías y formas propias del contexto cronocultural andalusí al que corresponden.

La escasa presencia de restos de fauna en el interior de las estancias hay que ponerla en relación con el tipo de abandono del yacimiento, que al parecer se produjo de manera simultánea en toda la alquería, de manera que no hubo espacios domésticos abandonados que se emplearan como vertedero por parte de población residual. En consecuencia, creemos que será en el patio en donde puede que existan más residuos de la vida cotidiana de los moradores de la casa, así como en posibles basureros o vertederos en el exterior de las viviendas. No obstante, en la estancia 5 apareció un fragmento distal de un metatarso de bóvido que, a falta del estudio zooarqueológico, apunta a la presencia de estos animales entre la cabaña ganadera del grupo humano de la alquería, bien como animal de tiro, para el consumo de su carne y productos secundarios o, incluso, para todos esos fines.
En cuanto a los hallazgos malacológicos solo cabe señalar la presencia de caracoles de variedades locales.

\section{DISCUSIÓN}

El análisis de la estratigrafía y de la cerámica asociada a la casa 16 ha proporcionado información muy relevante acerca de la cronología del yacimiento y, en consecuencia, de su historia. En nuestro estudio publicado en 2017 afirmamos, en relación con la cronología de estas alquerías del Corredor de Almansa, que para fecharlas "no contamos con información alguna procedente de las fuentes escritas ni de secuencias estratigráficas, pues en ninguna de ellas se han practicado excavaciones arqueológicas. [...] los datos más fiables proceden de las cerámicas recuperadas en superficie durante las prospecciones sistemáticas" (JIMÉNEZ, SIMÓN, 2017: 241). Lo que nos llevaba a concluir que "Gracias a los hallazgos muebles, especialmente a la cerámica, parece posible suponer, a falta de excavaciones arqueológicas, que estos asentamientos surgieron hacia la primera mitad del siglo XI y fueron, en general, abandonados con motivo de la conquista en el segundo tercio del siglo XIII" (JIMÉNEZ, SIMÓN, 2017: 245). En la actualidad, una vez que hemos podido extender el estudio de los materiales procedentes de prospecciones a un número mucho más significativo de alquerías y que hemos podido llevar a cabo excavaciones en La Graja, creemos que dicha afirmación debe ser matizada, pues si bien mantenemos el siglo XI como fecha en la que se originaron estos asentamientos, nos inclinamos por pensar que buena parte de ellos se abandonó a finales del siglo XI y solo algunos llegaron al siglo XIII o a fechas posteriores, por lo que La Graja no sería un caso aislado sino que ilustraría un proceso histórico relativo al poblamiento andalusí del área sudoriental de La Mancha (Fig. 1). En La Graja, esa cronología está avalada por los materiales correspondientes a la fase final del yacimiento, hallados sobre los suelos, tal y 
como hemos descrito, mientras que en el resto de las alquerías la prueba sería la ausencia de cerámicas más tardías entre las recuperadas en superficie.

Los yacimientos que parecen presentar un registro cerámico análogo al de La Graja son alquerías que oscilan entre las 10 y 20 viviendas similares a la casa 16 en cuanto a aparejo constructivo y disposición de la planta en términos generales. La mayoría de ellas, aunque no todas, están situadas en llano, en contextos geográficos similares al de La Graja; dos se emplazan incluso en el mismo valle: se trata de Malefatón y Tobillos, ambas en Alpera; a estas hay que sumar Las Peñicas o Malas Tardes (Chinchilla), La Carrasquilla (Corral-Rubio), San Antón (Albacete), Hoya Honda (Higueruela), La Toyosa (Chinchilla) y Los Castillicos o La Rambla, esta última también en el secano de Higueruela aunque en este caso situada en altura. Incluso es probable que se pueda incluir en este grupo al gran asentamiento del Castellar de Meca. Existe también un grupo más reducido de yacimientos que también parecen surgir (o al menos experimentar un despegue significativo) al mismo tiempo que las alquerías mencionadas, pero estos no desaparecen a fines del s. XI sino que perviven hasta la conquista cristiana; se trata de las alquerías del Villar del Bachiller (Chinchilla), Aguaza, Torre de Bogarra y, sobre todo, estaciones con valor defensivo por la orografía, como Mompichel, el castillo de San Gregorio (Alpera), la torre de Pechín e, incluso, los asentamientos andalusíes que precedieron a las actuales Almansa, Montealegre e Higueruela.

El poblamiento y colonización durante este periodo de tierras desfavorecidas, como las de La Mancha oriental, ha de enmarcarse en un contexto de expansión comercial y agraria, seguramente enraizada en el despegue demográfico. El aumento de la demanda de alimentos incrementó la rentabilidad comercial de la agricultura y ello comportó la presión de las oligarquías urbanas para hacerse con la tierra, arrebatándosela, en algunos casos, a las comunidades campesinas de las alquerías, como relata Ibn Hayyān, o estableciéndose en áreas menos favorables pero deshabitadas, como sucede con las almunias del Pla de Lérida o los rahales del campo murciano. Según creemos, la colonización de espacios que hasta entonces habían permanecido desocupados por su escasa rentabilidad no solo fue labor de las elites terratenientes con fines comerciales, sino que también la llevaron a cabo, y seguramente en mayor medida, comunidades campesinas independientes cuya actividad estaba orientada fundamentalmente al autoabastecimiento y su propia supervivencia, y no al mercado. Esto no significa que prescindieran de las relaciones comerciales, pues el establecimiento de formas de intercambio, no solo con los centros urbanos sino también con otras alquerías, era fundamental para estos grupos como estrategia de producción y de abastecimiento que garantizara su perduración.

Los ejemplos que dan testimonio de esta colonización campesina del secano serían precisamente los asentamientos rurales que venimos estudiando en La Mancha oriental y otros que se vienen documentando durante los últimos tiempos en zonas igualmente desfavorecidas, como el sur de la provincia de Teruel, en donde se ha localizado un centenar largo de asentamientos menores junto con unas pocas alquerías de mayor tamaño que pudieron rondar el centenar y medio de habitantes, cuyo origen se sitúa avanzada la etapa califal a tenor de los lotes cerámicos recuperados (ORTEGA, VILLARGORDO, 2020: 179-181). De la misma manera, también en el sector central de La Mancha se ha comprobado la consolidación de comunidades campesinas asentadas en alquerías "localizadas a lo largo del Cigüela, a partir del siglo X, alcanzando su auge en la centuria siquiente, sobre todo durante el gobierno de la taifa toledana" (MALALANA, MORÍN, 2013:2021); se trata de establecimientos en llano de carácter agropecuario, que contaban con norias de sangre que habrían permitido desarrollar una agricultura mixta de secano y regadío, compaginada con ganadería trashumante y estante. El registro de fenómenos similares en áreas distantes del suroeste de al-Andalus, como sucede en Alcaria Longa (Mértola, Portugal) en donde las excavaciones han revelado 
un asentamiento rural ocupado durante un periodo de tiempo relativamente corto, entre los últimos años del siglo X o primeros del XI y fines de época taifa, llegando quizás a comienzos del periodo almorávide (BOONE, 1992: 63; 1993: 112), parece probar que efectivamente estamos ante un proceso general de amplio alcance y no ante una coyuntura local.

A pesar de estar distribuidas por una comarca poco favorable para el desarrollo agrícola, las alquerías del Corredor de Almansa no estaban aisladas de las redes de comercio regionales: su ubicación junto a vías pecuarias y la presencia del patio-corral permite acreditar la importancia que tenía la actividad ganadera en su economía, seguramente destinada a la producción de lana para los talleres textiles de medinas más o menos próximas como Chinchilla, en donde está acreditado el auge de estas manufacturas. Además, el emplazamiento de La Graja frente a una fértil depresión, la existencia de silos y el hallazgo, en la casa 16, de pruebas que evidencian la existencia de animales de tiro (una herradura y restos óseos de bóvidos), demuestran que la agricultura de secano también debió de ser un recurso fundamental para estos campesinos, quizás más orientada al autoconsumo mientras que la ganadería permitiría generar excedentes comercializables en carne y lana. Precisamente, el hallazgo de algunas cerámicas decoradas en "verde y morado", así como otras vidriadas como jofainas y redomas, demuestra que los habitantes de la alquería tenían la posibilidad de adquirir algunos bienes elaborados en los centros urbanos y que debió de existir un cierto intercambio comercial con los mismos, especialmente con los del área valenciana según parece indicar el tipo de vajilla de cocina empleado. No obstante, la capacidad de adquirir productos de lujo por parte de los habitantes de La Graja era limitada a juzgar por lo escaso de estos hallazgos, especialmente si los comparamos con los de otras alquerías de similar cronología y contexto geográfico muy parecido, como la de El Quemao, en donde se ha encontrado un volumen importante de cerámica en "verde y manganeso", cuentas de collar, aplicadores de kohol e incluso objetos distinguidos, como los fragmentos de una arqueta de hueso decorada con motivos epigráficos y zoomorfos tallados.

El registro arqueológico de la casa 16 de La Graja acredita su carácter decididamente rural, lo que seguramente se puede extrapolar al resto de viviendas de este asentamiento e incluso de las otras alquerías de la región que conocemos gracias a las prospecciones, a juzgar por las similitudes que se deducen de la observación de los restos superficiales. En primer lugar, los materiales empleados, fundamentalmente mampostería y tierra, se pueden obtener a pie del yacimiento, al igual que debió de suceder con los rollizos de madera y ramas de las techumbres. Por el contrario, están ausentes los materiales que requieren artesanos especializados en su preparación: los ladrillos eran inexistentes; apenas se utilizó la cal y el yeso, y los fragmentos de teja hallados son escasos, aunque en este caso creemos que en gran medida pudieran ser reaprovechadas tras el abandono de la vivienda.

En segundo lugar, el carácter rural de esta arquitectura se manifiesta en la planta de las viviendas, con patios proporcionalmente muy extensos y carentes de espacios domésticos especializados como letrinas, alcobas y salones. Cabe recordar en este sentido que, incluso en alquerías de la misma época, como la de El Quemao, las viviendas disponen de salones oblongos con alcobas en los extremos, enlucidos de yeso e, incluso, zócalos pintados (ORTEGA, VILLARGORDO, 2020: 177). Estos salones característicos de la arquitectura residencial andalusí, piezas multifuncionales en donde se desarrolla la mayor parte de la vida doméstica y que sirven también de espacio de recepción para las visitas, son la habitación más destacada de la casa y como tal se suelen ubicar en la crujía norte, la que disfruta de la orientación privilegiada del mediodía. En la casa 16, sin embargo, esta crujía no está ocupada por una sola pieza sino por dos, separadas por un muro que se sitúa en el eje del patio, en donde normalmente se emplazaría la puerta de acceso al mencionado salón. De esta manera, el salón, con una alhanía en su extremo, queda situado en la habitación más 
occidental de dicha crujía, mientras que en la oriental se sitúa la cocina; es decir, la orientación privilegiada se comparte entre el salón y una pieza tan funcional como la cocina, de modo que incluso la puerta de acceso al salón queda muy desplazada del eje del patio, casi esquinada, lo que demuestra el carácter extremadamente práctico de la arquitectura doméstica de la alquería de La Graja, en donde apenas se aprecian concesiones a lo suntuario. Por otra parte, la presencia de la letrina es propia de la arquitectura residencial de las ciudades andalusíes; incluso de los asentamientos campesinos cuando presentan un desarrollo urbano incipiente, como es el caso por ejemplo de la Villa Vieja de Calasparra, de manera que su ausencia ha de interpretarse como prueba del carácter intensamente rural de la alquería que nos ocupa (REKLAITYTE, 2005: 211).

Si bien nuestra investigación aún se encuentra en un estado inicial, el registro arqueológico de las prospecciones y las excavaciones no permite apreciar hasta ahora, ni en el ajuar mueble ni en la arquitectura, "estrategias de distinción" comparables a las del mundo urbano como acontece en El Quemao, asentamiento coetáneo de La Graja que presenta muchas analogías en cuanto a las características del medio rural en el que se inscribe, pero también importantes diferencias en el registro arqueológico que demuestran que los campesinos de uno y otro no compartían mismo estamento social. O dicho de otra manera, la comparación entre ambas alquerías del secano andalusí de mediados del siglo XI demuestra que existían diferencias económicas y sociales entre los campesinos de ambas; de manera que, mientras que los de la turolense tenían acceso a bienes manufacturados similares a los que disfrutaban las élites, y moraban en casas de tipología urbana, los de la albaceteña habitaban viviendas plenamente rurales. Las razones que explican estas desigualdades las desconocemos y forman parte de las incógnitas que habrá que despejar en futuros estudios; no obstante, quizás ya contemos con algún indicio: en El Quemao apareció una pesa pequeña de unas 4 onzas (ORTEGA, VILLARGORDO, 2020: 190 y 191), propia de una balanza de cierta precisión, lo que debemos poner en relación con el pesaje de productos muy valiosos, con toda probabilidad el oro y la plata de las transacciones mercantiles (ABATTOUY, 2004: 121), lo que demuestra que los campesinos de la alquería turolenses comercializaban sus excedentes de la misma manera que lo hacía el rico propietario de la almunia de Liétor (NAVARRO, ROBLES, 1996), en donde también aparecieron varias balanzas de este tipo. Por el contrario, ni el ajuar cerámico ni el registro arqueológico en general han probado, por el momento, que los habitantes de La Graja alcanzaran tal desarrollo en su relación con el mercado.

En cuanto a las circunstancias del abandono de La Graja, además de la información proporcionada por la cerámica existen otros indicios aportados por la excavación arqueológica. Las evidencias demuestran que la despoblación de la alquería fue relativamente tranquila, pues no se han encontrado rastros de destrucción violenta (incendios, ajuares domésticos abandonados). Por el contrario, apenas se dejaron piezas completas, mientras que algún vano, como el de la estancia 5, fue tapiado a la espera de evitar la ruina del edificio. Existe otro dato significativo: los rollizos y vigas de las techumbres, así como las tejas, parecen haber sido retirados para ser reutilizados, según se infiere de los escasos fragmentos de teja hallados y del hundimiento de los muros hacia el interior de las estancias, prueba de que cuando se produjo la ruina de las obras, las vigas, que habrían generado empujes hacia el exterior, ya habían desaparecido. Por otra parte, las evidencias acerca del reaprovechamiento de materiales constructivos probarían que los habitantes de la alquería de La Graja, o al menos una parte de ellos, no emigraron a puntos lejanos de al-Andalus, puesto que en ese caso no habría compensado el coste del transporte de materiales relativamente poco valiosos como los rollizos de madera y las tejas; por el contrario, debieron de trasladarse a emplazamientos próximos, de manera que fue posible y rentable reutilizar esos elementos constructivos. Creemos que este fenómeno no aconteció de manera excepcional 
en la alquería excavada, sino que se pudo dar de manera generalizada en los asentamientos de la comarca que hemos prospectado y que muestran un registro material en superficie similar al de La Graja, aunque solo mediante futuras intervenciones arqueológicas podrá confirmarse esta hipótesis.

Recapitulando, los indicios arqueológicos comentados, así como la información que se deriva del estudio cerámico de La Graja y de las prospecciones de los yacimientos de la región apuntan a un abandono generalizado, hacia fines del siglo XI, de estas alquerías vinculadas fundamentalmente a la explotación de los recursos agropecuarios del secano y situadas mayoritariamente en llano y sin elementos defensivos construidos. Se trata de la misma fecha en que se abandonan los asentamientos de Gúdar-Javalambre (Teruel) y también, aproximadamente, los del valle del Salado (Guadalajara); en este último caso el fenómeno sería algo más temprano, aunque es necesario tener en cuenta que estamos en una comarca más septentrional que las anteriores y que fue conquistada por los castellanos ya a fines del siglo XI: "parece haber un momento en el que proliferan estos yacimientos en el siglo X, para en el siglo XI reducirse en número, abandonándose algunos, y concentrándose el hábitat en los asentamientos en altura. Obviamente, habría que relacionar este hecho con el avance castellano y la conquista de la parte norte del valle, en torno a Atienza y su tierra" (GARCÍA-CONTRERAS, 2017: 125). La unión de los grupos dispersos de campesinos les proporcionaba una mayor seguridad, incluso si los sitios en que se aglutinaban no presentaban mejores condiciones naturales para su defensa que las alquerías previas; esta podría ser la razón del fenómeno que se ha registrado también en Jolopos (Granada): "Au cours de la période des taifas, en tout état de cause, l'habitat a totalement changé d'organisation, et se présente maintenant étroitement regroupé, en diverses alquerías d'organisation compacte, comme celle de Jolopos, installée en contrebas de l'ancien hisn émiral, celles de Syllar, Diezma et peut-être Darro" (BERTRAND, SÁNCHEZ, 2002: 148). De igual manera, las alquerías vecinas de Foietes y de
Tossal-l'Alfarella (Alicante) convivieron, al parecer, hasta finales del siglo XI, lo que explicaría la existencia de una mezquita rural a medio camino de ambas, por lo que el abandono de la primera y la permanencia de la segunda podría obedecer a este mismo fenómeno. Todos estos ejemplos ilustran un proceso histórico que tuvo lugar en un momento determinado y en unos contextos socioeconómicos análogos al del sector oriental de La Mancha, en donde también parece que eventualmente la población se pudo concentrar en algunos asentamientos que efectivamente pervivieron, como el Villar del Bachiller, Aguaza o la Torre de Bogarra; ignoramos las razones que motivaron la elección de estos lugares y la despoblación de los otros, aunque conviene destacar que la alquería del Bachiller, que alcanzó la extensión de 6 ha, se situaba en medio de las tierras más fértiles de la comarca.

Además de este proceso puntual de concentración en algunos sitios del llano (Fig. 1), parece que lo que ocurrió de forma más generalizada en el territorio que venimos estudiando fue el desplazamiento de la población hacia asentamientos mejor protegidos por la orografía, como los hușūn de San Gregorio de Alpera, Almansa, Caudete, Chinchilla 0 la misma Higueruela, todos los cuales parecen haber surgido en torno al año 1000 o, al menos, haber experimentado un considerable desarrollo demográfico en ese momento, quizás coincidiendo primero con la colonización extensiva de esta comarca a fines del s. $X$ y, posteriormente, con el abandono generalizado de las alquerías del llano un siglo después y su agrupamiento en esos núcleos. La causa de dicha concentración del poblamiento, sobre todo en los lugares mejor defendidos, solo puede ser el incremento de la inseguridad.

Parece lógico suponer que la ausencia de las mínimas condiciones defensivas de aquellos enclaves del llano, en un momento en que la conquista de Toledo por los castellanos (1085) creó una grave situación de inestabilidad al sur del Tajo, como prueban las correrías del Cid y del propio Alfonso VI por el sureste y el establecimiento de una auténtica cabeza 
de puente castellano-leonesa en Aledo (10861092), debieron de empujar a la población de la zona a concentrarse en emplazamientos cuyas características los hacían más adecuados para su protección. Una prueba indirecta de que, efectivamente, la razón de esta transformación del modelo del poblamiento obedeció a causas externas y no a dinámicas relacionadas con la evolución de la propia sociedad andalusí sería el hecho de que este fenómeno no se dio en aquellas regiones de al-Andalus que no estuvieron expuestas al avance conquistador castellano-leonés de fines del siglo XI, como sucedió con las islas Baleares en donde, según Kirchner, "las cerámicas halladas en los yacimientos arqueológicos indican que hubo un abandono en el momento de la conquista feudal a principios del siglo XIII. Salvo alguna excepción, la falta de abandonos anteriores a esta fecha permite pensar que no existió un porcentaje elevado de asentamientos iniciales fracasados" (KIRCHNER, 2020: 487); conviene recordar que, al igual que las que nos ocupan, la mayoría de estas alquerías isleñas presentan materiales que datan al menos desde principios del siglo XI y, en algunos casos de Ibiza, del siglo X. En similares condiciones socioeconómicas, el factor que explicaría el abandono de las alquerías de Guadalajara, Teruel y La Mancha, y que no se dio en las Baleares, sería el incremento de la presión cristiana sobre las tierras islámicas del continente.

En fin, a pesar de trabajar con una documentación escrita tan escueta, la información siempre parcial de las prospecciones y unas excavaciones arqueológicas que ahora están en sus inicios, creemos que los argumentos expuestos son suficientes para demostrar el interés que presenta el estudio de estos yacimientos de La Mancha oriental, y de La Graja en concreto, para el conocimiento histórico, no solo de la región, sino de al-Andalus en general. No son muchas las certezas con que ya contamos, pero estas son profundamente innovadoras pues nos han mostrado algunos aspectos de la sociedad y la economía andalusí cuyo estudio no había sido desarrollado o que simplemente se ignoraban, como la extensión de la colonización de las tierras del secano y la imbricación de este fenómeno con un proceso general de expansión económica en el siglo XI que presenta más rasgos en común con lo que aconteció en el resto de Europa de lo que hasta ahora se sospechaba. También nos permiten comenzar a examinar los aspectos particulares que los diferenciaban, como las pautas de la ocupación y creación de propiedad de la tierra en al-Andalus, que nada tienen que ver con las señoriales; así como las circunstancias relacionadas con la presión militar de los reinos cristianos que provocaron la crisis y transformación radical del modelo de poblamiento. Pero más allá de los datos positivos que hemos expuesto en las páginas anteriores, nos ha interesado dejar planteados una serie de interrogantes e hipótesis, que creemos necesario presentar para su análisis y crítica con el fin de optimizar el rendimiento científico de las futuras investigaciones arqueológicas sobre estos yacimientos.

\section{BIBLIOGRAFÍA}

ABATTOUY, Mohamed (2004): "Science des poids et hisba: Prolégomènes à l'étude des structures sociales de la mécanique arabe médiévale", en B. El Bouzzati (coord.), Les éléments paradigmatiques, thématiques et stylistiques dans la pensée scientifique, pp. 119-130. Rabat: Publications de la Faculté des Lettres.

AL-IDRĪSİ (1968): Nuzhat al muštaq. Edición y traducción francesas parciales de R. Dozy, M. J. de Goeje, Description de l'Afrique et de l'Espagne. Leiden: Brill.

AMORÓS, Victoria (2020): "Entre ollas y marmitas. Una reflexión sobre la producción cerámica entre los siglos VII y IX en el sureste de la península Ibérica", Arqueología y Territorio Medieval, 27, pp. 11-36. https://doi.org/10.17561/aytm.v27.5258

AZUAR RUIZ, Rafael (1986): "Apunte para un ensayo de evolución crono-tipológica de la redoma hispano-musulmana”, en J. Zozaya (coord.), Actas del Segundo Coloquio Internacional de Cerámica Medieval en el Mediterráneo Occidental. Madrid, 1986, pp. 185-187.

AZUAR RUIZ, Rafael (1989): Denia islámica. Arqueología y poblamiento. Alicante: Diputación Provincial de Alicante, Instituto Alicantino de Cultura Juan Gil-Albert.

AZUAR RUIZ, Rafael; MENÉNDEZ FUEYO, José L. (1999): "El alfar islámico de Elche (Alicante) (siglos XI-XIII)", en P. B. Ramírez y R. Balbín Berhrmann (coords.), I/ Congreso de Arqueología Peninsular, vol. 4, pp. 679-691. Zamora: Fundación Rei Afonso Henriques.

BARCELÓ, Miquel; KIRCHNER, Helena; LLURÓ, Josep; MARTÍ, Ramón; TORRES, José (1988): Arqueología medieval. En las afueras del "medievalismo. Barcelona: Crítica, D. L. 
BAZZANA, André (1987): "Essai de typologie des ollas valenciennes", en J. Zozaya (coord.), Segundo Coloquio Internacional de Cerámica Medieval en el Mediterráneo Occidental, pp. 93-98. Madrid: Ministerio de Cultura, Subdirección General de Arqueología y Etnología.

BAZZANA, André (1992): Maisons d'al Andalus. Habitat Médiéval et Structures du peuplement dans l'Espagne orientale, 2 vols. Madrid: Collection de la Casa de Velázquez.

BAZZANA, André; CRESSIER, Patrice; GUICHARD, Pierre (1988): Les châteaux ruraux d'al-Andalus. Histoire et archéologie des husûn du sud-est de l'Espagne. Madrid: Collection de la Casa de Velázquez.

BERTRAND, Maryelle et alii, (1990): "La vivienda rural medieval de E Castillejo (Los Guájares, Granada)", en J. Bermúdez Lópezy A. Bazzana (coords.), La casa hispano-musulmana. Aportaciones de la arqueología, pp. 207-227. Granada: Patronato de la Alhambra y Generalife.

BERTRAND, Maryelle; SÁNCHEZ, José Ramón (2002): "Jolopos (La Peza, Grenade). Un hișn de la fitna", en I. C. Ferreira Fernandes (coord.), Mil Anos de Fortificaçoes na Península Ibérica e no Magreb (500-1500): Simpósio Internacional sobre Castelos (2000. Palmela), pp. 145-160. Lisboa: Colibri.

BOONE, James L. (1992): "The first two seasons of excavations at Alcaria Longa: a Caliphal-Taifal period rural settlement in the lower Alentejo of Portugal", Arqueologia Medieval, 1, pp. 51-64.

BOONE, James L. (1993): "The third season of excavations at Alcaria Longa”, Arqueologia Medieval, 2, pp. 111-126.

BO0NE, James L. (2009): Lost Civilization. The Contested Islamic Past in Spain and Portugal (Duckworth Debates in Archaeology). Londres: Gerald Duckworth \& Co.

BRONCANO, Santiago; ALFARO, María del Mar (1997): Los accesos a la ciudad ibérica de Meca mediante sus caminos de ruedas. Valencia: Diputación de Valencia.

BRUFAL, Jesús (2009): "La Lleida de secano en los siglos XI-XIII: nueva interpretación del territorio", en A. Malpica (ed.), Análisis de los paisajes históricos. De al-Andalus a la sociedad feudal, pp. 241265. Granada: Alhulia.

CARA BARRIONUEVO, Lorenzo (2009): "Huellas de pastores: observando los paisajes ganaderos de los "extremos» granadinos", en A. Malpica (ed.), Análisis de Los Paisajes Históricos. De Al-Ándalus a La Sociedad Feudal, pp. 169-202. Granada: Alhulia.

CARRILERO MARTíNEZ, Ramón; GARCÍA MORATALLA, Pedro Joaquín; CIFO GONZÁLEZ, Manuel; VALDELVIRA GONZÁLEZ, Gregorio (2014): Pueblos de la provincia de Albacete en las Relaciones Topográficas de Felipe II (Estudio documental, filológico e histórico), Albacete: Instituto de Estudios Albacetense "Don Juan Manuel".

CARVALHO DOS SANTOS, Filipe J. (2006): "O povoado islâmico dos Alcariais de Odeleite. Uma qarya no Algarve Oriental. Primeiros resultados arqueológicos", Promontoria, 4, pp. 161-265.

CHAVARRÍA VARGAS, Juan Antonio (2011): Cuando Castilla-La Mancha era Al-Andalus: geografía y toponimia. Ciudad Real: Almud, Ediciones de Castilla la Mancha.

CRESSIER, Patrice (1984): "Las fortalezas musulmanas de la Alpujarra (Provincias de Granada y Almería) y la división político-administrativa de la Andalucía oriental", Arqueología espacial. Coloquio sobre distribución y relaciones entre los asentamientos, 5. Época romana y medieval, pp. 179-199. Teruel: Diputación de Aragón.

EIROA RODRÍGUEZ, Jorge Alejandro (2012): "Past and present of the Archaeology of the alquerías", Imago temporis. Medium Aevum, 6, pp. 386-406.

ESCRIBÀ, Felisa; BARCELÓ, Carmen (1990): La cerámica califal de Benetússer. Madrid: Ministerio de Cultura, Dirección General de Bellas Artes y Archivos.

ESQUEMBRE BEBIA, Marco Aurelio; ORTEGA PÉREZ, José Ramón; MOLINA MAS, Francisco; MOLINA-BURGUERA, Guillermo (2003): "Vivienda y trama urbana de época Islámica en el sur de Alicante", en F. J. Jover Maestre y C. Navarro Poveda (coords.), De la medina a la Vila. II Jornadas de Arqueología Medieval, pp. 59-81. Petrer-Novelda: MARQ-CEL.

GARCÍA-CONTRERAS RUIZ, Guillermo (2017): "Algunas cuestiones para el debate sobre los asentamientos rurales: protocolo de estudio del valle del Salado (Guadalajara) entre los siglos Xy XII", Debates de Arqueología Medieval, 7, pp. 97-146.

GARCÍA-SAÚCO BELÉNDEZ, Luis; SANTAMARÍA CONDE, Alfonso (1986): "Unos baños árabes en Chinchilla", en R. Sanz Gamo (ed.), Congreso de Historia de Albacete, Vol. I, pp. 389-397. Albacete: Instituto de Estudios Albacetenses "Don Juan Manuel".

GARCÍA GANDÍA, José Ramón; LLORENS CAMPELLO, Sonia; PÉREZ BOTÍ, Germán (2004): "L’Almisserà: territorio castral y espacio rural en época islámica", en F. J. Jover Maestre y C. Navarro Poveda (eds.), De la medina a la vila. II Jornadas de Arqueología Medieval, pp. 83-105. Alicante: Diputación Provincial de Alicante y el Centre d'Estudis Locals del Vinalopó.

GARCÍA GANDÍA, José Ramón; PÉREZ BOTí, Germán; LLORENS CAMPELLO, Sonia (2002): El yacimiento de El Secanet. Excavaciones arqueológicas en Orxeta, Alicante. Alicante: Club Universitario.

GARCÍA-GARCÍA, Marcos; MORENO-GARCÍA, Marta (2014): "De huertas y rebaños: perspectivas históricas y ecológicas sobre el papel de la ganadería en la agricultura andalusi", III Seminario Anual de la Sociedad Española de Historia Agraria (SEHA). http:// seha.info/8/3_seminario/SEHA3seminario_MarcosGarcia-GarciayMartaMoreno-Garcia.docx. [Fecha de consulta: 16/09/2021].

GARCÍA PORRAS, Alberto (2001): La cerámica del poblado fortificado medieval de "El Castillejo" (Los Guájares, Granada). Granada: Athos-Pérgamos.

GISBERT, Josep Antoni; BURGUERA, Vicent; BOLUFER, Josep (1995): "El registro cerámico de una ciudad árabe durante el primer tercio del siglo XIII. El arrabal de Daniya: El Fortí Dénia-Alacant", Actes du Vè Colloque sur la céramique médiévale en Méditerranée occidentale, pp. 162-177. Rabat: Institut National des Sciences de l'Archéologie et du Patrimoine.

GONZÁLEZ PRATS, Alfredo (1995): "Excavaciones de 1988 en el asentamiento islámico de la Font Voltá (Ares de Maestrat, Castellón)", Quaderns de prehistòria i arqueologia de Castelló, 16, pp. 235-244.

GUICHARD, Pierre (1976): Al-Andalus: Estructura antropológica de una sociedad islámica en Occidente. Barcelona: Barral. 
GUICHARD, Pierre (1990): Les musulmans de Valence et la reconquête (Xlè-XIllè siècles), 2 vol. Damasco. Traducido al español (2001): Al-Andalus frente a la conquista cristiana. Los musulmanes de Valencia (siglos XI-XIII). Madrid: Universitat de València.

GUTIÉRREZ LLORET, Sonia (2012): "Gramática de la casa. Perspectivas de análisis arqueológico de los espacios domésticos medievales en la península ibérica (siglos VII-XIII)", Arqueología de la Arquitectura, 9, pp. 139-164. https://doi. org/10.3989/arqarqt.2012.11602

GUTIÉRREZ LLORET, Sonia (2015): "Casa y casas: reflexiones arqueológicas sobre la lectura social del espacio doméstico medieval", en Mª Elena Díez y J. Navarro (eds.), La casa medieval en la península ibérica, pp. 17-48. Madrid: Sílex.

GUTIÉRREZ LLORET, Sonia (2018): "De Madīnat al-Turāb a Balansiya: ceràmica paleoandalusí a València (segles VIII-IX)", en P. Armengol Machí (coord.), L'argila de la mitja lluna: la ceràmica islàmica a la ciutat de València: 35 anys d'arqueologia urbana: [exposició], Museu d'Història de València, pp. 41-61. Valencia: Ayuntamiento de Valencia.

HERVÁS, Miguel Ángel; RETUERCE, Manuel (2005): "La medina de Calatrava la Vieja en el s. XIII. Una primera aproximación”, Arqueología y Territorio Medieval, 12.2., pp. 147-188. https://doi. org/10.17561/aytm.v12i2.1713

IZQUIERDO BENITO, Ricardo (1999): "Nuevas formas cerámicas de Vascos", Arqueología y Territorio Medieval, 6, pp. 191-206. https:// doi.org/10.17561/aytm.v6i0.1532

JIMÉNEZ CASTILLO, Pedro (2013): Murcia. De la Antigüedad al Islam. (Tesis doctoral). Granada: Universidad de Granada. Recuperado de: http://digital.csic.es/handle/10261/95860

JIMÉNEZ CASTILLO, Pedro; NAVARRO PALAZÓN, Julio (1997): Platería 14. Sobre cuatro casas andalusies y su evolución (siglos X-XIII). Murcia: Centro de Estudios Árabes y Arqueológicos "Ibn Arabí".

JIMÉNEZ CASTILLO, Pedro; PÉREZ ASENSIO, Manuel (2018): "Cerámicas emirales y califales de Murcia, calle Pascual (siglos IX-XI)", Arqueología y Territorio Medieval, 25, pp. 67-106. https://doi. org/10.17561/aytm.v25.3

JIMÉNEZ CASTILLO, Pedro; SIMÓN GARCÍA, José Luis (2017): "El poblamiento andalusí en las tierras de secano: el área sudoriental de La Mancha (ss. XI-XIII)", Al-Qantara, XXXVIII 2, pp. 215-259. https://doi.org/10.3989/alqantara.2017.008

JIMÉNEZ CASTILLO, Pedro; SIMÓN GARCÍA, José Luis (2020): "El hișn de Almansa (Albacete): fortificaciones y poblamiento", en J. Navarro Palazón y L. García-Pulido (eds.), Defensive Architecture of the Mediterranean. Vol X, pp. 105-122. Granada: UGRIUPVIPAG. https://doi.org/10.4995/FORTMED2020.2020.11551

JIMÉNEZ PUERTAS, Miguel; CARVAJAL LÓPEZ, José Cristóbal (2011): "Opciones sociotécnicas de regadío y de secano. El caso de la Vega de Granada”, Els espais de secà. IV Curs internacional d'Arqueologia Medieval, pp. 51-85. Lérida: Pagès.

KIRCHNER, Helena (2020): "La arqueología del campesinado en época alto-medieval. Reflexiones y propuestas", Imago Temporls. Medium Aevum, XIV, pp. 462-497.
LÓPEZ ELUM, Pedro (1994): La alquería islámica en Valencia. Estudio arqueológico de Bofilla. Siglos XI a XIV. Valencia: Generalitat de Valencia.

MADOZ, Pascual (1847): Diccionario geográfico-estadístico de España y sus posesiones de Ultramar. Madrid: Est. Literario-Tipográfico de L. Sagisti.

MALALANA UREÑA, Antonio; MORÍN DE PABLOS, Jorge (2013): "Dos asentamientos rurales en el territorio de Fahs al-luŷŷ de la madina de Toledo (siglos X-XI): Villajos (Campo de Criptana) y Arroyo Valdespino (Herencia)", en J. Jiménez Ávila, M. Bustamante-Álvarez y M. García Cabezas (coords.), VI Encuentro de Arqueología del Suroeste Peninsular, pp. 2003-2028. Villafranca de los Barros: Ayuntamiento de Villafranca de los Barros.

MALPICA CUELLO, Antonio (2012): "La vida agrícola y la ganadería en al-Andalus y en el reino nazarí de Granada", en R. Marín (coord.), Homenaje al Profesor Dr. D. José Ignacio Fernández de Viana y Vieites, pp. 213-228. Granada: Universidad de Granada.

MENÉNDEZ FUEYO, José Luis (2004): "La cerámica de la rábita califal", en R. Azuar Ruiz (coord.), El ribat califal. Excavaciones yestudios (1984-1992), pp. 89-130. Madrid/Alicante: Casa Velázquez, MARQ.

MUÑOZ LÓPEZ, Francisco; CASTAÑO BLÁZQUEZ, Trinidad (1993): "El alfar islámico de la calle Pedro de la Flor", Verdolay, 5, pp. 157-169.

NAVARRO PALAZÓN, Julio (1986): La cerámica islámica en Murcia. I Catálogo. Murcia: Ayuntamiento de Murcia.

NAVARRO PALAZÓN, Julio; JIMÉNEZ CASTILLO, Pedro (2007): Siyāsa. Estudio arqueológico del despoblado andalusí (ss. XI-XIII). Murcia: El Legado Andalusí.

NAVARRO PALAZÓN, Julio; ROBLES FERNÁNDEZ, Alfonso (1996): Liétor. Formas de vida rurales en Shara al-Andalus a través de una ocultación de los siglos X-XI. Murcia: Ayuntamiento de Murcia.

NAVARRO ROMERO, Carmen (1998): "Fortificaciones y asentamientos andalusíes en la actual provincia de Albacete: un Al-Andalus textualmente casi invisible", en M. Barceló y P. Toubert (eds.), «L'incastellamento", Actas de las reuniones de Girona y Roma, 1992 y 1994, pp. 205-231. Roma: L'École Française de Rome.

NEGRE, Joan; LOZANO, Luis; SELMA, Sergi (2018): "Una primera aproximació a la caracterizació de la ceràmica andalusina de la fortalessa d'Orpessa (Castelló)", Quaderns de prehistòria i arqueologia de Castelló, 36, pp. 231-256.

ORTEGA ORTEGA, Julian; VILLARGORDO ROS, Carolina (2020): "Campesinos ricos en al-Ándalus? Comunidades rurales, estratificación interna y formas de consumo en la alquería de El Quemao (Sarrión, Teruel)", Actualidad de la investigación arqueológica en España I (2018-2019). Conferencias impartidas en el Museo Arqueológico Nacional, pp. 177-196. Madrid: Museo Arqueológico Nacional.

PÉREZ ASENSIO, Manuel; JIMÉNEZ CASTILLO, Pedro (2018): "El ajuar cerámico almorávide en Šarq al-Andalus", en M. Marcos Cobaleda (ed.), Al-Murābițūn (los almorávides): un Imperio islámico occidental. Estudios en memoria del Profesor Henri Terrasse, pp. 161-221. Granada: Patronato de la Alhambra y Generalife. 
PÉREZ BOTÍ, Germán (2014): "La caracterización de la cerámica islámica de El Castellar de Alcoi (Alicante) de finales del siglo IX y siglo X: El Horizonte Castellar l', Recerques del Museu d'Alcoi, 22/23, pp. 53-68.

PONCE HERRERO, Gabino (1989): El Corredor de Almansa: estudio geográfico: Albacete: Instituto de Estudios Albacetense "Don Juan Manuel".

POZO MARTínEZ, Indalecio (2000): "La alquería islámica de Villa Vieja (Calasparra, Murcia)", en E. Hubert y A. Bazzana (coords.), Castrum 6. Maisons et espaces domestiques dans le Monde Méditerranéen au Moyen Âge, pp. 165-175. Roma-Madrid: Collection de la Casa de Velázquez.

PRETEL MARÍN, Aurelio (1992): Chinchilla medieval. Albacete: Instituto de Estudios Albacetense "Don Juan Manuel".

RAMÍREZ, Esperanza; IDÁÑEZ, José Félix (1988): "Cerámica islámica de la provincia de Albacete", Actas del I Congreso de Historia de Castilla-La Mancha. Tomo V, pp. 73-83. Toledo: Junta de Comunidades de Castilla La Mancha.

REKLAITYTE, leva (2005): "El saneamiento en las ciudades andalusíes", Anales de Arqueología Cordobesa, 16, pp. 207-238.

RETAMERO SERRALVO, Félix (2011): "Pautes per a l'estudi dels conreus de secà a Alandalús", en F. Sabaté, y J. Brufal (eds.), Els espais de secà. IV Curs internacional d'Arqueologia Medieval, pp. 31-49. Lérida: Àgira.

ROSSELLÓ BORDOY, Guillermo (1975): "La cerámica árabe en Mallorca: avances sobre su tipología y cronología”, Mayurqa: revista del Departament de Ciències Històriques i Teoria de les Arts, 14, pp. 215-230.

ROVIRA, Jordi; CASANOVAS, Àngels; GONZÁLEZ, Joan R.; RODRÍGUEZ, Josep I. (1997): "Solibernat (Lleida). Un asentamiento rural islámico con finalidades militares de la primera mitad del siglo XII", Archéologie islamique, 7, pp. 93-110.

RUBIERA MATA, María Jesús (1987): "Los precedentes geopolíticos musulmanes del Señorío de Villena”, Congreso de Historia del Señorío de Villena, pp. 357-360. Albacete: Instituto de Estudios Albacetense "Don Juan Manuel".

RUBIO GOMIS, Federico (1989): "Memoria sobre el yacimiento medieval del Sompo, Cocentaina (Alicante)", Archivo de Prehistoria Levantina, 19, pp. 385-409.

SABATÉ, Flocel y BRUFAL, Jesús (eds.) (2011): Els espais de secà. IV Curs internacional d’Arqueologia Medieval. Lérida: Àgira.

SALVATIERRA CUENCA, Vicente; CASTILLO ARMENTEROS, Juan Carlos (1995): "Peñaflor, un établissement rural d'époque émirale dans la campiña de Jaén”, Archéologie Islamique, 5, pp. 11-24.

SALVATIERRA CUENCA, Vicente; CASTILLO ARMENTEROS, Juan Carlos (2000): Los asentamientos emirales de Peñaflory Miquelico (Jaén): Proyecto "El poblamiento hispano-musulmán de Andalucía Oriental. La Campiña de Jaén (1987-1992)". Sevilla: Consejería de Cultura.
SÉNAC, Philippe; GASC, Sébastien; GIBERT, Jordi; SAVARESE, Laurent (2020): Un habitat rural d'al-Andalus (Xe-Xle siècles). Les fouilles de Las Sillas (Marcén, Huesca). Madrid: Casa de Velázquez.

SIMÓN GARCÍA, José Luis (2010): "El poblamiento islámico en el Corredor de Almansa y las tierras de Montearagón: Los andalusíes olvidados", XVI Jornadas de Estudios Locales, pp. 169-266. Almansa: Ayuntamiento de Almansa.

SIMÓN GARCÍA, José Luis (2011): Castillos y torres de Albacete. Albacete: Instituto de Estudios Albacetenses "Don Juan Manuel".

SIMÓN GARCÍA, José Luis (2013): "Del hisn al-Karas al castrum de Alcaraz: una aproximación desde la arqueología", en A. Petrel Marín (coord.), Alcaraz: del Islam al concejo castellano, pp. 55-76. Alcaraz: Ayuntamiento de Alcaraz e Instituto de Estudios Albacetenses "Don Juan Manuel".

SIMÓN GARCÍA, José Luis (2014a): "El poblamiento islámico en Albacete. Las alquerías andalusíes del Villar de Hoya Honda y la Graja (Higueruela, Albacete)", Al-Basit, 59, pp. 191-252.

SIMÓN GARCÍA, José Luis (2014b): "El poblamiento islámico de las tierras de Alcalá del Júcar (siglos VIII al XIII)", Alcalá del Júcar: piedra, tierra, agua y sus gentes, pp. 53-84. Albacete.

SIMÓN GARCÍA, José Luis (2017): "El poblamiento islámico de Villamalea y la margen derecha del Cabriel (Albacete)", en J. Cano Valero (coord.), Villamalea: retazos de historia y de la vida de sus gentes, pp. 41-78. Albacete: Instituto de Estudios Albacetenses "Don Juan Manuel".

SIMÓN GARCÍA, José Luis; HERNÁNDEZ CARRIÓN, Emiliano (2013): "Trashumancia y arquitectura de piedra en seco en Albacete", Zahora, 57, pp. 67-89.

SIMÓN GARCÍA, José Luis; SIMÓN OLIVER, Fernando (2018): "Aguay poblamiento en el Sureste”, Murgetana, 138, pp. 101-132.

TRILLO SAN JOSÉ, Carmen (2004): Agua, tierra y hombres en al-Andalus. Granada: Ajbar.

'UDRĪ (al-), Ahmad b. Umar, Tarșī' (1965): Nusūs 'an al-Andalus min kitāb Tarșī'a lajbār. Ed. 'A. 'A. al-Ahwānī. Madrid: Instituto Egipcio de Estudios Islámicos. Trad. parcial y estudio en MOLINA E. (1972): La cora de Tudmir según al-'Udrī (s. XI). Aportaciones al estudio geográfico-descriptivo del SE peninsular. Cuadernos de Historia del Islam, IV, vol. Monográfico. Granada: Seminario de Historia del Islam de la Universidad de Granada.

WALTZ, Pierre (1900): "Trois villes primitives nouvellement explorées (Los Castillares, Los Altos de Carcelén, Las Grajas)", Bulletin Hispanique, 3, t. (2), pp. 153-160. https://doi.org/10.3406/ hispa.1900.1221

ZOZAYA, Juan (coord.) (1995): Alarcos'95. El fiel de la balanza. Ciudad Real: Junta de Comunidades de Castilla La Mancha. 